\title{
THE GENUS FISSIDENS (FISSIDENTACEAE, BRYOPHYTA) IN HUNGARY
}

\author{
Peter ERZBERGER
}

Belziger Str.37,D-10823 Berlin, Germany; erzberger.peter@gmail.com

Erzberger, P. (2016): The genus Fissidens (Fissidentaceae, Bryophyta) in Hungary. - Studia bot. bung. 47(1): 41-139.

\begin{abstract}
All available specimens of Fissidens collected in Hungary and deposited in BP, and the Hungarian collections of the author (B-Erzberger) were revised, altogether more than 1500 specimens. These collections are representative of Hungary, therefore their revision is equivalent to the evaluation of Fissidens in Hungary. As a result of this work, the following sixteen taxa were found to occur in Hungary: $F$. adianthoides, $F$. arnoldii, F. bambergeri, F. bryoides, $F$. crassipes, $F$. crispus $(=F$. limbatus), F. curvatus ( $F$. algarvicus), F. dubius, F. exiguus, F. exilis, F. gracilifolius, F. gymnandrus, $F$. incurvus, F. pusillus, F. taxifolius, and F. viridulus. F. bambergeri and F. crispus are reported for the first time in Hungary. F. crassipes subsp. warnstorfi is no longer distinguished from $F$. crassipes subsp. crassipes, and $F$. bryoides var. caespitans $(=F$. curnovii) is excluded. There are doubts with respect to the taxonomic value of $F$. bambergeri and $F$. exiguus, but these seem insufficient at present to warrant future neglection of these taxa. All Hungarian species are illustrated and described in detail, with notes on habitat and associated bryophytes; their records are shown in a map, and their red list status is briefly discussed. In addition, descriptions are also provided for all Fissidens species occurring in the countries surrounding Hungary (but not in Hungary: F. fontanus, F. osmundoides, $F$. ovatifolius, F. rivularis, F. rufulus, F. serrulatus). These species are also included in the key, and some of them are illustrated.
\end{abstract}

Key words: distribution maps, habitat requirements, illustrated key, morphological descriptions, mosses

\section{INTRODUCTION}

Revision of old Hungarian bryophyte specimens of some large or critical genera (Bryum: ERzBerger and Schröder 2013, Grimmia: Erzberger 2009, Schistidium: ERZBERGER and SCHRÖDER 2008, Racomitrium: ERZBERGER et al. 2016) has proved to be both rewarding and necessary in four respects: (i) amendment of the Hungarian checklist was achieved by adding species new to the country that were detected in the old collections, and by exclusion of others that were not substantiated by correct vouchers; (ii) the detailed distribution of species in the country could be clarified, since literature reports were in part based on misidentified specimens; (iii) conclusions concerning the ecological behaviour of species, which were based on erroneous distributional data could also be amended; 
and finally, (iv) revision furnished solid data needed for improved red list assessments. In the present paper, this approach is applied to the genus Fissidens Hedw.

The most recent checklist of Hungarian bryophytes (PAPP et al. 2010) and its predecessor (ERZBERGER and PAPP 2004) list 16 taxa in the genus Fissidens. Whereas the European species of subgenera Aloma Kindb. and Pachyfissidens (Müll. Hal.) Kindb. seem less problematic as far as species circumscription and taxonomy are concerned, this cannot be said of subgenus Fissidens, comprising species with in general bordered (limbate) leaves.

There is considerable disagreement between North American and European bryologists concerning e.g. F. bryoides Hedw. (Bruggeman-Nannenga in Hill et al. 2006). PURSELL (2007) considers Fissidens bryoides "a veritable kaleidoscope of intergrading expressions" and consequently includes in its synonymy several names of taxa traditionally distinguished by European authors from $F$. bryoides s. str.: F. pusillus (Wilson) Milde, F. viridulus (Sw.) Wahlenb., F. bryoides var. incurvus (Starke) Huebener, F. exiguus Sull. In the European checklist (HILL et al. 2006) some of these are recognised at specific or subspecific rank, e.g. F. pusillus (Wilson) Milde, F. viridulus (Sw. ex anon.) Wahlenb. var. viridulus, F. viridulus var. incurvus (Starke ex Röhl) Waldh. Other taxa appearing in the Hungarian checklist (ERZBERGER and PAPP 2004) or distinguished by some European treatments are no longer recognised in HiLl et al. (2006): F. exiguus and F. bambergeri Milde are considered "(probably) just poorly limbate forms of limbate species” (Bruggeman-Nannenga in Hill et al. 2006). F. warnstorfii M. Fleisch. $(=F$. crassipes subsp. warnstorfii (M. Fleisch.) Brugg.-Nann.) is no longer recognised as different from $F$. crassipes Wilson ex Bruch et Schimp. subsp. crassipes in the recent treatment for the Iberian Peninsula (Guerra and EDERra 2015). Different taxonomic views are also reflected by the fact that some taxa are treated at different ranks by different authors, e.g. F. gymnandrus Büse and F. curnovii Mitt. are often treated as varieties of F. bryoides (GUERRA and EDERRA 2015).

Another point of disagreement between North American and European concepts concerns F. crispus Mont. Pursell (2007) includes F. limbatus Sull. in $F$. crispus, but recognises F. minutulus Sull. as distinct, whereas BruggemanNannenga in Hill et al. (2006) is not convinced that the two taxa, F. crispus and F. minutulus, are distinct in Europe and therefore treats them as synonyms.

Finally, there appear to be serious differences in taxon circumscription by different authors, or else it must be assumed that some species have very different ecological affinities in the British Isles than on the continent. This concerns e.g. the species pair F. pusillus and F. gracilifolius Brugg.-Nann. et Nyholm. According to NyHolm (1987), Ahrens (2000), and Meinunger and Schöder (2007), F. gracilifolius grows on moist shaded calcareous rocks, whereas $F$. pusillus is restricted to siliceous rocks in or near streams. SMITH (2004) and Blockeel 
in BLOCKEEL et al. (2014: 4) agree with continental authors on the calciphilic nature of $F$. gracilifolius, but on the other hand state that $F$. pusillus "occurs both on basic rocks such as limestone, and others that are neutral to mildly acid, like sandstone and granite" (Blockeel in BLOCKEEL et al. 2014: 3).

A quick glance at the labels of herbarium specimens in the bryophyte collection of the Hungarian Natural History Museum (BP) inserted in F. gracilifolius and F. pusillus, respectively, shows that under both names collections from limestone as well as collections from volcanic areas can be found. This is probably owed at least in part to the concepts in ORBÁN and VAJDA (1983: 267) who state that F. pusillus (as F. minutulus Sull.) occurs "mainly on andesite and limestone", whereas "F. minutulus var. tenuifolius Norkett (syn. F. pusillus var. minutulus Sull.) ... occurs mainly on moist limestone". The situation is obviously aggravated by an entangled nomenclature (CORLEY 1980).

In order to clarify some of the problems outlined, a revision of all specimens of Fissidens deposited in BP and collected in present-day Hungary and of specimens in the author's herbarium (B-Erzberger) was undertaken, which is also a contribution to the evaluation of existing collections for the ongoing Hungarian bryophyte recording project (ERZBERGER 2012). Field data from this project were included in particular for frequent species like $F$. dubius and $F$. taxifolius.

The following questions were addressed:

- Which taxa form part of the Hungarian bryoflora?

- What is their distribution in the country?

- What can be concluded on their habitat preferences?

It was my aim to summarise the descriptions of taxa as understood by most present authors, and to apply these morphological concepts to the Hungarian collections. The results should also serve as a tool for further (field) research, therefore the list of taxa treated has been extended to include all species that occur in any of the countries surrounding Hungary. Apart from the descriptions, a key and illustrations are provided. Finally, some amendments to the red list status of the taxa are considered.

\section{MATERIAL AND METHODS}

All available specimens of Fissidens collected in present-day Hungary and deposited in the bryophyte collection of the Hungarian Natural History Museum (BP), including the rich bryophyte herbarium of Ádám Boros (curated separately in BP), and the Fissidens specimens of the author's herbarium (in B) collected in Hungary were revised, in total more than 1500 specimens. These include, however, numerous duplicates. 
Illustrations of individual species were prepared using Leitz and WildHeerbrugg drawing apparatus. All plants illustrated are from Hungarian collections unless stated otherwise in the captions. Distribution maps showing records substantiated by vouchers seen by the author are based on the Central European grid (NIKLFELD 1971). Maps of clearly recognisable species are complemented by recent observations without vouchers. Open and closed circles represent collections before and after 1973 (the year of Ádám Boros's death), respectively. In those cases where "old" and "recent" data were available for the same grid cell, only the recent data are shown in the map (i.e. "recent" overwrites "old"). For some specimens the collection site could not be assigned unambiguously to a grid cell. These data have been omitted from the maps.

Nomenclature of bryophytes follows the Hungarian checklists in current use (Erzberger and PAPp 2004, PAPp et al. 2010), except for taxa not contained, and $F$. bryoides var. caespitans ( $=F$. curnovii), where HILl et al. (2006) is followed. F. crassipes subsp. warnstorfii is included in F. crassipes following GUERRA and EDERRA (2015), therefore the name F. crassipes subsp. crassipes is replaced by F. crassipes in this paper.

Terminology in the key and descriptions is based mainly on MAGILL (1990) with some exceptions detailed below.

For the occurrence of Fissidens species in countries adjacent to Hungary, the following references were consulted: HodgetTs (2015), Ignatov et al. (2006), KöCKINGER et al. (2011), KUBINSKÁ et al. (2001), MARTINČIČ (2003, 2016), Ros et al. (2013), ŞTEFĂNUȚ and GoIA (2012). Red list status in these countries was adopted from HodGETTS (2015), as was also the status of a candidate for the new European red list. The categories of the old European red list (ECCB 1995) are also given.

Selected taxonomic characters (arranged in the same order as in the descriptions)

Size

The size of the gametophyte, measured as the length of the shoot, varies between $1 \mathrm{~mm}$ and $15 \mathrm{~cm}$. Small plants only a few millimetres long are observed in F. exilis, F. curvatus, F. bambergeri, F. exiguus, F. arnoldii, F. crispus, F. ovatifolius, F. gracilifolius, F. pusillus, F. viridulus. The longest shoots, ranging from 1 to several centimetres, are observed in species of subgenus Pachyfissidens: F. adianthoides, F. dubius, F. serrulatus, F. osmundoides, F. taxifolius, and subgenus Octodiceras: F. fontanus. Among the limbate species of intermediate size F. crassipes, F. rivularis, F. bryoides var. bryoides, and var. caespitans are usually somewhat larger than $F$. incurvus or F. gymnandrus. 
Sterile stems are often longer than fertile shoots, and plants from caves can produce long shoots with many leaf pairs. Very long, many-leaved shoots also occur in aquatic plants like F. fontanus, F. crassipes, F. rufipes.

\section{Stem}

The stem has a well differentiated central strand in $F$. taxifolius and the other species of subgenus Pachyfissidens (F. adianthoides, F. dubius, F. osmundoides, $F$. serrulatus), whereas in the small species of subgenus Fissidens (F. exilis, F. gracilifolius, F. pusillus, F. bambergeri, F. curvatus, F. crispus, F. viridulus, F. exiguus) it is often hardly differentiated. Exceptions are F. bryoides, F. gymnandrus, F. incurvus, F. ovatifolius and the more robust species like F. crassipes, F. rivularis and F. rufulus, where a central strand is present. It is completely lacking in F. fontanus.

\section{Rhizoids}

Rhizoids are usually confined to the base of stems; in most species they are brown (sometimes reddish brown: F. serrulatus; hyaline to light-brown in $F$. exilis; often - but not always - purplish-red in F. bryoides var. caespitans), and \pm smooth. An exception is $F$. osmundoides, where some rhizoids are papillose, in particular those of 10-20 $\mu \mathrm{m}$ diameter. Slightly papillose rhizoids have been reported to occur sometimes in $F$. bryoides, $F$ crassipes, $F$. crispus, $F$. curvatus, $F$. exilis, F. gracilifolius, F. osmundoides, F. ovatifolius, F. pusillus, F. rivularis, $F$. rufulus, F. taxifolius, F. viridulus (Guerra and Ederra 2015).

\section{Leaf}

The genus Fissidens is characterised by leaves of a particular form that are arranged in a single plane, i.e. in two rows along the stem, and are half-clasping the stem and the following leaf towards the stem tip. Each leaf usually consists of three different parts: (i) the boat-shaped or sheathing part, named the vaginant laminae (also called lamina vera, but interpretation of the different parts of the Fissidens leaf is still controversial: BEEVER et al. 2002); (ii) the ventral lamina, the part of the leaf apical or distal to the vaginant laminae, on the adaxial side of the costa, and (iii) the dorsal lamina, the part of the leaf blade opposite the sheathing base and the ventral lamina, occupying the total length of the leaf on the abaxial side or back of the costa (PURSELL 2007). However, this terminology is not universally accepted. Some authors (e.g. CRUM and ANDERSON 1981) use the term apical lamina instead of ventral lamina and define it as the part of the leaf apical to the vaginant laminae on both sides of the costa. I will also make use of this term. The definition of the dorsal lamina is sometimes understood as 
confined to the lower part opposite the vaginant laminae (MAGILL 1990: "part of the leaf blade opposite the sheathing base, at the back of the costa and below the apical lamina"). This must be kept in mind when comparing descriptions in different treatments.

The ventral and dorsal laminae may not be fully developed in dwarf male plants or in lower cauline leaves.

The apical and the sheathing part of the leaf are mostly of nearly equal length, but there is rather great variability in this respect; lower leaves tend to have smaller apical parts. Some species have characteristic proportions: the apical part is significantly longer than the sheathing part in $F$. fontanus and in the upper leaves of $F$. exilis, and significantly shorter in $F$. bambergeri and $F$. rufulus, mostly shorter in F. adianthoides, F. dubius, and $F$. taxifolius.

The dorsal lamina usually terminates at leaf insertion, or may even be decurrent along the stem, but sometimes ends above the leaf base. This, also, is a variable character (CORLEY 1980), but an incomplete dorsal lamina is usually found in F. ovatifolius, F. bambergeri, F. exilis, and F. fontanus.

\section{Leaf margin}

Another key feature of the Fissidens leaf is the margin. This can either be formed by a border called the limbidium, of long, narrow, incrassate cells, or, in the absence of such a border, by one to several rows of cells that differ from adjacent laminal cells in some characters, e.g. size or wall thickness, and form a \pm conspicuous marginal band. Leaves (and plants with such leaves), which possess a limbidium are called limbate, those without limbidium are called elimbate. Among the species treated in this account, limbate taxa are found in subgenus Fissidens, whereas elimbate plants occur in subgenera Pachyfissidens and Octodiceras.

The limbidium can be developed to a very variable extent, even within a given population. It usually occurs on all three laminae in limbate species except in $F$. arnoldii, F. bambergeri and $F$. exiguus, where it is restricted to the vaginant laminae, in F. arnoldii and F. exiguus often on perichaetial leaves only. But there are all kinds of transitional forms with the limbidium variously reduced, in particular in the dorsal lamina and towards the base.

The limbidium is particularly well developed in F. crassipes, F. rivularis, and F. rufulus, where it forms a 2-4-stratose conspicuous, bulging, often coloured border.

A unistratose limbidium is found in F. gracilifolius and F. pusillus; in F. bryoides, F. ovatifolius, and F. crispus the limbidium is unistratose to bistratose, and in F. curvatus, F. crassipes, F. rufulus, and F. rivularis the limbidium is at least bistratose, tri- to tetrastratose in $F$. rivularis. 
In the sheathing part the limbidium sometimes enters the lamina, i.e. the border cells are separated from the margin by a row of chlorophyllose, quadrate cells. This is called an intralaminar or intramarginal limbidium. It is particularly frequent in F. bambergeri and F. crassipes, but not rare in other species as well (e.g. F. ovatifolius, F. crispus, F. viridulus). It is not observed in $F$. bryoides, F. curvatus, $F$. gracilifolius, $F$. pusillus, $F$. rivularis, $F$. rufulus (sometimes weakly differentiated).

\section{Leaf apex}

Taxa differ significantly in the structure of the leaf tip. The limbidium ceases below the apex in F. crassipes, F. pusillus, F. gracilifolius, F. viridulus, F. ovatifolius and $F$. rufulus; it is confluent with the costa at the leaf apex in F. bryoides var. bryoides, F. bryoides var. caespitans, F. rivularis, F. crispus, F. curvatus, and sometimes in F. gymnandrus and F. incurvus. The costa may cease below the apex, or be percurrent to excurrent. In the latter case it may form a mucro, sometimes together with the limbidium, e.g. in F. rivularis and F. bryoides var. caespitans.

\section{Costa}

The anatomy of the costa is important for the differentiation of subgenera and sections (BRUGGEMAN-NANNENGA 1990), but not useful for the species considered here. The strongest costae are found in the large species, $F$. serrulatus (70-120 $\mu \mathrm{m}$ wide at mid leaf), $F$. adianthoides, and F. dubius. In F. crassipes, $F$. rivularis, and $F$. rufulus, the costa is also very stout, as is the limbidium, perhaps an adaptation to flowing water.

\section{Leaf stratosity}

In most cases the lamina is unistratose, but in $F$. dubius (and in F. serrulatus) it is usually partially bistratose, in F. crispus occasionally. Leaves of F. rufulus are pluristratose at the base of the dorsal lamina, and those of $F$. rivularis are sometimes partially bistratose at the base near the costa. F. adianthoides may also rarely have bistratose spots near the costa.

\section{Leaf cells}

Leaf cells are mostly isodiametric, irregularly to regularly (in particular in F. bryoides) hexagonal to oblong, ca twice as long as wide in F. curvatus. Some species have cells that are \pm bulging (seen in cross section), e.g. F. dubius (except marginal rows) and F. crispus. Leaf cells are plane to slightly bulging in $F$. ovatifolius, and mamillose in F. taxifolius (in particular outside of vaginant laminae) and F. serrulatus. 
It is important to realise that even if every laminal cell has one centrally placed mamilla, in cross section not every cell will appear mamillose, since not every cell will be sectioned across the centre due to the hexagonal arrangement of cells.

F. crispus has cells appearing about twice as high as wide in cross section.

Care must be taken where to measure the size of laminal cells, since different accounts give the size of laminal cells in different parts of the leaf, e.g. in the middle of dorsal lamina or in the middle of apical lamina. Some floras give the longest dimension, others differentiate between cell length and width.

The size of laminal cells is important for the distinction of several closely related species: e.g. F. dubius: $6-12(-14) \mu \mathrm{m}$, and $F$. adianthoides: (10-) 12-18 $(-20) \mu \mathrm{m} ;$ F. rufulus: (6-) 7-11 (-15) $\mu \mathrm{m}$, and F. crassipes: 9-23 (-30) $\mu \mathrm{m}$.

\section{Sexual condition}

Most species are dioicous or autoicous, this condition is not correlated with other characters. F. arnoldii is dioicous, F. bryoides usually autoicous. Synoicous inflorescences occur in $F$. crassipes and F. rufulus. F. bambergeri is polyoicous. In $F$. gymnandrus, all types of inflorescence are observed: autoicous, paroicous, synoicous or rarely dioicous.

CORLEY (1980) states there is much variability with respect to inflorescence type.

\section{Position of archegonia (seta) and antheridia}

In most species, archegonia are terminal, with the exception of $F$. adianthoides (in the middle of shoots), F. dubius (in the middle or at the base of shoots) and $F$. taxifolius (at the base of shoots). Position of antheridia is more variable: In most species they are terminal, either at the tip of fully grown plants or at dwarf male plants or branches. Lateral antheridia, usually surrounded by perigonial leaves and thus in bud-like branches occur in F. adianthoides, F. bryoides (rarely naked), F. dubius, F. gymnandrus (usually naked, rarely in perigonia), F. viridulus (usually terminal, rarely in bud-like branches at stem base).

\section{Size of gametangia}

Archegonium length: The lowest values are given for $F$. arnoldii $(200 \mu \mathrm{m}), F$. bambergeri $(180-240 \mu \mathrm{m})$, F. exilis $(180-270 \mu \mathrm{m})$; the highest values are obtained for $F$. rufulus $(300-560 \mu \mathrm{m})$ and $F$. crassipes $(420-660 \mu \mathrm{m})$.

Antheridium length: Similarly to archegonium length, the lowest values are measured in F. exilis (90-120 $\mu \mathrm{m})$, and the highest values in F. rufulus (250-400 $\mu \mathrm{m})$ and $F$. crassipes $(190-450 \mu \mathrm{m})$. 
These characters are taxonomically significant and may be used to distinguish between species, e.g. archegonia and antheridia are significantly longer in F. crassipes (420-660 $\mu \mathrm{m}$ and (190-) 260-400 (-450) $\mu \mathrm{m}$, respectively) than in $F$. pusillus (290-350 $\mu \mathrm{m}$ and ca $200 \mu \mathrm{m}$, respectively).

\section{Sporophytes}

Many species regularly produce sporophytes, e.g. F. bryoides, F. exilis, F. gracilifolius, F. pusillus, F. viridulus, F. incurvus; in other species capsules are occasional.

The shape of the capsule is important for the identification of some taxa. An erect and radially symmetric capsule is found in most species, but an inclined asymmetric capsule is observed in F. incurvus, F. bryoides var. caespitans, F. curvatus, F. crispus, and F. ovatifolius.

\section{Peristome teeth}

The structure of peristome teeth is an important taxonomic character (BRUGGEMAN-NANNENGA and BERENDSEN 1990), but mainly useful in establishing supraspecific relationships. For the species treated here, the width of the peristome teeth at their base is sometimes useful, e.g. for the distinction between large plants of $F$. pusillus and small plants of F. crassipes. However, there is wide variation in this character, e.g. F. crispus $(21-56 \mu \mathrm{m})$; the lowest values are given for $F$. gracilifolius $(24-39 \mu \mathrm{m}), F$. pusillus $(24-53 \mu \mathrm{m})$, F. exilis $(30-39 \mu \mathrm{m}), F$. arnoldii $(33-36 \mu \mathrm{m})$; the highest values for $F$. crassipes $(51-86 \mu \mathrm{m}), F$. osmundoides (to $85 \mu \mathrm{m}), F$. taxifolius $(75-90 \mu \mathrm{m}$ ) and F. dubius (to $120 \mu \mathrm{m}$ ).

\section{Spore size}

Spore size appears not to be useful in naming taxa of Fissidens, since in most species there is very wide variation, e.g. in F. crassipes $14-30 \mu \mathrm{m}$, and different accounts frequently give strongly different ranges. For F. rivularis, e.g., LIMPRICHT (1890) and Demaret and Castagne (1959) give $12 \mu \mathrm{m}$, Casas et al. (2006) 14-20 $\mu \mathrm{m}$, Cortini Pedrotti (2001) and Smith (2004) give 17-20 $\mu \mathrm{m}$.

\section{RESULTS}

Overview of listed taxa

This revision has resulted in verifying sixteen taxa as part of the Hungarian bryoflora. While the specific treatment below for practical purposes is in alpha- 
betical order, a systematic overview (following PURSell and BRUgGemanNANNENGa 2004 and Bruggeman-Nannenga in Hill et al. 2006) is given here. The taxa confirmed for Hungary are printed in bold.

Fissidens Hedw.

Subgenus Pachyfissidens

Section Pachyfissidens: F. adianthoides, F. dubius, F. osmundoides, F. serrulatus, $\boldsymbol{F}$. taxifolius

Subgenus Octodiceras: F. fontanus

Subgenus Fissidens

Section Fissidens (= Section Pachylomidium Müll. Hal.): F. arnoldii, F. bambergeri, F. bryoides var. bryoides, F. bryoides var. caespitans, F. crassipes, F. crispus (= F. limbatus), F. curvatus, F. exiguus, F. gracilifolius, F.gymnandrus, F. incurvus, F. kosaninii (= F. valiae), F. ovatifolius, $F$. pusillus, F. rivularis, F. rufulus, $F$. viridulus

Subgenus Aloma: F. exilis

Key to Fissidens

(including taxa known from countries adjacent to Hungary)

Whereas determination of elimbate species (i.e. species in subgenera Octodiceras, Pachyfissidens, and Aloma of this account) is straight-forward, determination of limbate species (subgenus Fissidens) is often problematic due to overlapping and sometimes variable characters. The most important characters separating individual species in this group are:

- limbidium: lacking on part of laminae (F. bambergeri, F. exiguus); ceasing below apex (F. crassipes, F. gracilifolius, F. pusillus); often intralaminar in vaginant laminae (F. bambergeri, F. crassipes); conspicuously strong, bulging, multistratose (F. crassipes, F. rufulus, F. bryoides var. caespitans);

- sexual condition, position of antheridia: antheridia in bud-like axillary perigonia ( $F$. bryoides var. bryoides, F. bryoides var. caespitans, F. curnovii, F. rivularis); antheridia naked in leaf axils ( $F$. gymnandrus); antheridia terminal in dwarf or larger male plants or shoots (F. viridulus, F. incurvus, F. ovatifolius);

- cell size: particularly small cells are found in F. crispus, F. ovatifolius, $F$. rufulus;

- cell shape: isodiametric in most species, but ca twice as long as wide in $F$. curvatus; \pm bulging in F. crispus, F. taxifolius, and F. ovatifolius; ca twice as high as wide (cross section) in F. crispus;

- capsule shape: asymmetric and inclined in F. bryoides var. caespitans and F. incurvus. 
1a Leaves with a border of elongate cells (limbidium), at least in sheathing part of lamina, in $F$. exiguus only in perichaetial leaves

Note: F. arnoldii, which has elongate marginal cells resembling a border on the sheathing part of perichaetial leaves, is keyed out in both alternatives

$1 \mathrm{~b}$ Leaves without a border of elongate cells 18

2a Laminal cells twice as long as wide; plants 1-3 mm long with 3-5 pairs of leaves; leaves narrowly lanceolate, tapering to apex from below middle; terricolous ........... F. curvatus $(=F$. algarvicus)

Has been found only once in Hungary; DD-va (PAPP et al. 2010)

2b Laminal cells as long as wide; leaves tapering only at apex .... 3

3a Limbidium mostly confined to sheathing part of perichaetial leaves, sometimes variously reduced on cauline leaves

4

$3 \mathrm{~b}$ Limbidium well developed on all laminae and all leaves except sometimes the lowermost ... 6

4a Plants terricolous, growing in base-rich, often dry habitats; limbidium often intramarginal in sheathing part of leaf; dorsal lamina not reaching the stem; plants polyoicous, often with a terminal synoicous inflorescence

F. bambergeri

$4 \mathrm{~b}$ Plants growing on rock or stones in or near water ... 5

5a Apex rounded to obtuse, cells below apex often in concentric rows; margin slightly crenulate by protruding cell ends; plants growing on limestone or other base-rich rock in or near water

$F$. arnoldii

5b Apex acute; margin entire; plants growing on moist sandstone or volcanic rock near water ... F. exiguus

6a Leaf cells conspicuously small, usually not longer than $8 \mu \mathrm{m}$ and not wider than $6 \mu \mathrm{m}$.......... 7

$6 \mathrm{~b}$ Leaf cells not conspicuously small, usually larger ................................................................. 8

7a Dorsal lamina not reaching leaf base; leaves broad ovate-elliptic to broad oblong, $<2.5$ times as long as wide; median laminal cells not or only slightly protuberant, as high as wide in transverse section

F. ovatifolius

$7 \mathrm{~b}$ Dorsal lamina usually extending to the leaf base; leaves oblong to ovate-lanceolate, $>2.5$ times as long as wide, median laminal cells distinctly protuberant on both sides, higher than wide (transverse section)

8a Limbidium confluent with excurrent or percurrent costa; antheridia often in bud-like perigonia or naked in leaf axils

8b Limbidium not confluent with costa; antheridia not axillary ............................................... 13

9a Antheridia terminal in dwarf male plants; capsule asymmetric, strongly inclined ... F. incurvus

9b Antheridia axillary, not in dwarf male plants; capsule inclined or erect ............................... 10

10a Limbidium (12-) 20-30 (-40) $\mu \mathrm{m}$ wide on dorsal lamina; costa excurrent in stout mucro to $150 \mu \mathrm{m}$ long, pluristratose in its proximal part F. rivularis

10b Limbidium 7.5-12.5 (-14) $\mu \mathrm{m}$ wide on dorsal lamina; costa percurrent or at most shortly excurrent ( $\boldsymbol{F}$. bryoides s. 1.)

11a Antheridia nearly always naked in leaf axils; plants mostly growing on periodically inundated, silt-covered tree trunks or roots (rarely also rocks or stones, in other European countries often on silt-covered stones of embankment along great rivers) F. gymnandrus

$11 \mathrm{~b}$ Antheridia in axillary bud-like perigonia, rarely naked 12 Rhizoids often purplish red, but sometimes brown; capsules inclined; plants growing on acidic soil or rock near water F. bryoides var. caespitans

12b Rhizoids brown; capsules erect; plants growing on moist loamy soil usually away from water F. bryoides var. bryoides

13a Limbidium bi- to pluristratose on vaginant laminae; costa ceasing below leaf apex; laminal cells $10-18 \mu \mathrm{m}$ in diameter; plants $5-30 \mathrm{~mm}$ long, on rocks along rivers and streams $(\boldsymbol{F}$. crassipes complex) 
13b Limbidium 1-2-stratose on vaginant laminae; plants often $<5 \mathrm{~mm}$ long, terrestrial or aquatic .. 15

14a Median laminal cells 6-12 (-15) $\mu \mathrm{m}$ long; sheathing part usually without intramarginal limbidium; predominantly on acidic rock substrates in clean water F. rufulus

14b Median laminal cells (10-) 12-18 (-20) $\mu \mathrm{m}$ long; sheathing part often with intramarginal limbidium; mostly on calcareous or base-rich rocks near or in water F. crassipes

15a Terricolous plants 16

15b Plants growing on moist siliceous or calcareous rock or in streams ..................................... 17

16a Capsules symmetric, erect ..................................................................................................... F. viridulus

16b Capsules asymmetric, inclined

$F$. incurvus

17a Perichaetial leaves 4-6 times as long as wide, lanceolate, rather broad, suddenly narrowed to a short and wide, somewhat obtuse or \pm acute apex; plants hydrophilous, growing on siliceous rock often close to flowing water or inundated

F. pusillus

17b Perichaetial leaves to 6-7 (-9) times as long as wide, narrower, more gradually narrowed to slightly cuspidate point; plants growing on moist to wet calcareous rock ......... F. gracilifolius

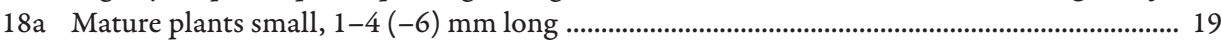

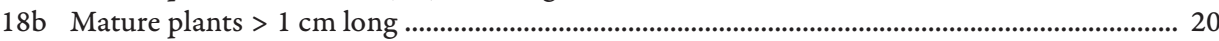

19a Leaves in 2-4 pairs, plants procumbent; margin at apex finely crenulate, margin on sheathing part of perichaetial leaves often coarsely dentate; dorsal lamina not extending to leaf base; terricolous, nearly always with capsules

F. exilis

$19 \mathrm{~b}$ Leaves in 4-5 (-10) pairs, increasing in length towards stem apex, plants erect; margin at apex entire or indistinctly crenulate by protruding cells, sheathing part of leaves entire; dorsal lamina reaching leaf base; plants growing on limestone or other base-rich rock and stones in or near water

F. arnoldii

20a Sheathing part of leaf $<1 / 3$ of total leaf length, leaves up to 10 times as long as wide; plants growing submerged in slowly flowing water F. fontanus

$20 \mathrm{~b}$ Sheathing part usually about $1 / 2$ of total leaf length, leaves much less than 10 times as long as wide.

21

21a Leaf margin dentate with large and smaller teeth alternating, particularly near apex; several rows of cells near margin forming pale band

.. 22

$21 \mathrm{~b}$ Leaf margin entire to crenulate, sometimes with 2-3 teeth near apex; leaf margin without pale band or just one marginal cell row paler 25

22a Laminal cells with one large conical mamilla each, marginal band conspicuous with strongly incrassate cells .................................................................................................................... F. serrulatus

22b Laminal cells smooth, not mamillate, at most sometimes slightly protuberant in dorsal part .... 23

23a Laminal cells (10-) 12-20 $\mu \mathrm{m}$ wide, lamina unistratose, \pm translucent; plants $2-10 \mathrm{~cm}$ tall ...

F. adianthoides

23b Laminal cells (5-) 6-12 $\mu \mathrm{m}$ wide; lamina irregularly bistratose, opaque; plants 1-3 cm long (F. dubius)

24

$24 \mathrm{a}$ Costa ending shortly below leaf apex in uppermost leaves F. dubius var. dubius

$24 \mathrm{~b}$ Costa shortly excurrent as mucro in uppermost leaves F. dubius var. mucronatus

25a Costa ending below leaf apex; upper laminal cells 10-14 (-18) $\mu \mathrm{m}$ long, not or only slightly bulging; perichaetia terminal

F. osmundoides

$25 \mathrm{~b}$ Costa excurrent as a short apiculus; upper laminal cells 6-10 $\mu \mathrm{m}$ long, distinctly bulging to mamillose; perichaetia at the base of shoots (F. taxifolius)

26a Plants to $2 \mathrm{~cm}$ long; leaves ovate-lanceolate, \pm parallel-sided and suddenly tapering at the apex

F. taxifolius var. taxifolius

26b Plants to $3(-6) \mathrm{cm}$ long; leaves mostly lanceolate to linear lanceolate, tapering from end of sheathing laminae to acuminate apex F. taxifolius var. pallidicaulis 


\section{Description of species}

Names of taxa that have been shown to occur in Hungary are printed in bold italics. The following taxa, which have either not (yet) been found in Hungary but might be expected, or which have been poorly recorded or even excluded, among them all Fissidens taxa known from countries adjacent to Hungary, are deliberately included to increase the usefulness of this account: Fissidens bryoides var. caespitans, F. fontanus, F. kosaninii, F. osmundoides, F. ovatifolius, F. rivularis, F. rufulus, F. serrulatus, F. taxifolius var. pallidicaulis.

Each section begins with a morphological description including comments, which highlight the differences from similar species. The section on morphology ends with specific references concerning the descriptions. Following the morphological details there are accounts of the taxa occurring in Hungary based on information from the revised specimens: habitat and substrate as noted in the convolutes, associated bryophytes as found in the packets, and distribution in Hungary as shown by a map. The number of specimens, the number of grid cells and the number of grid cells with recent finds are given. The altitudinal range based on all specimens of the species are also given. The enumeration of selected specimens is arranged according to the bryogeographical regions of Boros (1968) with slight modifications, and gives specimen data of at least one specimen for each region, where the species occurs. After the region the Niklfeld grid (NIKLFELD 1971) is given for each cited specimen. Since in some cases county boundaries and names have changed considerably, the county indicated in the specimen may not be the county to which the specimen's location belongs today. The next section is a compilation of the distribution in adjacent countries, including red list category if known, from the sources listed above (see methods). Under the heading "Literature" reports concerning the distribution in Hungary are discussed with respect to the results of the revision. The final section involves a discussion of the actual red list status and conservational aspects. In the case of controversial taxa, a note on taxonomic status is added.

\section{Fissidens adianthoides Hedw.}

(Figs 1, 2)

Plants robust, growing in lax turf, green, dark green to brown-green, not much branched; $2-10(-15) \mathrm{cm}$ long, decumbent to erect; rhizoids brown; leaf pairs numerous (20-35), of uniform size along stem, perichaetial leaves not differentiated from cauline leaves; leaves $c a$ 1.5-3 mm long and 0.5-1.0 mm wide, often slightly undulate when moist, lingulate-lanceolate, lanceolate-oblong or lingulate, at apex suddenly or \pm gradually narrowed to mostly acute, short tip, 
sometimes mucronate; apical lamina mostly shorter than sheathing part; dorsal lamina slightly decurrent at stem; margin coarsely and irregularly sharply serrate in upper part of leaf, below minutely serrulate or crenulate; elimbate, but margin differentiated by $2-4$ rows of more incrassate cells (not differing in size and shape from laminal cells), forming pale band; costa ending few cells below leaf apex, sometimes percurrent, rarely shortly excurrent, $55-65 \mu \mathrm{m}$ wide at mid leaf; lamina unistratose, rarely with bistratose spots near the costa, leaf cells turgid, not to slightly bulging, opaque, incrassate, in upper part isodiametric to irregularly hexagonal and rounded, $c a(10-) 12-18(-20) \mu \mathrm{m}$ long (measured in the direction of their greatest extension), near costa larger, to $30-40 \times 37-50 \mu \mathrm{m}$.

Dioicous or (rarely) autoicous; archegonia at the end of short axillary branches in the middle of annual shoots, seta therefore originating in the middle of shoots; antheridia $240-300 \mu \mathrm{m}$ long, in short bud-like axillary branches. Sporophytes not rare (in $43 \%$ of specimens seen).

Seta reddish to brownish, inserted laterally, to $3 \mathrm{~cm}$ long; capsule (erect to) inclined to horizontal, straight or (weakly) curved, elongate-ovate to ellipsoid, contracted below mouth when old, 1-1.5 (-2) mm long; lid nearly as long as the urn, longly and obliquely rostellate; peristome teeth $85-120 \mu \mathrm{m}$ wide at base, upper portion of filaments papillose, without spiral thickenings; spores (14-) $16-24(-27.5) \mu \mathrm{m}$, finely papillose to nearly smooth, ripening from late autumn to spring.

This robust species is characterised by (i) leaves lacking limbidium on all laminae, (ii) margin differentiated by a pale band of 2-4 rows of incrassate cells, crenulate below and coarsely serrate to dentate at apex, at least in uppermost leaves, and (iii) by large laminal cells, slightly bulging but not mamillose, mostly $>10 \mu \mathrm{m}$ wide.

Similar species:

F. dubius: leaves more suddenly narrowed to apex, tapering only in uppermost part, \pm parallel-sided below; lamina opaque, laminal cells bulging, 8-12 $\mu \mathrm{m}$, lamina partly bistratose; leaf apex incurved, falcate in dry leaves, stem to 3 $\mathrm{cm}$ long ( $F$. adianthoides: leaves more gradually tapering, widest below middle; lamina transparent, laminal cells not bulging, 10-18 $\mu \mathrm{m}$, lamina mostly completely unistratose; leaf apex curved downward and at the same time twisted and undulate in dry leaves; stem to $8 \mathrm{~cm}$ long).

F. osmundoides, F. serrulatus, F. taxifolius: see the notes under these species.

References: LIMPRICHT (1890: 449-451), DEMARET and CASTAGNE (1959: 52-53, 81-83), Bruggeman-NANnenga (1989: 88), Ahrens (2000: 102-103), Cortini Pedrotti (2001: 140-141), Smith (2004: 240-243, 257-258), Casas et al. (2006: 124), GUerRA and Ederra (2015: 182-183). 


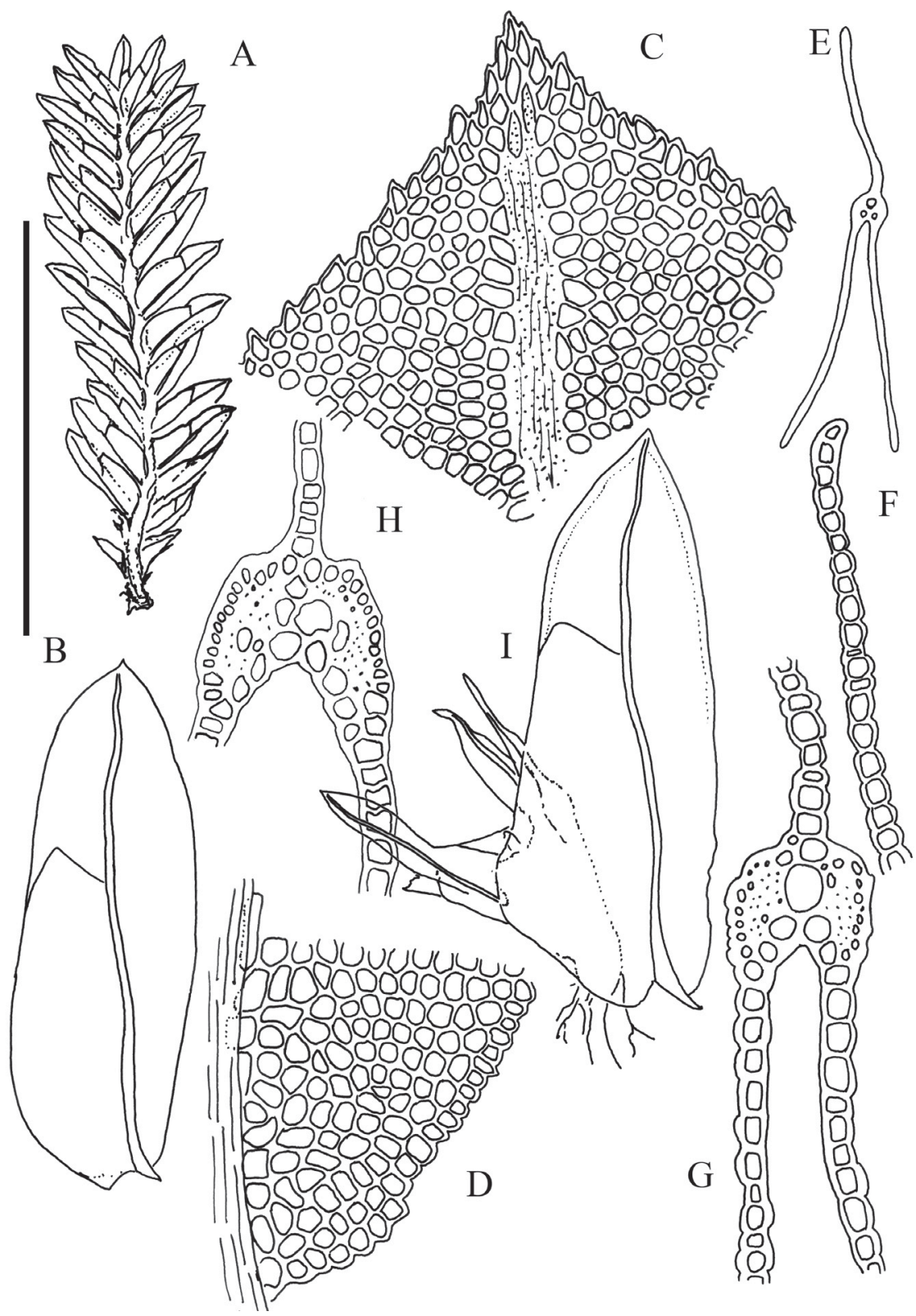

Fig. 1. Fissidens adianthoides: $\mathrm{A}=$ habit; $\mathrm{B}=$ leaf; $\mathrm{C}=$ leaf apex; $\mathrm{D}=$ base of dorsal lamina; $\mathrm{E}=$ transverse section of leaf; $F=$ transverse section of dorsal lamina in lower half of leaf; $G, H=$ transverse sections of costa ( $\mathrm{H}$ showing partially bistratose lamina near costa in vaginant lamina); $\mathrm{I}=$ leaf with perichaetium. Scale bar: A: $-4.6 \mathrm{~mm}$; B, I: $-2 \mathrm{~mm}$; C, D, F, G, H $-200 \mu \mathrm{m}$; E $-800 \mu \mathrm{m}$ [Erzberger 6246]. 
Habitat: In bogs or marshes, often near springs, streams, and lakes, on seeping rocks (in wet meadows, spring mire, alder carr, ash-alder carr, calcareous fens, Schoenetum nigricans, rarely in dried-out fish ponds, on wet sand in conifer plantations).

Substrate: On damp or wet soil, on peat (rarely on decaying wood, wet sand).

Associated bryophytes: Aneura pinguis, Aulacomnium palustre, Bryum pseudotriquetrum, Calliergonella cuspidata, Campylium protensum, C. stellatum, Chiloscyphus pallescens, Climacium dendroides, Conocephalum sp., Cratoneuron filicinum, Dicranodontium denudatum, Dicranum bonjeanii, Drepanocladus sendtneri, Eurhynchium striatum, Lophocolea bidentata, Palustriella commutata, Pellia endiviifolia, Philonotis caespitosa, Plagiochila porelloides, Plagiomnium elatum, $P$. undulatum, Plagiothecium nemorale, Sphagnum palustre, Sphagnum sp., Thuidium philibertii, Thuidium sp., Tomentypnum nitens.

Vertical distribution: $100-650 \mathrm{~m}$ a.s.l.

Distribution in Hungary: (108 specimens, 41 grid cells, of which 10 represent recent finds). - Zemplén Mts (7594.4) Comit. Abaúj-Torna. In pratis humidis cum Sphagnum vallis Komlóskapatakvölgy prope pag. Pálháza 29.05.1952, leg. L. Vajda BP 10433. Aggtelek Karst (7589.2) Comit. Borsod-Abaúj-Zemplén. In terra in Alnetum in valle Kopolya-völgy prope Szín, 200 m, 26.04.1994, leg. B. Papp BP 166156. Gödöllö Hills (8381.4) Comit. Pest. In pratis paludosis lacus ad Veresegyház, $150 \mathrm{~m}, 06.03 .1919$, leg. Á. Boros BP 102. Vértes Mts (8575.2) Comit. Komárom. In limosis prope pag. Oroszlány, 20.07.1954, leg. L. Vajda BP 27809; (8575.4) Comit. Fejér. Ad fontes in alnetis ad lacum rivi Éger-árok prope Pusztavám, 250 m, 26.09.1935, leg. Á. Boros BP 94414 and BP 94415. Gerecse Mts (8577.1) Comit. Komárom. In pratis humidis versus stationem Szár prope pag. Felsőgalla, 200 m, 25.03.1936, leg. Á. Boros BP 105 and BP 94416. Velence Mts (8777.3) Comit. Fejér. In locis humidis, ad fontes rivi Bella-patak supra Pákozd, sol. granit., 180 m, 15.03.1938, leg. Á. Boros BP 104. Bakony Mts (9070.3) Comit. Veszprém. Ad margines rivi Lesencepatak in alnetis prope Uzsa, 19.09.1953, leg. L. Vajda BP 26450; (8871.3) Veszprém County, wetland at Csigere stream, Ajkarendek. N 47 08' 23.9”, E 17³ 33' 21.8”, 09.05.2004, leg. B. Papp BP 171452. Balaton Uplands (9172.2) Comit. Veszprém. In loco paludoso Sásdirétek inter pag. Köveskál et Szentbékkála, 130 m, 04.08.1996, leg. B. Papp BP 163336. Keszthely Mts (9169.1) Comit. Veszprém. In uliginosis ad Nagyrét prope Zalaszántó, 01.04.1955, leg. L. Vajda BP 46452. Sopron Mts (8265.4) Sopron: Kistómalmi láp, 27.08.2000, leg. P. Erzberger (Erzberger 6488) and B. Papp BP 172942. Kőszeg Mts (8665.3) Comit. Vas. In limosis prope pag. Köszegszerdahely, 19.06.1970, leg. L. Vajda BP 75510; (8664.4) Locus natalis: Praenoricum, in pratis humidis (Caricetum davallianae) ad pag. Bozsok, 28.05.1954, leg. Á. Boros et M. Kovács, det. Á. Boros BP 94407. Örség (9165.1) Szőce, Réteg-forrás, 16.07.1997, leg. P. Erzberger (Erzberger 3535); (9065.4) Praenoricum: Őrség, Cariceto echi- 
natae-Sphagnetum in valle Alsó-vgy, sub pg. Szőce, 04.10.1954, leg. T. Pócs and Gelencsér BP 58831 and BP 94403. Vendvidék (9163.1) Vas County, Örség, aroung Grajka spring at Kétvölgy, 300 m, 22.07.2000, leg. B. Papp BP 174672. Vas (8967.1) Comit. Vas. In valle rivi Koponyáspatak prope pag. Kám, 05.09.1958, leg. L. Vajda BP 59521. Zala (9068.2) Zala County. In the meadow Türjei-láprét between Türje and Batyk in Molinietum, 29.07.2000, leg. B. Papp BP 167745. Inner Somogy (9669.3, 9669.4 or 9769.2) Comit. Somogy. In pratis paludosis ad Bükk-őrh. versus Kaszó pr. Somogyszob, 142 m, 17.04.1938, leg. Á. Boros BP 106. Fertő Hills (8366.2) Győr-Sopron-Moson County, Schoenetum nigricantis meadow around Fertő lake at Fertőszéplak, N 47 39' 7.4”, E 16 48' 32.7', 120 m, 02.10.2011, leg. B. Papp BP 184896. Kisalföld (8471.4) Comit. Győr. In pratis limosis ad pag. Felpéc, 22.06.1932, leg. S. Polgár BP 94383. Hanság (8270.3) Comit. Moson. In turfosis ad Ottómajor prope Lébény, territ. Hanyság dict., 23.3.1027, leg. S. Polgár BP 94382. Danube-Tisza Interfluve (8781.1) Comit. Pest. In pratis turfosis versus Madencia-puszta prope pag. Ócsa, $100 \mathrm{~m}$, 01.10.1940, leg. Á. Boros BP 101; Pest County, Ócsa, Turjános wetland, N 47 $17^{\prime}$ 25.0”, E 19 13'06.6”, 100 m, 27.08.2013, leg. B. Papp BP 187119. Danube inundation area (8680.2) Comit. Pest. Ad rivum flum. Danubii inter pag. Dunaharaszti et Soroksár, 16.04.1930, leg. J. Szepesfalvy BP 170356.

Distribution in adjacent countries: In all countries surrounding Hungary and not red-listed in any of them (HodGetTs 2015).

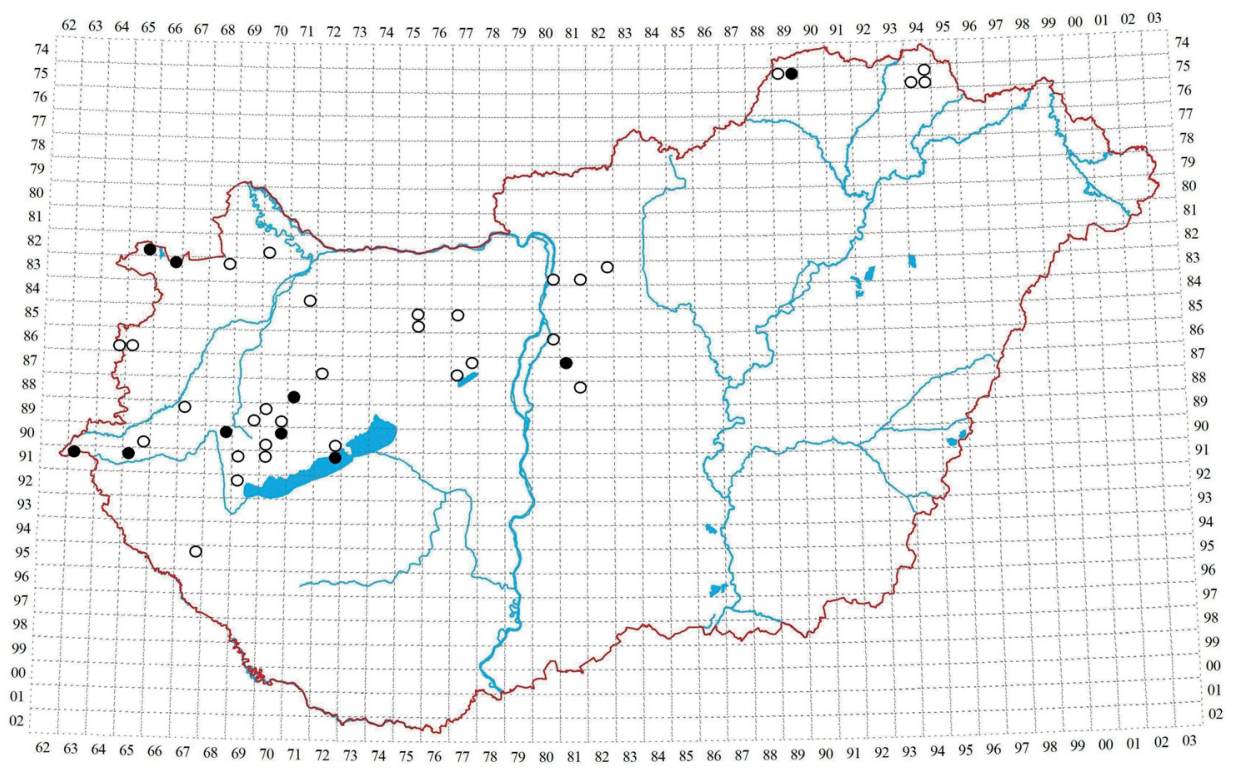

Fig. 2. Records of Fissidens adianthoides. 
Literature: Some of the regions listed in Boros (1968) are not supported by vouchers: Bükk Mts and Pilis Mts. An additional region not mentioned by Boros (1968) is Gerecse Mts.

Red list status and conservational aspects: NT (PAPP et al. 2010). In view of the fact that there are only 10 grid cells, where the species is known to grow at present, VU would seem appropriate, also in view of the documented loss of habitats. In this context, it is significant that nearly all recent records are in localities, where the species was known in the earlier 20th century, and that many wetlands where the species once grew are deteriorated or have been destroyed. Examples are the calcareous fens of Veresegyház or the springs on the Danube bank on the island of Csepel near Soroksár. The remaining wetlands where this species still exists should be protected and their conditions should be monitored.

Fissidens arnoldii R. Ruthe

(=F. obtusifolius auct. non Wilson)

(Figs 3, 4)

Plants solitary or growing in groups in mostly small and lax turf, bluish green, to $3.5 \mathrm{~mm}$ long, unbranched or little branched; rhizoids brown; leaves in 4-5 (-10) pairs, upper leaves crowded, much longer than lower cauline leaves; cauline leaves $0.6-0.8 \mathrm{~mm}$ long and $0.25-0.3 \mathrm{~mm}$ wide, $2-3$ times as long as wide, perichaetial leaves $1.2-1.4 \mathrm{~mm}$ long, leaves rather broad and short, ovate to oblong-lingulate, apex short, obtuse (in some leaves \pm acute) to rounded, apical lamina slightly shorter than sheathing part or (in perichaetial leaves) of equal length; dorsal lamina ceasing above insertion or reaching the stem; margin entire or indistinctly crenulate by protruding cells near apex; elimbate, but vaginant laminae of perichaetial leaves regularly with a border of narrow, elongate, incrassate cells, costa stout, ending 2-7 cells below leaf apex; lamina unistratose, laminal cells in upper part irregularly hexagonal to quadrate, thin-walled, mostly 6-12 $\mu \mathrm{m}$, in the middle of the dorsal lamina 7-12 (-18) $\mu \mathrm{m}$ long and 6-11 $\mu \mathrm{m}$ wide.

Dioicous, male plants as large as or smaller than female plants; archegonia ca $200 \mu \mathrm{m}$ long, terminal; antheridia 160-220 $\mu \mathrm{m}$ long, terminal. Sporophytes usually present and often abundant (in $36 \%$ of specimens seen).

Seta terminal reddish, ca 1.5-2.5 mm long; capsule erect, symmetric, ovate, 0.4-0.5 mm long; lid conical, weakly to shortly rostellate, $0.25-0.3 \mathrm{~mm}$ long; peristome teeth at their base 33-38 $\mu \mathrm{m}$ wide, filaments papillose, with spiral thickenings; spores $14-16 \mu \mathrm{m}$, finely papillose to nearly smooth, ripening from late summer to autumn.

This small hydrophilous species is characterised by (i) leaves lacking limbidium on all laminae except vaginant laminae of perichaetial leaves, (ii) margin 
smooth to finely crenulate, (iii) leaf apex obtuse to rounded, rarely acute, and (iv) habitat: growing on limestone and basic rocks in and near streams and rivers.

The typically obtuse leaf apex with slightly crenulate margin and a cell arrangement approaching concentric circles (similar to Anastrophyllum minutum) usually make $F$. arnoldii an easily recognisable species.

Similar species:

F. bambergeri: plants mesophytic, terricolous; limbidium often reduced but rarely completely lacking in ventral and dorsal laminae, often intralaminar in vaginant laminae; dorsal lamina not reaching stem; leaf tip acute (F. arnoldii: plants hydrophilous, saxicolous; limbidium in traces in sheathing part, completely lacking in apical and dorsal parts, not intralaminar; dorsal lamina usually reaching stem; leaf tip mostly rounded obtuse).

F. exiguus, F. exilis: see the notes under these species.

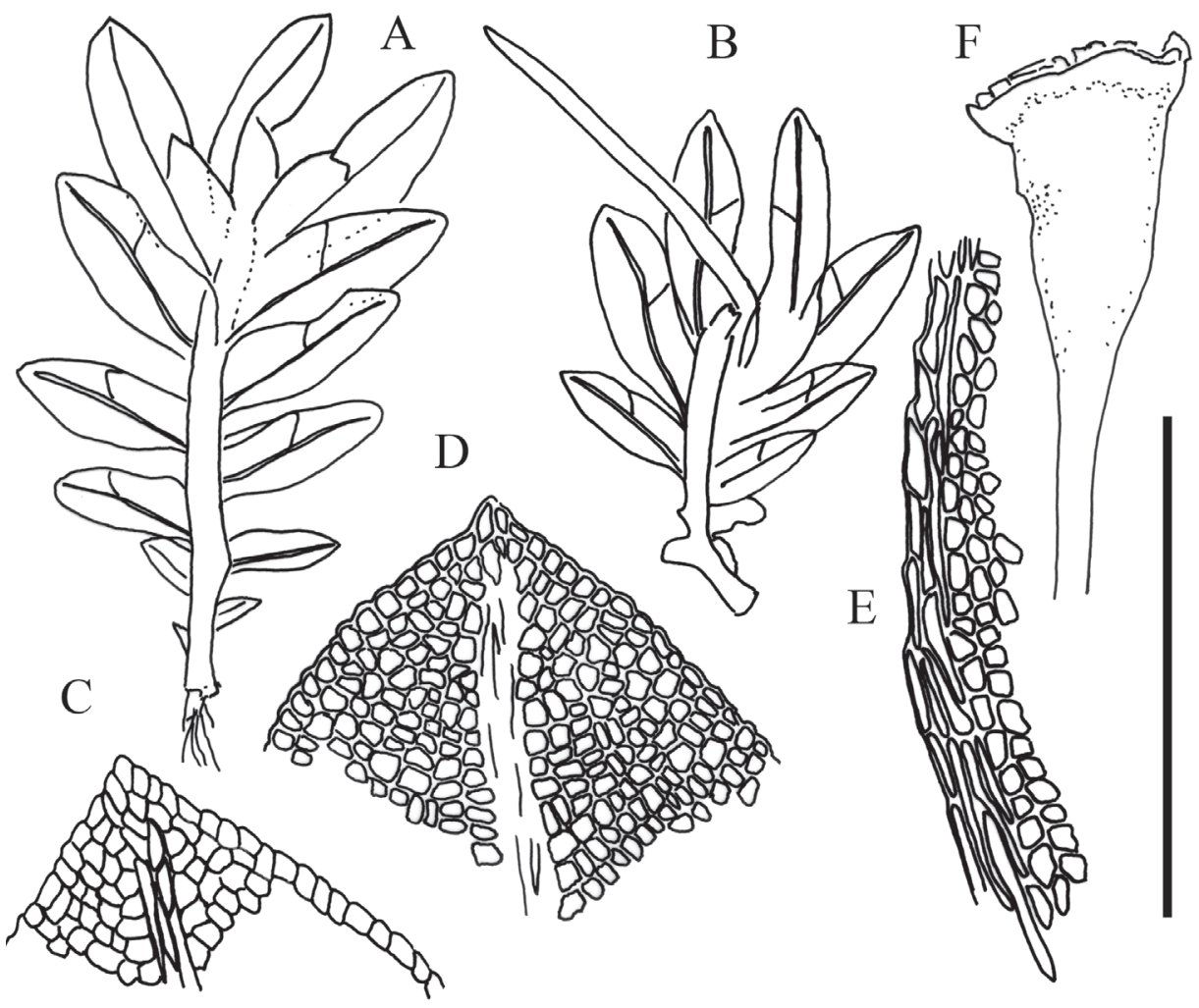

Fig. 3. Fissidens arnoldii: $\mathrm{A}, \mathrm{B}=$ habit ( $\mathrm{B}$ with juvenile sporophyte); $\mathrm{C}, \mathrm{D}=$ leaf apices; $\mathrm{E}=$ margin of vaginant lamina of perichaetial leaf; $F=$ dry deoperculate capsule. Scale bar: A, B - $2 \mathrm{~mm} ; \mathrm{C}, \mathrm{D}$, E - $200 \mu \mathrm{m} ; \mathrm{F}-800 \mu \mathrm{m}$ [A, D, F: BP 94253, B, C, E: Erzberger 7325]. 
References: Limpricht (1890: 425-426, 444-446), BRUgGEMAN-NANNENGA (1989: 84-85), AHRENs (2000: 103-105).

Habitat and substrate: On moist walls (limestone, concrete) near streams and rivers, subject to regular temporary inundation, mostly at watermills, often in the splash zone, rarely on andesite stones in small stream.

Associated bryophytes: Amblystegium tenax, Fissidens crassipes, F. gracilifolius, F. cf. pusillus, Leptodictyum riparium, Poblia melanodon.

Vertical distribution: 100-360 m a.s.l.

Distribution in Hungary: (34 specimens, 13 grid cells, of which 6 represent recent finds). - Aggtelek Karst (7589.4) Comit. Borsod-Abaúj-Torna, Mts Aggteleki karst, on a concrete wall along the stream Henc under the bridge at Úttörőtábor between Perkupa and Szőlősardó, 150 m, 05.08.1994, leg. B. Papp BP 164392 (originally as F. kosaninii, later revised as Fissidens exiguus by B. Papp 12.2001, see also PAPP and RAJCZY (1997), and later revised as F. pusillus by B. Papp, see PAPP (2009)). Cserhát Mts (8083.3) Cserhátszentiván, Cserkútipatak, Stein im Bachbett, mit Amblystegium tenax, 05.08.2001, leg. P. Erzberger B-Erzberger 7325, dupl. BP 168080, det. P. Erzberger, conf. M. Ahrens 2002 (ERzberger 2002). Börzsöny Mts (8180.1) Pest County, Szokolya, „Les-völgy, a vasúti hídnál patakmederben és a hídlábon", on concrete at the railway bridge across the stream in Les-Valley, N 47 52'31.5”, E 19 01' 48.2”, 175 m, 27.08.2015, leg. J. Nagy, det. P. Erzberger (hb. J. Nagy, dupl. B-Erzberger s.n.). Vértes Mts

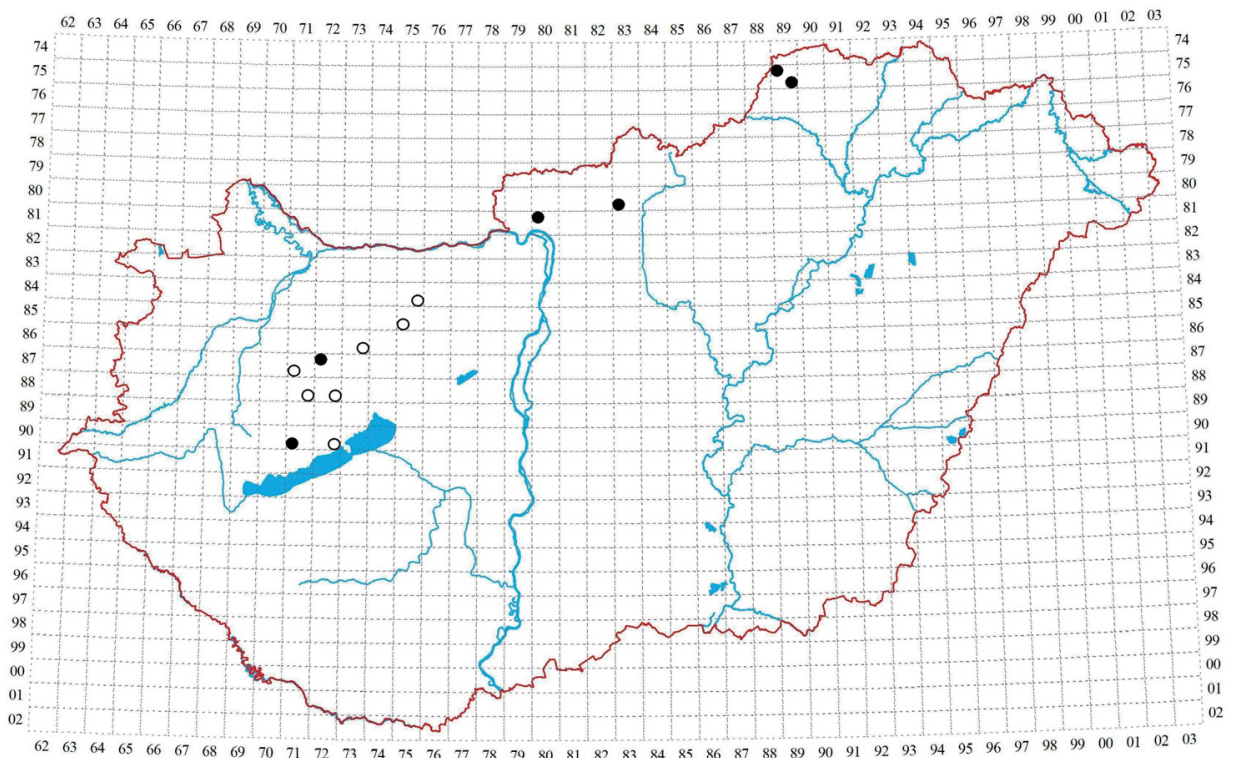

Fig. 4. Records of Fissidens arnoldii. 
(8475.4) Comit. Komárom: Mühle bei Környe, an nassen, mit Kalksinter bedeckten Mauern, 150 m, 10.1949, leg. L. Baksay et Á. Boros (Fissidens crassipes in mixture with $F$. arnoldii. Cryptogamae exsiccatae editae a Museo Hist. Natur. Vindobonensi 3743) BP 78136. Bakony Mts (8871.4) Comit. Veszprém. In muris irrigatis calc. molae Vashámori malom prope pag. Kislöd, 270 m, 05.06.1949, leg. Á. Boros BP 94249. Balaton uplands (9071.3) Veszprém County, stream at Széles forrás near Monostorapáti, limestone rocks N 46 56' 13.8”, E $17^{\circ} 34^{\prime} 52.3$ ”, $170 \mathrm{~m}, 25.08 .2012$, leg. B. Papp BP 186210. Danube inundation area (8779.3-4) Comit. Pest. In muris humidis Kőhíd ad Szigetújfalu, 100 m, 09.05.1954, leg. Á. Boros BP 94241.

Distribution in adjacent countries: Only in Croatia, Romania (EN), Ukraine and Slovakia (CR) among the countries adjacent to Hungary; listed in the Red data book of European bryophytes in the R (rare) category (ECCB 1995); candidate for the new Red data book of European bryophytes (HODGETTS 2015).

Literature: Boros (1951) contains an enumeration of all Hungarian occurrences found by himself, exclusively near watermills, and a discussion of the question of its native habitat. Boros also comments on F. obtusifolius Wilson, a species widely distributed in Eastern North America and not identical to $F$. arnoldii (Corley et al. 1981, Pursell 2007). PApP et al. (1999-2000) list all Hungarian occurrences known at that time and present a map in a case study for the estimation of population size and red list assessment according to IUCN (1978). Until then, the species was known only from the Transdanubian part of the country. ERZBERGER (2002) reports the occurrence in Cserhát Mts, and PAPP and ERZBERGER (2003) report another re-find of an old occurrence. Since then, essentially three more points have been added to the distribution map, two in Aggtelek Karst and one in Börzsöny Mts (see specimens above), extending the range towards the northern mountain range.

Red list status and conservational aspects: VU (PAPP et al. 2010); in view of only six grid cells, where the species is known to grow at present, this seems appropriate. Many of the old occurrences (e.g. at watermills that are no longer in use or have been destroyed) have vanished, but also some new ones have been detected recently. However, these are mostly very small populations. Considering the fact that this species is rare in a European context, Hungary has some responsibility for the protection of the extant populations. The maintenance of water quality in small streams seems to be the most important, since eutrophication leads to a decrease of the species due to the dominance of algae.

Interestingly, in other Central European countries, F. arnoldii occurs mainly at the artificial embankments of great rivers (MEINUNGER and SCHRÖDER 2007), but has not yet been found in this habitat in Hungary. 


\section{Fissidens bambergeri Schimp. ex Milde (三F. viridulus var. bambergeri (Schimp.) Waldh.)}

(Figs 5, 6)

Plants in small, lax turf or gregarious, green to yellowish green, only a few (2-3) millimetres long, decumbent, unbranched or little branched; leaves in 4-12 pairs, to $1.6 \mathrm{~mm}$ long and $0.25-0.4 \mathrm{~mm}$ wide, lingulate to lingulate lanceolate, abruptly narrowed to a short, mostly distinct point; apical lamina shorter than the vaginant laminae, dorsal lamina not extending to leaf base; margin \pm entire, limbidium mostly completely lacking in lower leaves, also in upper leaves often incomplete and often developed only in vaginant laminae, where it can branch and become intramarginal, unistratose, consisting of 1-2 rows of cells in upper part of leaf and of 4-5 rows of cells in sheathing part; costa stout, ending in or below the leaf apex; lamina unistratose, cells in upper part of leaf \pm hexagonal, 5-10 (-12) $\mu \mathrm{m}$ long (measured in the direction of their greatest extension).

Polyoicous, with terminal inflorescences often synoic, rarely additional archegonia naked below perichaetium, rarely male foliate branches on older part of stem; archegonia 180-240 $\mu \mathrm{m}$ long, antheridia 160-220 $\mu \mathrm{m}$ long. Sporophytes often present, but rarely abundant, often only a few (in $22 \%$ of specimens seen).

Seta terminal, yellowish to reddish, only few millimetres (to $c a 5 \mathrm{~mm}$ ) long, with a sharp bend at base; capsules erect and symmetric, ovate, ca $0.7 \mathrm{~mm}$ long, strongly contracted below mouth; lid conical, ca $0.5 \mathrm{~mm}$ long, obliquely rostellate; peristome teeth to $32 \mu \mathrm{m}$ wide at base, filaments weakly papillose, with dense spiral thickenings; spores ca 12-14 $\mu \mathrm{m}$, finely papillose to almost smooth.

This small terricolous species is characterised by (i) an incomplete limbidium lacking to a variable degree on apical and dorsal laminae, often intramarginal in vaginant laminae, (ii) the dorsal lamina not extending to the stem, (iii) the apical lamina shorter than the vaginant laminae, (iv) small upper laminal cells, and (v) the polyoicous sexual condition with an often synoicous terminal inflorescence.

Similar species:

F. viridulus: limbidium complete or at least present on all three laminae, not branched and intralaminar in sheathing part; dorsal lamina reaching stem; upper laminal cells 12-16 $\mu \mathrm{m}$ long ( $F$. bambergeri: limbidium incomplete and often lacking on apical and dorsal laminae, often branched and intralaminar in sheathing part; dorsal lamina not reaching stem; upper laminal cells smaller, 5-10 (-12) $\mu \mathrm{m}$ long).

F. crispus: see note under that species.

The only other small species with limbidium \pm confined to the vaginant laminae of the perichaetial leaves are rock dwellers growing near or in water: $F$. arnoldii and F. exiguus; see notes under these species. 
References: Limpricht (1890: 425, 434-435), Demaret and CASTAGNE (1959: 52, 54-55), Ahrens (2000: 99-101, 105-106), Cortini Pedrotti (2001: 133-135).

Habitat and substrate: Mostly on neutral to basic, rarely slightly acidic soil in open to slightly shaded situations (dolomite and andesite grassland, abandoned quarry, in a cave entrance on dolomite, along forest paths, in hollow road).

Associated bryophytes: Barbula unguiculata, Bryum ruderale, Eurhynchium hians, Fissidens dubius, Hypnum cupressiforme, Phascum cuspidatum var. papillosum, Pottia lanceolata, Rhynchostegiella tenella.

Vertical distribution: 300-465 $\mathrm{m}$ a.s.l.

Distribution in Hungary: (9 specimens, 9 grid cells, of which 6 represent recent finds). - Bükk Mts (8088.1) Comit. Heves. In dumetosis ad vallem Újhatár-völgy prope Szarvaskő, 300 m, 22.04.1951, leg. Á. Boros BP 94238 sub Fissidens intralimbatus Ruthe. Börzsöny Mts (8180.1) Pest County, Szokolya, Nagy-Kö-hegy, Quercetum pubescentis, andezit sziklagyep, cserjés N $47^{\circ} 52^{\prime}$ 32.8”, E $19^{\circ} 02^{\prime} 11.5^{\prime \prime}, 340$ m, 29.10.2015, leg. J. Nagy det. P. Erzberger (hb. J. Nagy, dupl. B-Erzberger s.n.). Buda Mts (8479.4) Budapest, Nagy Hárshegy, Abbruchkante über Steinbruch, 07.02.2001, leg. et det. P. Erzberger, conf. Th.

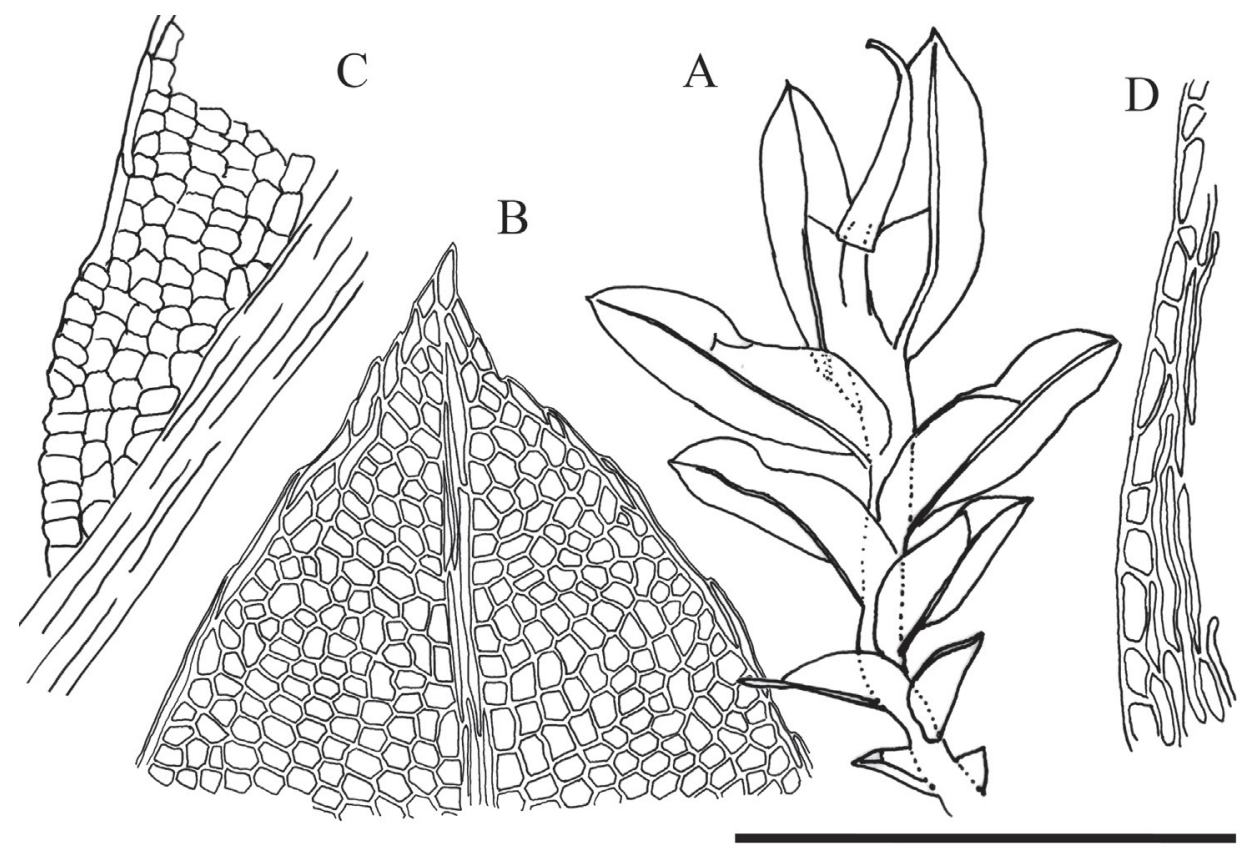

Fig. 5. Fissidens bambergeri: $\mathrm{A}=$ habit (plant with young sporophyte); $\mathrm{B}=$ leaf apex; $\mathrm{C}=$ base of dorsal lamina; $\mathrm{D}=$ intramarginal limbidium at base of vaginant lamina. Scale bar: $\mathrm{A}-2 \mathrm{~mm} ; \mathrm{B}, \mathrm{C}$, $\mathrm{D}-200 \mu \mathrm{m}$ [Erzberger 21092]. 
Homm (B-Erzberger 6687). Gerecse Mts (8377.1) Comit. Komárom. In cava rupe calcar. montis Kajmát prope Héreg, 300 m, 21.04.1939, leg. Á. Boros BP 94110 sub Fissidens bryoides. Vértes Mts (8675.2) Csákberény, Ugró-völgy, Erde zwischen Dolomitfelsen, 29.04.2001, leg. et det. P. Erzberger, conf. Th. Homm (B-Erzberger 7084). Kőszeg Mts (8664.4) Kom. Vas, Bozsok, Aufstieg zum Kalapos-kő, Erdanriss, Wegrand, 06.11.2015, leg. P. Erzberger and K. Baráth (B-Erzberger 21106). Zala (9166.4) Zalaegerszeg, mélyút az Alsóerdő melletti téglagyárhoz [with a note in Boros's hand: limbusa gyenge. rövid levelü. esetleg a var. viridula? (border weak, leaves short. perhaps var. viridula?)] 11.05.1940, leg. A. Visnya, det. Á. Boros as Fissidens bryoides BP 94774. Vendvidék (9162.2) Vas County, Felsőszölnök, Szölnöki-patak valley, on soil near the path, N $46^{\circ} 52^{\prime}$ 16.6”, E 1607’30.4”, 300 m, 16.07.2014, leg. P. Erzberger (B-Erzberger 18444).

Distribution in adjacent countries: Information incomplete, missing in checklists, partly due to inclusion in the synonymy of F. viridulus; in Austria included in F. viridulus (KöcKINGER et al. 2011); listed for Slovenia (MARTINČIČ 2003 as F. limbatus var. bambergeri), but omitted in MARTINČIČ (2016).

Literature: To my knowledge this taxon has not been mentioned in the Hungarian literature. However, one collection (BP 94238) of F. bambergeri had been named $F$. intralimbatus by the collector Boros (see above, Bükk Mts). F. intralimbatus $\mathrm{R}$. Ruthe (=F. viridulus var. intralimbatus ( $\mathrm{R}$. Ruthe) Düll) is included in the synonymy of $F$. viridulus by most authors; according to CorTini PEDrotTi

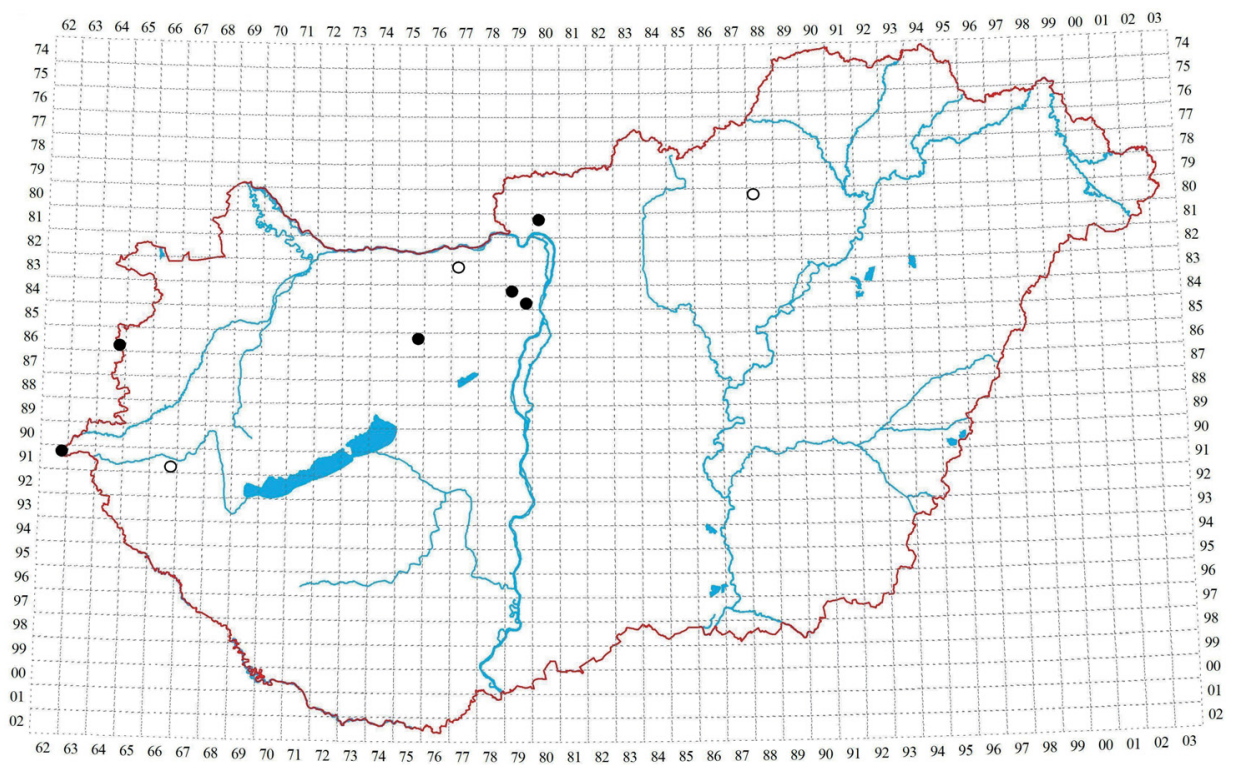

Fig. 6. Records of Fissidens bambergeri. 
(2001: 132) it is characterised by the limbidium confined to the sheathing part, smaller laminal cells $(7-11 \mu \mathrm{m})$ and smaller spores $(7-11 \mu \mathrm{m})$ than in F. viridulus. Not considering cell and spore dimensions, since these are very variable in Fissidens, the incomplete limbidium might suggest affinity to $F$. bambergeri. Apart from the above-mentioned collection, the name $F$. intralimbatus has been applied by Boros and Vajda to a few poorly limbate specimens of F. viridulus, $F$. pusillus, and F. gracilifolius in BP.

Red list status: At present, VU seems appropriate (only six recent finds). The distribution map is clearly very incomplete, since the species has not been recognised up to now.

Note on taxonomic status: Although F. bambergeri is accepted by several European authors (e.g. Ahrens 2000, Cortini Pedrotti 2001, Meinunger and SCHRÖDER 2007), others (e.g. SMITH 2004: 245) include it in synonymy of $F$. viridulus, some with reservations (KöCKINGER et al. 2008). Bruggeman-Nannenga studied an isotype of $F$. bambergeri and found that it represents a poorly limbate form of F. viridulus (Bruggeman-Nannenga in Hill et al. 2006, Ann. 108). According to my observations, F. bambergeri is sufficiently distinct in Hungary and should at present not be merged with $F$. viridulus, pending further studies.

Fissidens bryoides Hedw. var. bryoides

(=F. alpestris (Lindb.) J. J. Amann, F. decumbens R. Ruthe, F. inconstans Schimp.)

(Figs 7,8)

Plants in lax to \pm dense turf or in groups, mostly light green; to $1(-3) \mathrm{cm}$ long, sterile shoots sometimes taller; procumbent to \pm erect, mostly unbranched; rhizoids brown; leaves in 5-15 (-20) pairs, uniform in shape, (1.1-) 1.4-1.9(-2.5) $\mathrm{mm}$ long and (0.3-) 0.4-0.6 mm wide, 2-4 times as long as wide, perichaetial leaves (1.3-) 1.7-2.9 mm long; leaves lingulate-lanceolate, suddenly narrowed into a short, sharp and stout point; apical lamina about as long as the sheathing part or shorter, dorsal lamina (nearly) reaching the stem and not to slightly decurrent; margin often weakly and indistinctly denticulate near apex, otherwise entire; limbidium usually on all three laminas, but sometimes reduced towards base of dorsal lamina; narrow but very distinct, usually $2(-3)$-stratose, consisting of (1-) 2-3 (-4) rows of cells, in the middle of dorsal lamina 7-14 (-18) $\mu \mathrm{m}$ wide, at sheathing part $12-25(-30) \mu \mathrm{m}$ wide, mostly extending to apex and confluent with costa, but sometimes not (some narrowly rhombic cells just below apex), \pm colourless or yellowish; costa percurrent to shortly excurrent as mucro or ending just below apex, (40-) 50-60 (-70) $\mu \mathrm{m}$ wide at mid-leaf; lamina unistratose, cells in upper part of leaf \pm hexagonal or rounded hexagonal, ca 6-14 $\mu \mathrm{m}$, in the middle of the dorsal lamina (6-) 7-14 (-17) $\mu \mathrm{m}$ long and 7.5-11 (-14) $\mu \mathrm{m}$ wide. 


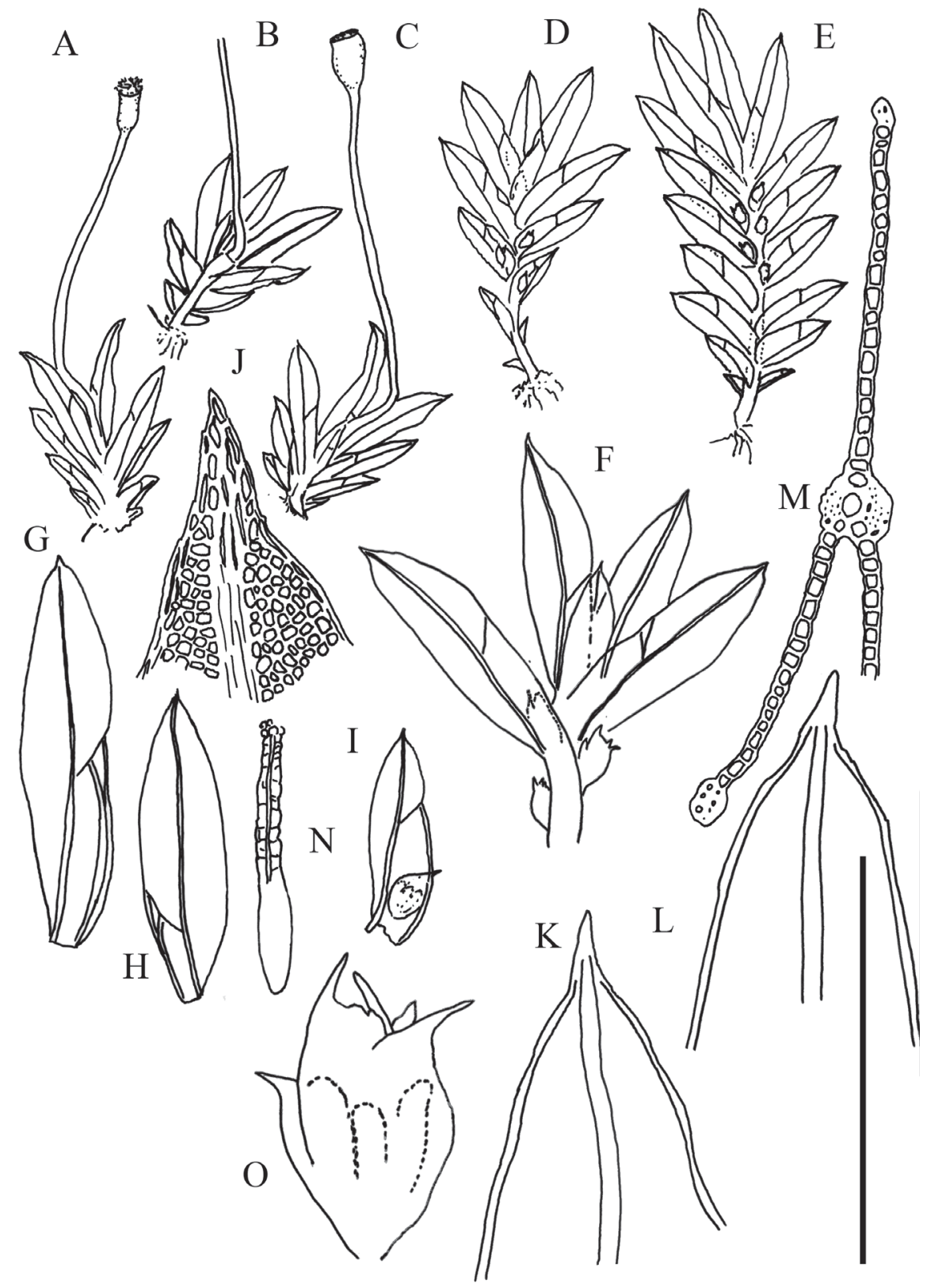

Fig. 7. Fissidens bryoides: A, B, C = habit of plants with sporophytes; D, E = habit of gametophytes with perigonial buds; F = detail of gametophyte with perigonial buds, lower leaves removed; $G, H, I=$ leaves (I with perigonial bud); J, K, L = leaf apices showing costa confluent with limbidium; $\mathrm{M}=$ transverse section of leaf; $\mathrm{N}=$ archegonium; $\mathrm{O}=$ perigonial bud with 3 antheridia. Scale bar: $\mathrm{A}-\mathrm{E}-4.6 \mathrm{~mm} ; \mathrm{F}-\mathrm{I}$ $-2 \mathrm{~mm} ; \mathrm{J}, \mathrm{M}-200 \mu \mathrm{m} ; \mathrm{K}, \mathrm{L}, \mathrm{N}, \mathrm{O}-400 \mu \mathrm{m}$ [A-E, G-N: Erzberger 5583; F, O: BP 94091]. 
Rarely with underground rhizoid tubers, roughly spherical, dark brown, multicellular, 75-100 $\mu \mathrm{m}$ in diameter.

Usually autoicous, rarely paroicous (e.g. BP 94144, see below), very rarely synoicous; archegonia 180-360 $\mu \mathrm{m}$ long, terminal; antheridia 100-170 (-200) $\mu \mathrm{m}$ long, mostly 3-6 in minute bud-like axillary branches with 3-5 perigonial leaves, but rarely also naked solitary in the axils of upper leaves, very rarely terminal and then mixed with archegonia. Sporophytes usually present, often abundant (in $82 \%$ of specimens seen).

Seta terminal, reddish or yellowish, (2-) 3-7 (-12) mm long; capsule erect, symmetric, very rarely slightly inclined, ellipsoid, contracted below mouth, urn 0.75-1.2 mm long; lid about half the length of the urn, conical, obliquely rostellate; peristome teeth at their base $37-53 \mu \mathrm{m}$ wide, filaments coarsely papillose, with spiral thickenings; spores (9-) 10-14 (-20) $\mu \mathrm{m}$, finely papillose to almost smooth, ripening in winter to spring.

This species is characterised by (i) usually numerous axillary bud-like perigonia along the stem, and (ii) the apical limbidium mostly extending to the mucronate leaf tip and usually confluent with the percurrent or excurrent costa.

Note on variability: Although the stem is usually unbranched, sometimes branched plants are also found. In these plants sporophytes may develop seemingly lateral, but this is due to branching of the stem (F. inconstans Schimp. see Fig. 22B for a similar branching in F. gymnandrus). Although antheridia are usually found in axillary perigonia, sometimes also naked axillary or terminal antheridia are found, in the last case together with archegonia in a synoicous inflorescence. These aberrant plants usually occur together with numerous normal plants (BRUGGEMAN-NANNENGA 1989: 81). In an interesting specimen (BP 94144, Ómassa 1952, leg. Boros) the plants are regularly paroicous with naked antheridia below the perichaetium, a sexual condition that is also (rarely) found in $F$. viridulus. Rarely plants with slightly inclined capsules can occur.

Similar species:

F. bryoides var. caespitans: stems usually with a dense tomentum of deep red or occasionally brownish rhizoids; capsules usually inclined; spores larger, 16-20 $\mu \mathrm{m}$; hygrophilous plant (F. bryoides var. bryoides: rhizoids few, brownish; capsules usually erect; spores smaller, 10-14 $\mu \mathrm{m}$; non-hydrophilous plant).

$F$. gymnandrus, $F$. incurvus, $F$. rivularis, $F$. viridulus: see notes under these species.

References: Limpricht (1890: 428-429), DemARET and CASTAGNE (1959: 52-53, 60-62), Nyholm (1987: 8, 10-11), Bruggeman-Nannenga (1989: 80-81), Ahrens (2000: 99-101, 106-107), Cortini Pedrotti (2001: 127-128), SMith (2004: 240-242, 247-249), GUERRA and EdERRA (2015: 165-167). 
Habitat and substrate: On moist, bare, shaded clayey soil or soil-covered rocks mostly in woods, beside streams or lakes, on basic or acidic substrates (in many types of broad-leaved or coniferous forest, over different kinds of bedrock (sandstone, volcanic, calcareous), rarely on dead wood).

Associated bryophytes: Amblystegium serpens, Atrichum angustatum, A. undulatum, Barbilophozia barbata, Bartramia ithyphylla, Brachythecium velutinum var. velutinum, $B$. velutinum var. salicinum, Bryum argenteum, B. moravicum, B. subapiculatum, Campylium calcareum, C. chrysophyllum, Cephalozia bicuspidata, Cephaloziella divaricata, Ceratodon purpureus, Chiloscyphus pallescens, Dicranella heteromalla, Dicranum scoparium, Didymodon insulanus, Diphyscium foliosum, Ditrichum cylindricum, Ephemerum minutissimum, Eurhynchium hians, E. schleicheri, Fissidens dubius, F. exilis, F. taxifolius, Fossombronia pusilla, Homalia trichomanoides, Hypnum cupressiforme, $H$. lindbergii, Jungermannia byalina, Lophocolea bidentata, L. heterophylla, L. minor, Lophozia bicrenata, Mnium stellare, Plagiobryum zierii, Plagiochila porelloides, Plagiomnium affine, P. cuspidatum, Plagiothecium succulentum, Pleuridium subulatum, Pleuridium sp., Pohlia andalusica, P. cruda, P. nutans, P. wablenbergii, Polytrichum formosum, Pottia truncata, Ptilidium pulcherrimum, Reboulia hemisphaerica, Rhizomnium punctatum, Scapania mucronata, Scleropodium purum, Seligeria recurvata, Thamnobryum alopecurum, Thuidium recognitum, Tortula schimperi, T. subulata, Weissia longifolia.

Vertical distribution: $26-850 \mathrm{~m}$ a.s.l.

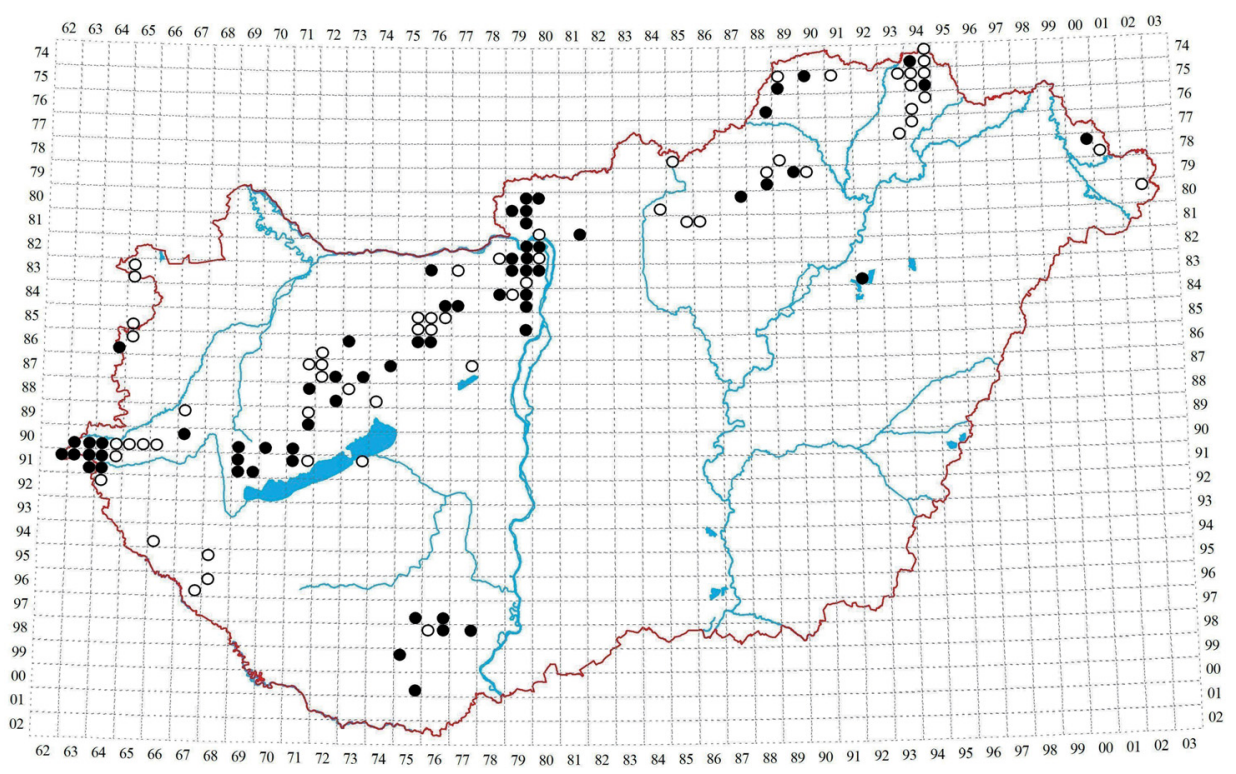

Fig. 8. Records of Fissidens bryoides. 
Distribution in Hungary: (more than 250 specimens, 121 grid cells, of which 63 represent recent finds) documented for all regions except Cserehát Hills, Putnok Hills, Gödöllő Hills, Naszály, Fertő Hills, Hetés, Göcsej, Inner Somogy, Kisalföld, Hanság, Nyírség, Dráva-sík and Danube inundation area. However, probably the species can be found also in these areas. This species is widely distributed in forests and prefers more acidic to subneutral soil conditions contrasting the other soil-dwelling species ( $F$. bambergeri, F. incurvus, F. viridulus).

Listing of regions and quotation of specimen data seem unnecessary.

Distribution in adjacent countries: Occurring in all neighbouring countries and red-listed in none of them (HodGetTs 2015).

Literature: Boros (1968), ORBÁN and VAJDA (1983) give general information, but emphasise that the species is less frequent in the lowlands.

Red list status: Least concern (LC).

Fissidens bryoides var. caespitans Schimp. (=F. curnovii Mitt., F. bryoides var. curnovii (Mitt.) J. J. Amann)

Plants growing in dark green patches or scattered, (4-) 6-20 (-40) mm long; stems matted below with tomentum of deep red or occasionally brown rhizoids; fertile plants smaller than sterile plants, with only 3-4 pairs of leaves; leaves in (3-4)-numerous (up to 25) pairs, $1.5-3 \mathrm{~mm}$ long and $0.3-0.7 \mathrm{~mm}$ wide, 3-5 times as long as wide; perichaetial leaves (1.9-) 2.2-3.1 mm long; leaves oblong to lanceolate, cuspidate; apical lamina shorter, as long as or longer than sheathing part; margin sinuously denticulate at apex; limbidium 2-3-stratose, colourless, confluent with percurrent to excurrent costa (usually indistinctly, or border ending just below apex), reaching stem and not to very slightly decurrent at base of dorsal lamina; limbidium 12-19.5 $\mu \mathrm{m}$ wide at middle of dorsal lamina; costa percurrent to excurrent; laminal cells (4.5-) 8-12 (-14) $\mu \mathrm{m}$ long and 4.5-9 $\mu \mathrm{m}$ wide in middle of dorsal lamina.

Autoicous, archegonia 280-400 $\mu \mathrm{m}$ long, terminal; antheridia (100-) 150-220 $(-250) \mu \mathrm{m}$ long, in dwarf axillary buds. Sporophytes common.

Seta red, 3.5-8 (-10) mm long, geniculate at base; capsules usually inclined but occasionally erect, (0.5-) $0.7-1.3 \mathrm{~mm}$ long, ellipsoid; lid $0.3-0.55 \mathrm{~mm}$ long; peristome teeth at base (34.5-) 39-54 (-58.5) $\mu \mathrm{m}$ wide; spores (12-) 16-20 $\mu \mathrm{m}$, nearly smooth.

This plant is characterised by (i) often (but not always) deep red to purplish rhizoids, (ii) inclined capsules, and (iii) its habitat in the inundation zone of streams, in the splash zone of waterfalls, etc.

Variability: HolyoAK and Whitehouse (1998) demonstrated that the colour of rhizoids of F. curnovii may change from brown to red upon cultivation, and many populations have brown rhizoids. 
Similar species:

F. bryoides: see note under that species.

References: Limpricht (1890: 431), Demaret and Castagne (1959: 62-64), Bruggeman-Nannenga (1985), Cortini Pedrotti (2001: 127-128), Sмiтн (2004: 240-242, 248-250).

Habitat, substrate: On moist acidic soil, flushed rocks and in moist rock crevices by streams and rivers at \pm normal water level.

Distribution in Hungary: Excluded. There are two collections in BP that might suggest some similarity with F. bryoides var. caespitans:

Zemplén Mts (7594.1) Comit. Abaúj-Torna. Ad margines sylvarum in monte Nagy Farkashegy, prope pag. Telkibánya, mtes Sátorhegység [note: Nagyon erős többsejtsoros szegély a leveleken, a száron lefut. Antheridiumok az alsó levelek tövében több leveles rügyek. Helytelen a kulcsokban a megállapítás, hogy a F. bryoidesnek egysejtsoros szegélye van. Mindig többsoros de keskeny szegélyű. (Very strong border consisting of several cell rows on leaves, decurrent along stem. Antheridia at the base of lower leaves in buds of several leaves. The statement in keys that $F$. bryoides has a border consisting of one cell row only is erroneous. The border consists always of several cell rows, but is narrow.)] 19.06.1960, leg. et det. L. Vajda as Fissidens curnovii Mitt. [in pencil: Curnovii felé? (towards Curnovii?)] BP 63066.

Upon re-examination of this specimen, it was revised to $F$. bryoides var. bryoides and annotated as follows: male buds present, rhizoids brown; spores 16-20 $\mu \mathrm{m}$; rhizoids also on upper parts of stem, but not forming tomentum; peristome teeth $35-50 \mu \mathrm{m}$ wide at base: these characters suggest $F$. curnovii; however, the most important characters: tomentum of red rhizoids, inclined capsules, hygrophilous habitat are not observed. The limbidium is only $10 \mu \mathrm{m}$ wide at the middle of the dorsal lamina. F. bryoides, perhaps transition to var. caespitans. P. E. 2016.

Another collection that shows some characters suggestive of $F$. bryoides var. caespitans is the following: Vendvidék (9063.4) Comit. Vas. In silvis vallis Zsidapatak prope Zsida, 250 m, 02.04.1933, leg. Á. Boros BP 94795, dupl. BP 139. Annotation: Fissidens bryoides var. bryoides fo. An unusual form, in leaf shape and size, and extent of well-developed limbidium. The limbidium is pluristratose, ca $15 \mu \mathrm{m}$ wide in dorsal lamina (F. rivularis: $20-25(-30) \mu \mathrm{m})$ and ca $35 \mu \mathrm{m}$ wide in vaginant laminae (F. rivularis: $45-50(-60) \mu \mathrm{m}$; GUERRA and EDERRA 2015). The costa is percurrent, not excurrent (F. rivularis: excurrent in mucro up to 150 $\mu \mathrm{m}$ long), confluent with limbidium. This excludes $F$. rivularis and $F$. bryoides (including var. caespitans; however, the latter should have red rhizoids, inclined capsules and larger spores (SMITH 2004); since this collection is without sporophytes, var. caespitans cannot be considered). Although the specimen label does 
not give information on particular habitat, the plants seem to have grown near water, they are incrusted with silt or calcareous matter, and some leaves appear to have been eroded, so only the costa and limbidium remain, which might suggest flowing water. Plants growing in this type of habitat subjected to temporary inundation often show morphologically deviant features. This might explain the peculiar habit. The perigonial axillary buds and the limbidium confluent with the costa preclude other aquatic Fissidens. P. E. 07.02.2016.

Distribution in adjacent countries: Not reported from any of the neighbouring countries. There is an old report from Czechoslovakia (DEMARET and CASTAGNE 1959), but KUČERA et al. (2012) exclude the taxon. The occurrence of this oceanic-southern temperate species (Blockeel in BLOCKEEL et al. 2014: 7) in Central Europe seems highly improbable.

Literature: Not mentioned in Boros $(1953,1968)$ and OrBÁN and VAJDA (1983). Erzberger and PAPP (2004) quote details of the specimen BP 63066 (see above).

Note on taxonomic status: Bruggeman-Nannenga in Hill et al. (2006) reduces F. curnovii to varietal rank, "because, though extreme forms are clearly distinct from $F$. bryoides var. bryoides by red rhizoids, a thicker limbidium, inclined capsules and a cushion-like growth form, many collections cannot be identified with certainty" (Ann. 95). According to LIMPRICHT (1890: 431) "perhaps only a luxuriant form of F. bryoides".

Fissidens crassipes Wilson ex Bruch et Schimp.

(=F. crassipes subsp. crassipes, F. crassipes var. rufipes Schimp., F. mildeanus Schimp.)

(Figs 9, 10)

Plants mostly gregarious or growing in lax turf, often dirty green or brownish green, blackish below, \pm decumbent, $0.5-2(-4) \mathrm{cm}$ long, unbranched or little branched; rhizoids brown; leaves flaccid, in numerous (6-45) pairs, 1.1-3.0 $(-3.2) \mathrm{mm}$ long and $0.3-0.8 \mathrm{~mm}$ wide, well-developed leaves from sterile stems 3-6 (-8) times as long as wide, perichaetial leaves $2.0-3.6 \mathrm{~mm}$ long, \pm similar to cauline leaves; leaves lanceolate, oblong-lanceolate or elliptical-lanceolate to ovate lanceolate, in upper part \pm gradually or suddenly narrowed to a longer or shorter, mostly acute apex, apical lamina mostly longer than vaginant laminae or of equal length, but not rarely also shorter; dorsal lamina not reaching leaf insertion or only as a narrow band; leaf margin indistinctly denticulate at apex, otherwise entire, limbidium of narrow, elongate cells well developed, often yellowish or brownish to reddish, somewhat bulging, vanishing below leaf apex, consisting of 2-6 cell rows and at least locally pluristratose, in the middle of dorsal lamina (0-) 7-25 (-30) $\mu \mathrm{m}$ wide, 37-60 (-70) $\mu \mathrm{m}$ wide at sheathing part, ending at or 
above leaf base in dorsal lamina, often intralaminar at base of sheathing part; costa stout, (40-) 50-60 $\mu \mathrm{m}$ wide at mid leaf, ending few cells below leaf apex, sometimes percurrent, in older leaves often reddish brown; lamina unistratose, cells in upper part of leaf thin-walled to incrassate, irregularly hexagonal, ca (10-) $12-18(-25) \mu \mathrm{m}$ long (measured in the direction of their greatest extension), in the middle of dorsal lamina 9-23 (-30) $\mu \mathrm{m}$ long and 6-12 $\mu$ m wide, (6-) 10-14 $(-18) \mu \mathrm{m}$ wide in middle of apical lamina.

Autoicous, dioicous or synoicous; archegonia 420-660 $\mu \mathrm{m}$ long, terminal; antheridia (190-) 260-400 (-450) $\mu \mathrm{m}$ long, terminal. Sporophytes not rare, often abundant (in $29 \%$ of specimens seen).

Seta terminal, yellowish to reddish, becoming brown with age, 3-8 (-10) $\mathrm{mm}$ long, geniculate at base; capsules erect to weakly inclined, \pm symmetric, el-

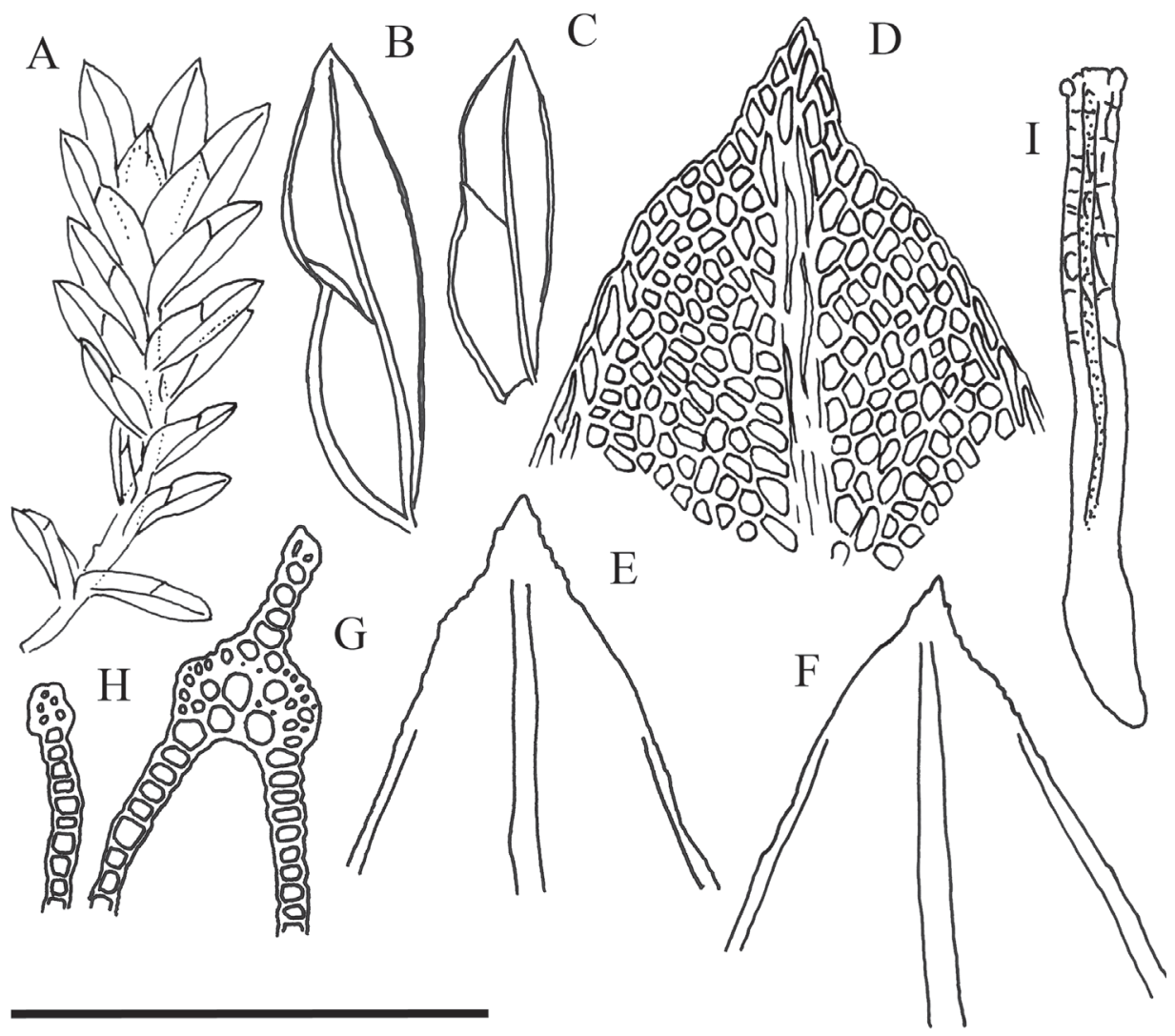

Fig. 9. Fissidens crassipes: $\mathrm{A}=$ habit; $\mathrm{B}, \mathrm{C}=$ leaves; $\mathrm{D}, \mathrm{E}, \mathrm{F}=$ leaf apices; $\mathrm{G}=$ transverse section of costa and dorsal lamina; $\mathrm{H}=$ transverse section of limbidium; $\mathrm{I}=$ archegonium. Scale bar: $\mathrm{A}-4.6$ mm; B, C - 2 mm; D, G, H - $200 \mu \mathrm{m}$; E, F, I - $800 \mu \mathrm{m}$ [Erzberger 16549]. 
lipsoid to oblong-ovate, $0.6-1.5 \mathrm{~mm}$ long; lid conical, $0.4-0.6 \mathrm{~mm}$ long, shortly and obliquely rostellate; peristome teeth at their base $51-86 \mu \mathrm{m}$ wide, filaments strongly papillose, with spiral thickenings; spores (14-) 15-27 (-30) $\mu \mathrm{m}$, finely papillose to nearly smooth, ripening from late autumn to spring.

This species is characterised by (i) mostly robust plants $5-30 \mathrm{~mm}$ long, (ii) a strong, often bulging limbidium that ceases well below the apex and is often intralaminar in the sheathing part, (iii) relatively large laminal cells (10-) 12-18 $(-20) \mu \mathrm{m}$ long and $6-12 \mu \mathrm{m}$ wide, and (iv) growing on basic rocks and stones in or near flowing water.

Variability: The above description of leaves refers to those of fully developed plants. Young shoots of small size can be observed where the limbidium is partly to completely reduced. Such plants should not be confused with (partly) elimbate aquatic species, e.g. F. arnoldii or F. exiguus.

Similar species:

F. gymnandrus: antheridia axillary, mostly naked, at most $200 \mu \mathrm{m}$ long, leaves wider, elliptical to obovate, 2-3 (-4) times as long as wide, leaf apex mostly obtuse, border nearly reaching leaf apex, archegonia 200-310 $\mu \mathrm{m}$ long, peristome teeth at their base $37-53 \mu \mathrm{m}$ wide (F. crassipes: antheridia always terminal, at least $250 \mu \mathrm{m}$ long, leaves lanceolate, 3-6 (-8) times as long as wide, leaf apex acute, border lacking at apex, archegonia 420-660 $\mu \mathrm{m}$ long, peristome teeth at their base 51-86 $\mu \mathrm{m}$ wide).

F. pusillus: plants usually smaller $(<5 \mathrm{~mm})$ with smaller laminal cells, (6-) 7-15 (-18) $\mu \mathrm{m}$ long; intralaminar limbidium lacking; archegonia (250-) 290-350 (-440) $\mu \mathrm{m}$ long; antheridia ca $200 \mu \mathrm{m}$ long; peristome teeth at their base (24-) $30-47(-53) \mu \mathrm{m}$ wide; usually growing on moist or wet, shaded siliceous rock in or near streams with clear water (F. crassipes: plants larger $(5-30 \mathrm{~mm})$ with larger laminal cells (10-) 12-18 (-20) $\mu \mathrm{m}$ long; intralaminar limbidium often present; archegonia 420-660 $\mu \mathrm{m}$ long, antheridia (190-) 260-400 (-450) $\mu \mathrm{m}$ long; peristome teeth at their base 51-86 $\mu \mathrm{m}$ wide; usually growing on \pm exposed calcareous stones or rocks near rivers and streams, often silt-incrusted).

F. rufulus: see note under that species.

Guerra and EderRa (2015) include F. mildeanus and F. crassipes subsp. warnstorfii in the synonymy of $F$. crassipes, but consider that this group of taxa deserves further research.

References: Limpricht (1890: 439-443), Demaret and Castagne (1959: 52-53, 69-72), BRuggeman-NANnenga (1982), NyHolm (1987: 8-9), BRUGGeman-NANnenga (1989: 77-80), Ahrens (2000: 99-101, 107-109), CortiNi Pedrotti (2001: 124-125), Smith (2004: 240-242, 251-252), GuerRA and EDERRA (2015: 168-170). 
Habitat and substrate: At or below normal water level on basic as well as (rarely) acidic rocks, rarely on wood (mostly on limestone, concrete, rarely on silt-covered tree bases), in inundated zone of streams and rivers or splash zone of waterfalls (often on calcareous stones of river embankment, on tufa near watermills). Moderately tolerant to pollution.

Associated bryophytes: Amblystegium tenax, Bryum moravicum, Calliergonella cuspidata, Cinclidotus fontinaloides, Cratoneuron filicinum, Didymodon sp., Fissidens arnoldi, Hygrohypnum luridum, Platyhypnidium riparioides, Rhynchostegium murale, Tortula muralis.

Vertical distribution: $90-375 \mathrm{~m}$ a.s.l.

Distribution in Hungary: (90 specimens, 33 grid cells, of which 20 represent recent finds). - Aggtelek Karst (7589.1) Borsod-Abaúj-Zemplén County, Aggteleki karst Mts, Kecső-patak at Jósvafö, N 48²9’ 04.4”, E 20³2’ 46.2”, 240 m, 23.08.2005, leg. B. Papp BP 180317. Börzsöny Mts (8079.2) Comit. Nógrád. In rupibus andesiticis umbrosis-humidis vallis rivi Rózsás-patak prope Királyháza montes Börzsöny, 31.07.1955, leg. L. Vajda, det. Potier de la Varde as Fissidens mildeanus BP 94203, 46456. Naszály (8180.4) Szendehely-Katalinpuszta, Lósipatak, Stein im ausgetrockneten Bachbett, oberh. Einmündung von Szendehely, 09.04.2007, leg. P. Szűcs and P. Erzberger (B-Erzberger 12168). Gerecse Mts (8375.2) Comit. Komárom. In locis irrigatis ad molam opp. Tóváros, $140 \mathrm{~m}$, 10.05.1942, leg. Á. Boros BP 94235. Vértes Mts (8475.4) Comit. Komárom. In

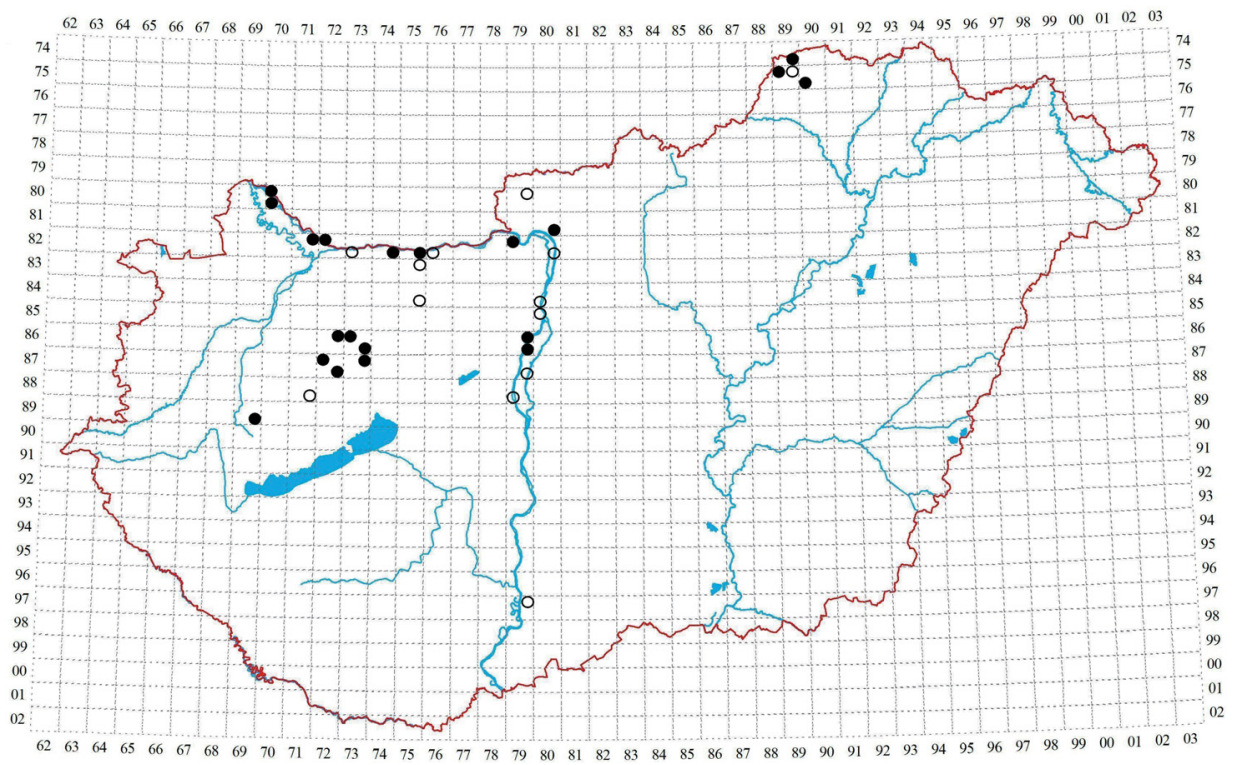

Fig. 10. Records of Fissidens crassipes. 
muris irrigatis calcareo-tophaceis molae ad pag. Környe, $150 \mathrm{~m}, 16.10 .1949$, leg. Á. Boros BP 94226, 94227, 94228, 94235, 78136 (also Cryptogamae exsiccatae editae a Museo Hist. Natur. Vindobonensi 3743). Bakony Mts (8773.2) Kom. Veszprém, Gaja-patak bei Bakonynána, auf Kalktuff im Bachbett, trock-

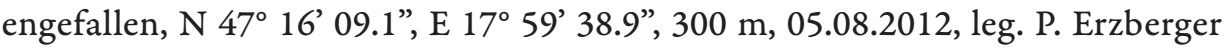
(B-Erzberger 15656). Danube inundation area (9779.2) Comit. Tolna. In rupibus calcareis irrigatis fluvii Danubii ad Korpádi-kanyar adversus Sükösd, 21.04.1954, leg. L. Vajda sub Fissidens crassipes var. mildeanus BP 27142, 27143, 27144, 94202.

On the map (Fig. 10) three regions seem to have most records: the embankment of the Danube, and streams in the Aggtelek Karst and Bakony Mts. However, this is probably at least in part an artefact, since these regions have been more thoroughly explored than others.

Distribution in adjacent countries: Occurring in all countries surrounding Hungary, but red-listed in some of them (Austria: 3, corresponding to EN, Romania: EN, Slovakia: EN - HodgetTs 2015).

Literature: In addition to the regions enumerated above and supported by vouchers in BP, Boros (1968) and ORBÁN and VAJDA (1983) mention Buda Mts, Balaton uplands, Köszeg Mts and Zala. They report the species from the Danube between Gönyü and Sükösd. PAPP (2009) published collections from the Aggtelek Karst that were seen by the author.

Red list status: LC (PAPP et al. 2010), which seems appropriate.

F. crassipes subsp. warnstorfii (M. Fleisch.) Brugg.-Nann. (=F. warnstorfii M. Fleisch., F. mouretii Corb., F. crassipes var. philibertii Besch., F. crassipes var. submarginatus $\mathrm{M}$. Fleisch. et Warnst.)

Plants robust, $2-5 \mathrm{~cm}$ tall, leaves $c a 1.5 \mathrm{~mm}$ long and ca $0.5 \mathrm{~mm}$ wide, elongate-lingulate, usually oblong, less often elliptical, apex subobtuse, obtuse to broadly acute, often with a weak apiculus, sometimes more narrowly acute; base of sheathing lamina narrow; apical lamina shorter than sheathing part, dorsal lamina mostly extending to leaf base, occasionally not reaching the base (CASAS et al. 2006); limbidium in sheathing part 10-23 $\mu \mathrm{m}$ broad, consisting of 4-6 rows of prosenchymatic cells, yellowish, becoming narrower and vanishing in apical part, dorsal lamina often completely elimbate, but sometimes in the middle with a short distinct limbidium of few elongate cells, sheathing part with intralaminar limbidium (i.e. a row of quadrate, chlorophyllose cells exists outside the border of narrow, hyaline cells); costa stout, yellowish green, percurrent; upper cells thin-walled, rich in chlorophyll, 9-12 $\mu \mathrm{m}$, at middle of dorsal lamina

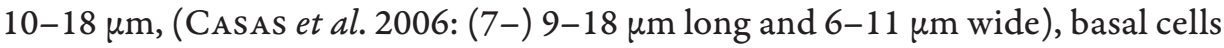
widened, quadrate and rectangular. 
Archegonia (260-) 280-420 (-450) $\mu \mathrm{m}$ long; peristome teeth 37-49 (-60) $\mu \mathrm{m}$ wide at base.

The differences between this taxon and $F$. crassipes subsp. crassipes concern variable characters, often with a wide overlap (e.g. length of archegonia or width of peristome teeth), which do not allow an unambiguous discrimination GUERRA and EDERRA (2015: 170). For example, in subsp. warnstorfii the apical part of the leaf is described as shorter than the sheathing part, but not rarely this is also true in subsp. crassipes. In subsp. warnstorfii the costa allegedly is percurrent, but sometimes also in subsp. crassipes. In subsp. warnstorfii the limbidium is reported to be often lacking in dorsal and upper parts, but an incomplete limbidium can often be observed also in subsp. crassipes, and both taxa frequently have an intralaminar limbidium in the sheathing part.

A critical taxon that probably needs further study.

References: LIMPRICHT (1904: 674-675), MÖNKEMEYER (1927: 139-140), Bruggeman-Nannenga (1982), Casas et al. (2001: 90-92), Cortini PedROtTi (2001: 125-126), CASAS et al. (2006: 119-120), Frahm in Frey et al. (2006: 164), GUERRA and EdERra (2015: 168-170).

Habitat and substrate: Similar to F. crassipes.

Distribution in Hungary: Not distinguished from F. crassipes subsp. crassipes and not mapped.

Distribution in adjacent countries: Reported from Slovenia only (redlisted as EN) among the countries surrounding Hungary; candidate for the new European red list (HODGETTS 2015).

Fissidens crispus Mont.

(= F. limbatus Sull., F. herzogii Ruthe ex Herzog, F. minutulus Sull. non auct. angl., F. cyprius Jur.)

(Figs 11, 12)

Plants growing in small patches, to $10 \mathrm{~mm}$ long and $3 \mathrm{~mm}$ wide, with (3-) 5-7 (-20) pairs of leaves; stems green to orange-red or dark reddish brown; leaves tightly crispate when dry, $0.5-2 \mathrm{~mm}$ long and $0.15-0.6 \mathrm{~mm}$ wide, $2-6$ times as long as wide, lingulate to narrowly lanceolate, acute, acuminate, or cuspidate, with concave sides at apex, to obtuse-apiculate; apical lamina shorter than sheathing part or of equal length or longer; dorsal lamina ending before insertion to decurrent; perichaetial leaves differentiated, a little longer and narrower to much longer than cauline leaves; margin denticulate at apex; limbidium present on all laminae, colourless, 1-2-stratose, $4-10 \mu \mathrm{m}$ wide, of 1-2 rows of cells, incomplete in depauperate specimens, in upper leaves ending below apex to reaching apex and confluent with costa, very wide and often intralaminal in sheathing 
part; limbidium of dorsal lamina rarely reaching stem; costa ending in or 1-3 cells below apex, infrequently short excurrent; laminal cells irregular in shape and size, locally bistratose, (3-) 4-8 (-10) $\mu \mathrm{m}$ wide in middle of apical lamina, strongly bulging on both surfaces of upper leaves in well-developed plants, usually arranged in \pm discernible rows, about twice as high as wide in cross section.

Synoicous, autoicous or dioicous. Archegonia terminal, ca $240 \mu \mathrm{m}$ long; when autoicous, antheridia borne on short basal branches or rarely in small ax-

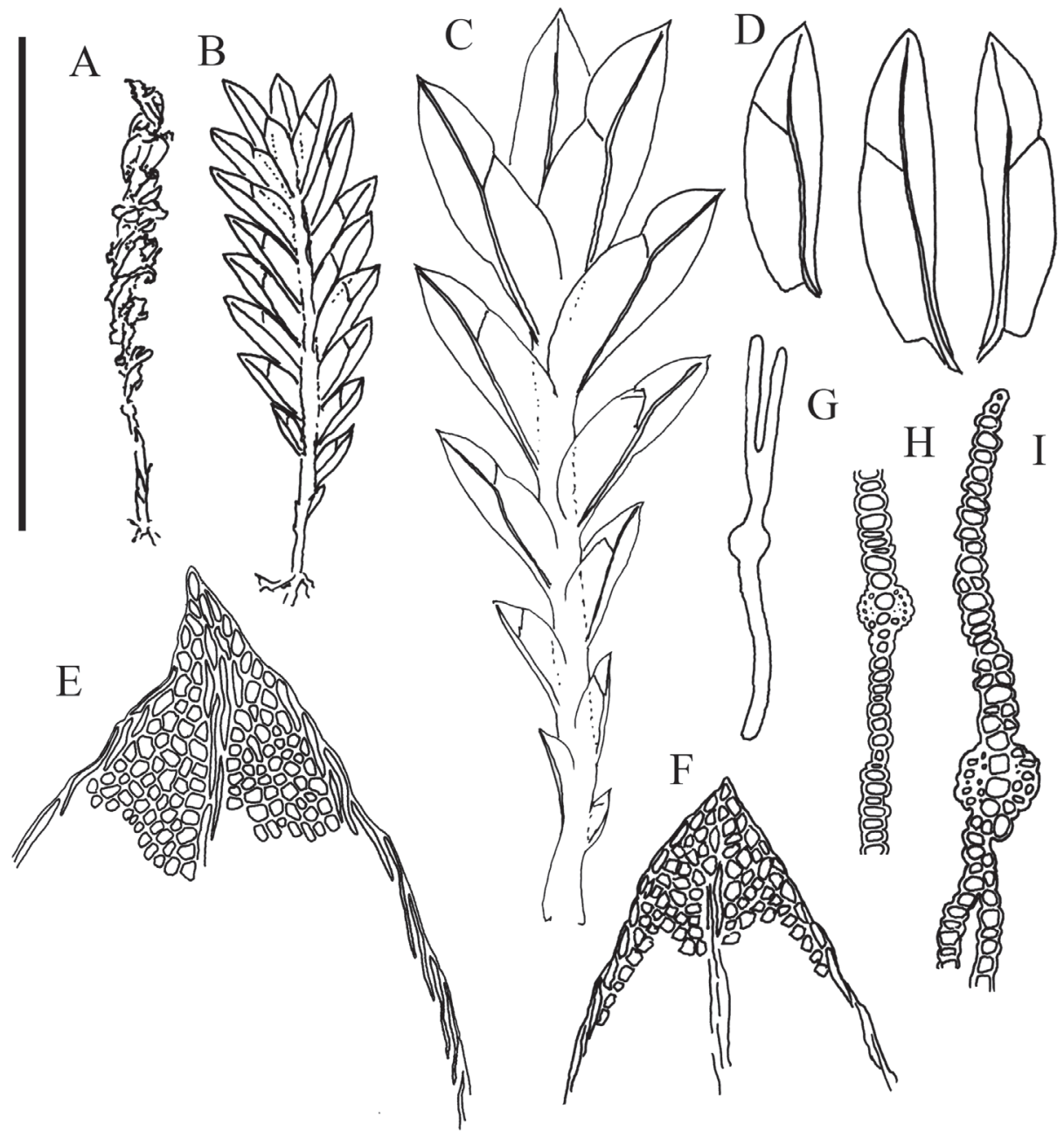

Fig. 11. Fissidens crispus: $\mathrm{A}=$ habit (dry); $\mathrm{B}, \mathrm{C}=$ habit (moist); $\mathrm{D}=$ leaves; $\mathrm{E}, \mathrm{F}=$ leaf apices; $\mathrm{G}$, $\mathrm{H}, \mathrm{I}=$ transverse sections of leaves. Scale bar: A, B: $-4.6 \mathrm{~mm}$; D: $-2 \mathrm{~mm}$; G: $-400 \mu \mathrm{m}$; E, F, H, I: $-200 \mu \mathrm{m}$ [A, B, D, F, G, I: B Bryo 283291 (Peru det. R. A. Pursell), C, E, H: BP 94288 (Hungary leg. L. Vajda 1957)]. 
illary buds; antheridia ca $120-180 \mu \mathrm{m}$ long. Sporophytes common (in $50 \%$ of specimens seen).

Seta terminal, yellowish to red, thick, 2-6 (-9) mm long; capsule erect and symmetric or less frequently slightly curved to horizontal and asymmetric, ellipsoid, urn ca $0.6(-1) \mathrm{mm}$ long; peristome teeth $21-55.5 \mu \mathrm{m}$ wide at base, filaments slightly papillose, with spiral thickenings; spores 8-18 $\mu \mathrm{m}$, yellow, smooth.

This small species is characterised by (i) leaves tightly crispate in the dry state, (ii) small laminal cells that are strongly bulging on both faces and about twice as high as wide in transverse section, arranged in \pm discernible rows.

Similar species:

F. ovatifolius: dorsal lamina not reaching leaf base; leaves broad ovate-elliptic to broad oblong, < 2.5 times as long as wide; median laminal cells not or only slightly protuberant, as high as wide in transverse section (F. crispus: dorsal lamina usually extending to the leaf base; leaves oblong to ovate-lanceolate, $>2.5$ times as long as wide, median laminal cells distinctly protuberant on both sides, higher than wide).

F. bambergeri: dry leaves usually not crispate; laminal cells not bulging, less than twice as high as wide in cross section; limbidium usually confined to vaginant laminae or variously reduced in lower leaves, often intralaminar ( $F$. crispus: dry leaves usually crispate; laminal cells strongly bulging on both faces and about twice as high as wide in cross section; limbidium usually developed on all laminae in mature leaves, rarely intralaminar).

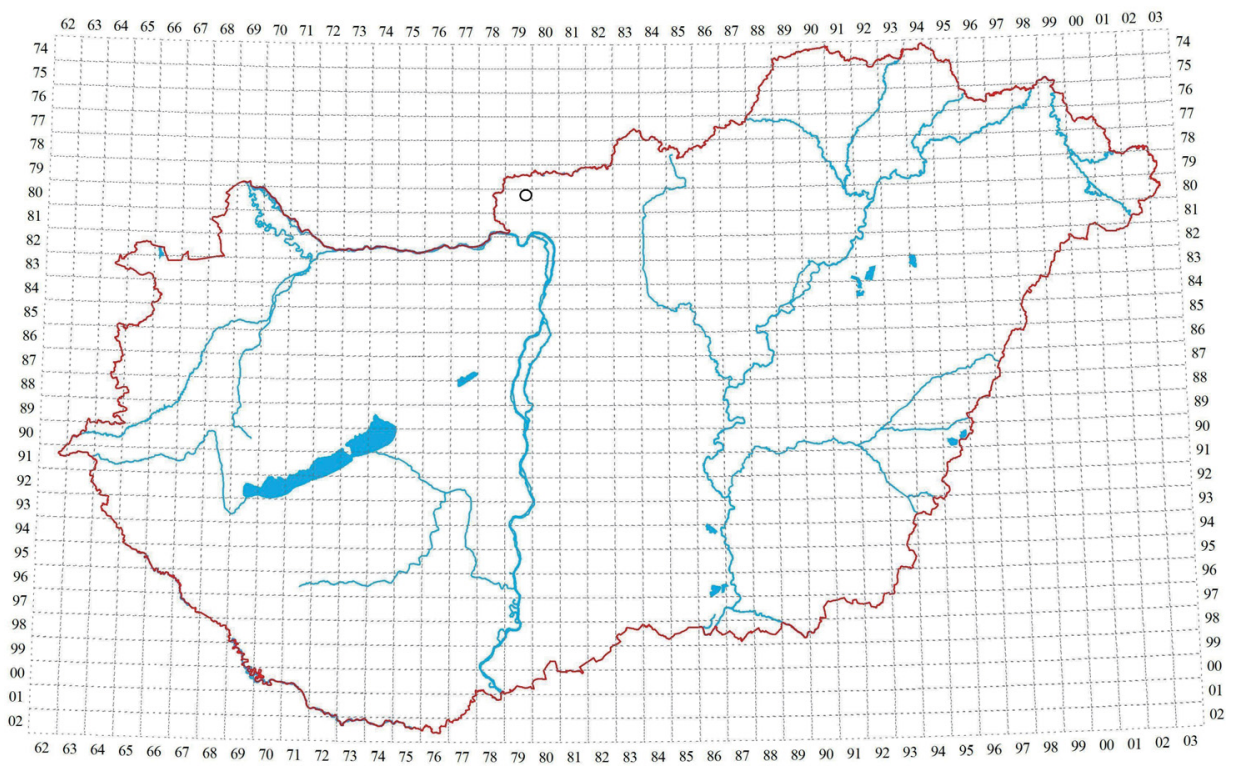

Fig. 12. Record of Fissidens crispus. 
F. gracilifolius, F. pusillus, F. viridulus: see the notes under these species.

References: LIMPRICHT (1890: 435-436 as F. cyprius Juratzka, fide Frahm in Frey et al. 2006), Corley (1980), PURSEll (1994a: 40-42, 51-52), Pursell (1994b: 31-34, 57-59, 61-62), Cortini Pedrotti (2001: 133-134), Smith (2004: 240-242, 244-246), FREY et al. (2006: 163), Bruggeman-Nannenga in HILL et al. (2006), CASAs et al. (2006: 118, 120), Pursell (2007: 349), Atherton et al. (2010: 404).

Habitat and substrate: On basic to slightly acid soil in woods, on ditch and stream banks, and on limestone or sandstone in sheltered but not wet sites, lowland.

Associated bryophyte: Thamnobryum alopecurum.

Vertical distribution: ca 450-700 $\mathrm{m}$ a.s.1.

Distribution in Hungary: (2 specimens, 1 grid cell, without recent finds). Börzsöny Mts (8079.2) Comit. Nógrád, In rupium fissuris vallis rivi Rózsapatak, prope Királyháza, montes Börzsöny 03.06.1957, leg. et det. L. Vajda (BP 58911 sub Fissidens mildeanus c. fr.) [note: L. Vajda. Levélsejtjei csak 8-10 $\mu$ m nagyok. Középér és erős szegély a hegy előtt elenyészik, levélszárnya a levéltövéig ér. Felső levelek tövében paraphysisek vannak. (= laminal cells only 8-10 $\mu \mathrm{m}$. Costa and strong border vanish below apex. Dorsal lamina extends to leaf insertion. At the base of upper leaves there are paraphyses.)]; Comit. Nógrád. In rupibus humidis ad margines rivi Dosnyapatak pr. Királyháza, mtes Börzsöny 30.06.1956, leg. et det. L. Vajda (BP 49725/b sub Fissidens pusillus).

Distribution in adjacent countries: Occurring in all countries adjacent to Hungary except Austria; EN in Slovenia, DD in Slovakia (Hodget ts 2015).

Literature: ERZBERGER (2016), not mentioned in the Hungarian bryological literature up to now.

Red list status: Until more records of this species become known, it must be considered data deficient (DD).

Note on taxonomic status: The synonymy of $F$. minutulus and $F$. crispus is controversial between North American and European authors (BruggemanNannenga in Hill et al. 2006, ann. 96).

\section{Fissidens curvatus Hornsch.$$
\text { (=F. algarvicus Solms) }
$$

(Figs 13, 14)

Plants growing in small patches or as scattered decumbent plants, 1.5-3 $(-10) \mathrm{mm}$ long, stems unbranched or branched from older parts, dimorphic: fertile stems with 3-5 pairs of leaves, to $5 \mathrm{~mm}$ long and to $2.0 \mathrm{~mm}$ wide (PURSELL 1994a: 1.2-5 mm long and ca 1-2 mm wide), sterile stems with as many as 25 
leaves, to $1 \mathrm{~cm}$ long and to $2.5 \mathrm{~mm}$ wide (PURSELL 1994a: to $\mathrm{ca} 5 \mathrm{~mm}$ long and $\mathrm{ca}$ $1.5 \mathrm{~mm}$ wide); leaves linear lanceolate, to $1.9 \mathrm{~mm}$ long and to $0.3 \mathrm{~mm}$ wide, gradually tapering from below middle to acuminate apex, dorsal lamina ending at or above leaf insertion, infrequently \pm decurrent, vaginant laminae $0.5-0.8$ of total leaf length; limbidium on all laminae, stout, 2-3-stratose, wide, confluent with costa at apex or ending shortly below apex, extending to base of dorsal lamina; costa percurrent to short excurrent; laminal cells papillose or smooth (see note below), thin-walled, in upper part of leaf irregular, narrowly hexagonal, about twice as long as wide, slightly elongate, 7-22 $\mu \mathrm{m}$ long and 4-9 (-13) $\mu \mathrm{m}$ wide, 4-8 $\mu \mathrm{m}$ wide in apical lamina, cells in sheathing lamina larger.

Dioicous, archegonia and antheridia terminal, male plants minute, bud-like. Sporophytes not rare (in $50 \%$ of specimens seen).

Seta red, 3-12 mm long, geniculate at base; capsules erect to inclined, symmetric to asymmetric, to $1.25 \mathrm{~mm}$ long, ovoid; lid to $0.3 \mathrm{~mm}$ long, rostrate; peristome teeth deeply divided, finely papillose below, spirally-thickened-papillose above; spores 11-18 $\mu \mathrm{m}$, smooth to finely papillose.

This small species is characterised by (i) leaves gradually tapering from below middle to acuminate apex, and (ii) laminal cells about twice as long as wide.

Additional characters (PURSELL 1994a): small size, dimorphic stems, leaves of fertile stems usually much larger than those on infertile stems; limbidium con-

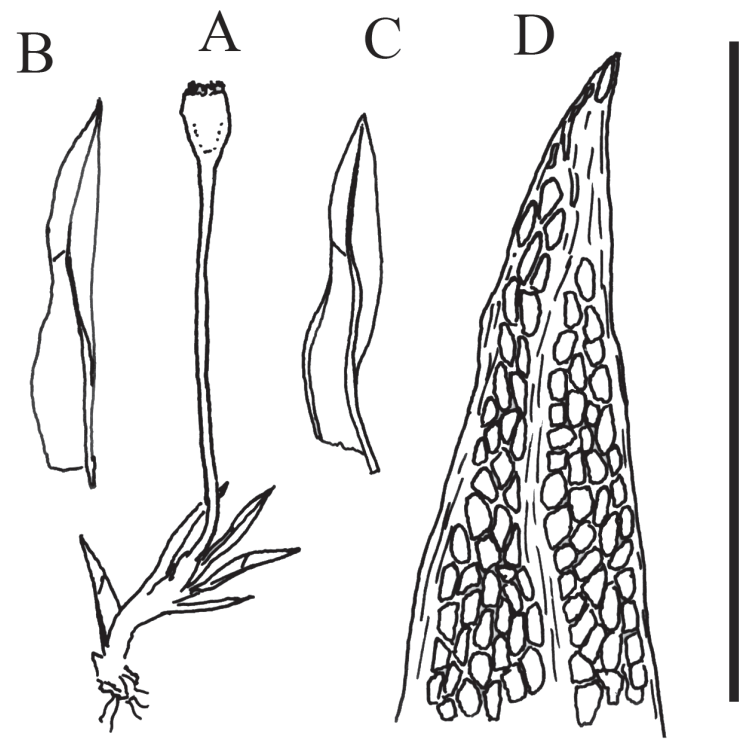

Fig. 13. Fissidens curvatus: $\mathrm{A}=$ habit; $\mathrm{B}, \mathrm{C}=$ perichaetial leaves; $\mathrm{D}=$ leaf apex. Scale bar: A - $3.8 \mathrm{~mm}$; B, C - $1.2 \mathrm{~mm}$; D - $200 \mu \mathrm{m}$ [BP 46459]. 
fluent with the short-excurrent costa; small inconspicuous axillary hyaline nodules also present.

References: Limpricht (1904: 671), Pursell (1994a: 40-42, 52-53, 1994b: 31-34, 62-63), BRUgGeman-NANNENGA and Pursell (1995), CASAS et al. (2001: 91), Cortini Pedrotti (2001: 120, 123-124), Müller and Pursell (2003), Smith (2004: 241, 254-255), PURSELl (2007: 347).

Habitat and substrate: On clayey soil on shaded banks.

Associated bryophytes: None.

Vertical distribution: ca 400-425 m a.s.1.

Distribution in Hungary: (2 specimens representing a single collection, 1 grid cell, not found recently). - Börzsöny Mts (8080.1) Comit. Nógrád. In argillosis ad margines rivi Kemencepatak prope pag. Diósjenő, montes Börzsöny, 25.09.1955, leg. et det. L. Vajda BP 94664, 46459 (conf. B. Papp 2004).

Distribution in adjacent countries: Only in Croatia and Slovakia (CR) among the countries surrounding Hungary; listed in the European red data book (ECCB 1995) in the category K (insufficiently known); candidate for the new European red list (HodgETTS 2015).

Literature: VAJDA (1956).

Red list status: DD-va.

Note on taxonomic status and variability: According to BRUGGEMANNANnenga and Pursell (1995), F. algarvicus is a new synonym of F. curvatus,

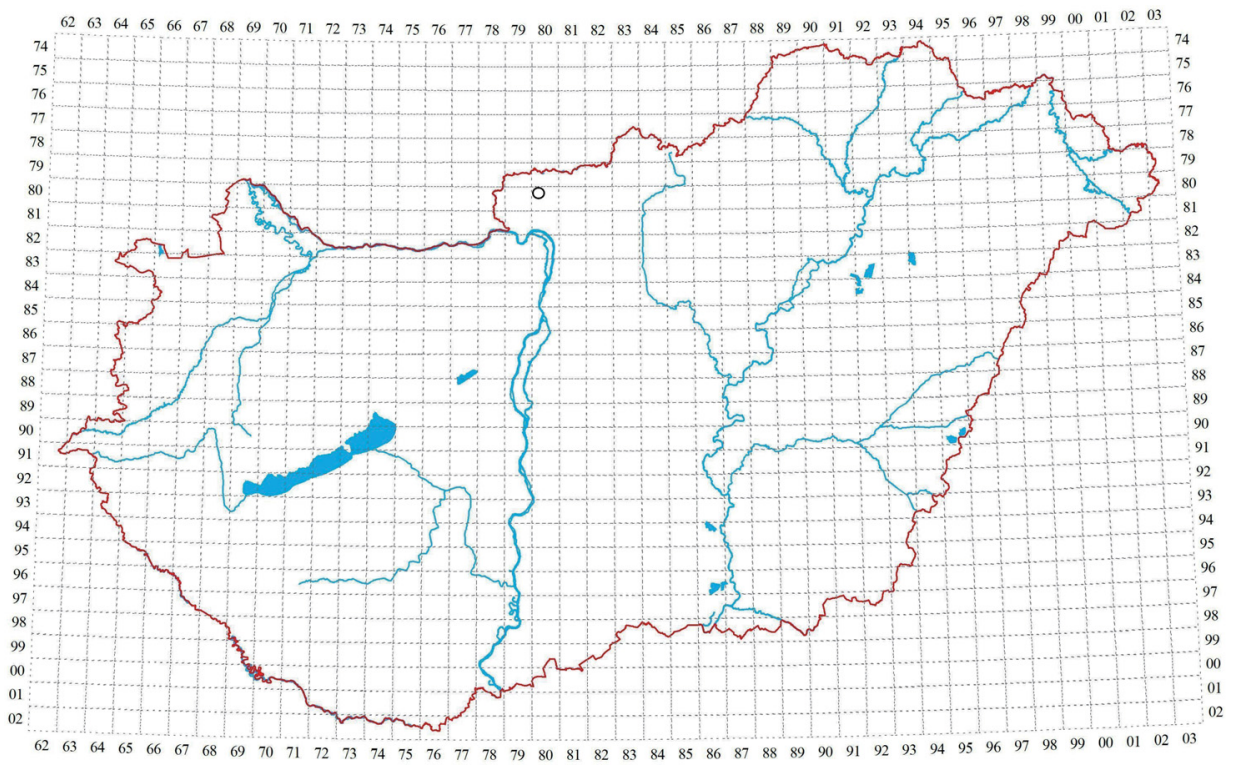

Fig. 14. Record of Fissidens curvatus. 
a highly variable taxon, obviously also with respect to laminal cell papillosity; laminal cells are described as "large,..., with widely spaced, minute papillae"; but this seems to be contradicting the later statement that "most collections have smooth laminal cells". Müller and Pursell (2003) and Pursell (2007) describe the laminal cells as smooth.

Fissidens dubius P. Beauv.

(= F. cristatus Wilson ex Mitt., F. decipiens De Not., F. rupestris Wilson, F. velenovskyi Podp.)

(Figs 15, 16)

Plants robust, growing in \pm dense, yellowish green to green, sometimes brownish turf, little branched, 1-3 (-6) cm long, erect, rarely decumbent; rhizoids brown; leaves in numerous pairs (10-35), $2(-3.4) \mathrm{mm}$ long and $0.5-1.0 \mathrm{~mm}$ wide, when dry mostly falcate with their top incurved towards the substrate, straight and sometimes slightly undulate when wet, ovate lanceolate to lingulate lanceolate, mostly suddenly narrowed to a short, acute to obtuse apex, sometimes mucronate; apical lamina mostly shorter than vaginant laminae, dorsal lamina reaching leaf insertion or slightly decurrent along stem; elimbate, leaf margin in upper part of leaf coarsely, sharply and irregularly dentate (in small plants only at the uppermost leaves), in lower part regularly crenulate, 3-4 (-5) rows of marginal cells (not differing in size and shape from laminal cells) more incrassate and pellucid, not bulging, forming a \pm conspicuous pale band (of 4-6 rows in vaginant laminae); costa stout, 50-62.5 $\mu \mathrm{m}$ wide at mid leaf, ending shortly below leaf apex or - var. mucronatus (Limpr.) Waldh. - (in uppermost leaves) shortly excurrent; lamina \pm opaque, apical and dorsal laminae nearly always with small bistratose spots, otherwise unistratose, cells bulging, in upper part of leaf irregularly to rounded hexagonal, 6-12 (-14) $\mu \mathrm{m}$ long (measured in the direction of their greatest extension).

Rhizoidal tubers, \pm spherical, $300-700 \mu \mathrm{m}$ in diameter, colourless when young, turning dark red to nearly black when old, sometimes present near the base of plants.

Dioicous or (rarely) autoicous, archegonia and antheridia usually in short, foliate, bud-like axillary branches, but antheridia may also occur in bud-like dwarf plants growing on the female plants. Sporophytes occasional, infrequent (in $10 \%$ of specimens seen).

Seta lateral, originating in the middle or the lower part of the stem, pale reddish, thick, flexuose, to $c a 1(-2) \mathrm{cm}$ long; capsules suberect to inclined and slightly curved, oblong ovate to ellipsoid, $1-1.5(-2) \mathrm{mm}$ long, contracted below mouth; lid about as long as the urn, longly rostrate with a \pm straight beak; peri- 


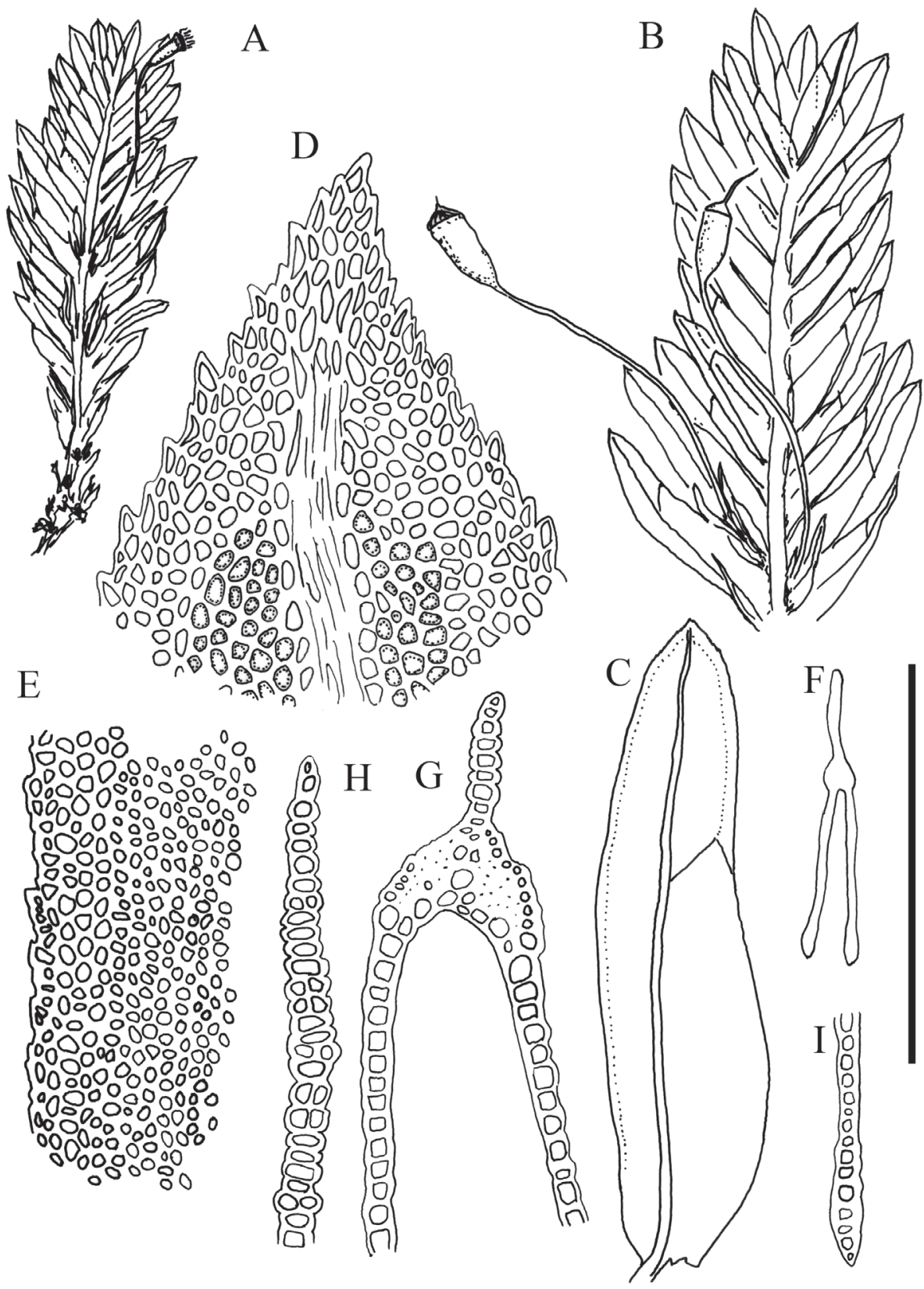

Fig. 15. Fissidens dubius: $\mathrm{A}, \mathrm{B}=$ habit of plants with sporophytes; $\mathrm{C}=$ leaf; $\mathrm{D}=$ leaf apex; $\mathrm{E}=$ margin of dorsal lamina at mid leaf; $F=$ transverse section of leaf; $G=$ transverse section of costa; $H=$ transverse section of dorsal lamina partially bistratose; $\mathrm{I}=$ transverse section of vaginant lamina. Scale bar: A - 11.7 mm; B - 7.33 mm; C - 2 mm; D, E, G, H, I - $200 \mu \mathrm{m}$; F - $800 \mu \mathrm{m}$ [Erzberger 12115]. 
stome teeth to $120 \mu \mathrm{m}$ wide at base, upper portion of filaments slightly papillose, without spiral thickenings; spores $10-15(-20) \mu \mathrm{m}$, finely papillose to nearly smooth, ripening from late autumn to spring.

This medium-sized to robust species is characterised by (i) leaves lacking limbidium on all laminae, (ii) margin differentiated by a pale band of 2-3 rows of incrassate cells, crenulate below and coarsely serrate to dentate at apex, at least in uppermost leaves, (iii) by small, bulging laminal cells usually $<10 \mu \mathrm{m}$ wide, often bistratose in patches, and, when present, (iv) the seta originating in the middle of the stem or below.

Similar species:

F. adianthoides, $F$. taxifolius: see the notes under these species.

References: Limpricht (1890: 425-426, 451-452), Demaret and CASTAGNe (1959: 52-53,79-81), NYHOLM (1987: 8, 13-14), BRUGGEMAN-NANNENGa (1989: 87-88), Ahrens (2000: 99-101, 109-110), Cortini Pedrotti (2001: 138-140), Allen et al. (2004), Smith (2004: 240-243, 256-258), CASAs et al. (2006: 124), Guerra and Ederra (2015: 182-184).

Habitat and substrate: In forests as well as in grassland, on calcareous substrates, on rocks and in rock crevices, sometimes on soil; most frequently on limestone and dolomitic rock, rarely on base-rich siliceous rocks, e.g. basaltic, diabasic or andesitic rock, phyllite, on sandstone, rarely on tree bases (Alnus: BP 59522), on rotting tree stumps (e.g. BP 93494).

Associated bryophytes: Amblystegium confervoides, Amphidium mougeotii, Anomodon attenuatus, $A$. viticulosus, Atrichum angustatum, $A$. undulatum, Barbilophozia barbata, Bartramia ithyphylla, B. pomiformis, Brachythecium glareosum, B. populeum, B. velutinum, Bryoerythrophyllum recurvirostrum, Bryum argenteum, B. capillare, B. moravicum, Campylium calcareum, C. chrysophyllum, Cephalozia bicuspidata, Ceratodon purpureus, Cololejeunea calcarea, C. rossettiana, Cratoneuron filicinum, Ctenidium molluscum, Cynodontium polycarpon, Dicranum scoparium, Distichium capillaceum, Ditrichum flexicaule, Encalypta streptocarpa, E. vulgaris, Eurhynchium hians, E. striatulum, E. striatum, Fissidens bambergeri, F. bryoides, F. gracilifolius, F. taxifolius, F. viridulus, Frullania tamarisci, Gymnostomum aeruginosum, G. calcareum, Homalia besseri, H. trichomanoides, Homalothecium philippeanum, $H$. sericeum, Hypnum cupressiforme, $H$. lacunosum, Isothecium alopecuroides, Jungermannia leiantha, Leiocolea collaris, Lejeunea cavifolia, Lophocolea minor, Lophozia excisa, Metzgeria conjugata, M. furcata, Mnium marginatum, M. stellare, Myurella julacea, Neckera complanata, N. crispa, Pedinophyllum interruptum, Plagiobryum zierii, Plagiochila porelloides, Plagiomnium cuspidatum, P. rostratum, Plagiopus oederianus, Plagiothecium nemorale, P. succulentum, Pleuridium subulatum, Pleurochaete squarrosa, Poblia andalusica, P. cruda, Porella arboris-vitae, P. platyphylla, Pottia lanceolata, Radula complanata, Reboulia hemisphaerica, 
Rhizomnium punctatum, Rhynchostegiella tenella, Saelania glaucescens, Scapania aequiloba, S. aspera, S. calcicola, Schistidium lancifolium, Taxiphyllum wissgrillii, Thamnobryum alopecurum, Thuidium abietinum, Th. delicatulum, Th. philibertii, Th. recognitum, Tortella tortuosa, Tortula schimperi, T. subulata, Trichostomum crispulum, Tritomaria exsecta, T. quinquedentata, Weissia brachycarpa, W. controversa.

Vertical distribution: $100-875 \mathrm{~m}$ a.s.l.

Distribution in Hungary: (422 specimens, 97 additional field data, 158 grid cells, of which 102 represent recent finds) documented for all regions except Cserehát Hills, Aggtelek Siliceous Landscape, Putnok Hills, Velence Mts, Fertő Hills, Örség, Hetés, Göcsej, Belső-Somogy, Zselic, Külső-Somogy, Hanság, Tiszántúl, Northern Plain, Dráva-sík, and Danube inundation region. Possibly the species can be found in some of these as well. The map is still very incomplete, it indicates different intensity of bryological research rather than frequency of occurrence, although the nearly complete absence of records from the lowlands probably has a real background. The quotation of specimens seems unnecessary.

Distribution in adjacent countries: Present in all countries surrounding Hungary, and not red-listed in any of them.

Literature: Boros (1968) reported the species from additional regions, e.g. Cserehát Hills, Fertő Hills, Örség, for which no vouchers were found in BP.

Red list status: Least concern (LC).

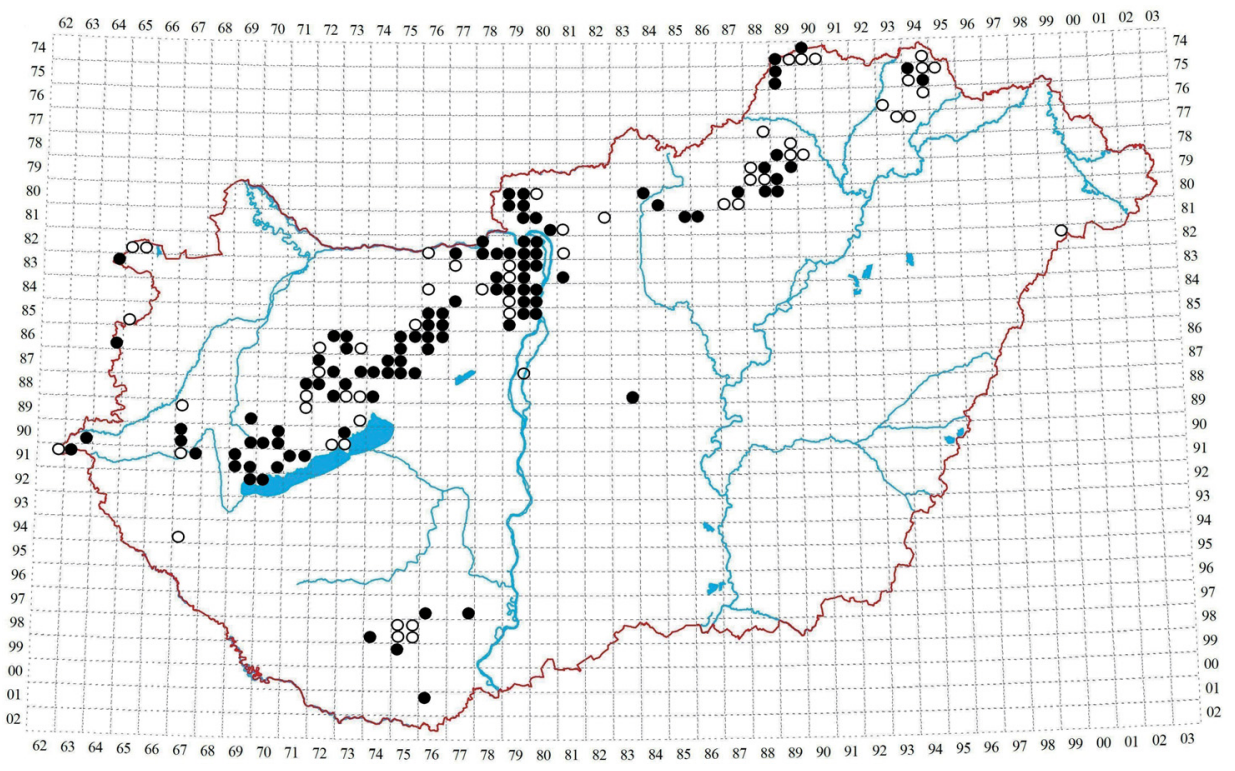

Fig. 16. Records of Fissidens dubius. 


\section{Fissidens exiguus Sull. \\ (=F. subimmarginatus $\mathrm{H}$. Philib.)}

(Figs 17, 18)

Plants solitary or growing in lax or dense, small patches, pale green, light green or yellowish green; only a few, to $6 \mathrm{~mm}$ long, mostly unbranched; leaves in 3-8 pairs, upper leaves distinctly larger than lower leaves, perichaetial leaves longer and narrower than cauline leaves, to 5 times as long as wide; leaves ovatelanceolate, lingulate-lanceolate or oblong-lanceolate, rather suddenly narrowed to a short apex; apical lamina of about the same length or slightly longer than vaginant laminae, dorsal lamina vanishing at leaf insertion or not reaching stem; leaf margins entire, limbidium \pm developed only in sheathing part of leaves, only in sheathing part of perichaetial and exceptionally of subperichaetial leaves, otherwise indistinct, incomplete or lacking, unistratose; costa ending somewhat below leaf apex; lamina unistratose, laminal cells in upper part of leaf rounded and irregularly hexagonal, ca 8-12 (-18) $\mu \mathrm{m}$ in the middle of apical lamina.

Dioicous; male plants slightly smaller than female plants; antheridia and archegonia terminal. Sporophytes frequent, spring (in 33\% of specimens seen).

Seta terminal, reddish, only few, to ca $5 \mathrm{~mm}$ long, thick, geniculate at base; capsule erect and symmetric to slightly inclined, oblong ovate to ellipsoidal, contracted below orifice; lid conical, rostrate; spores ca (10-) 12-16 (-20) $\mu \mathrm{m}$, nearly smooth.

This small hydrophilous species is characterised by (i) leaves lacking limbidium on all laminae except vaginant laminae of perichaetial leaves, but sometimes limbidia formed to a variable extent in uppermost leaves, (ii) smooth margin, (iii) leaf apex \pm acute, and (iv) habitat: growing on moist sandstone and volcanic rocks near streams.

Similar species:

F. viridulus: plants terricolous, never on wet or submerged stones or rock, usually larger; usually with \pm well-developed limbidium (F. exiguus: saxicolous, growing near water, plants smaller; limbidium mostly confined to sheathing part of perichaetial leaves).

F. bambergeri: plants terricolous; dorsal lamina not reaching stem; limbidium often intramarginal on vaginant laminae; plants polyoicous, often with a synoic inflorescence ( $F$. exiguus: saxicolous, \pm aquatic; dorsal lamina normally extending to leaf base; limbidium not intramarginal on vaginant laminae; plants dioicous).

F. pusillus: plants larger, cauline leaves limbate (F. exiguus: plants smaller, cauline leaves elimbate).

F. exilis: limbidium lacking on all laminae, margin crenulate (coarsely in sheathing part); plants growing on open soil in deciduous woods (F. exiguus: limbidium present only on vaginant laminae of perichaetial leaves, margin \pm entire; plants hydrophilous on acidic rocks). 
A

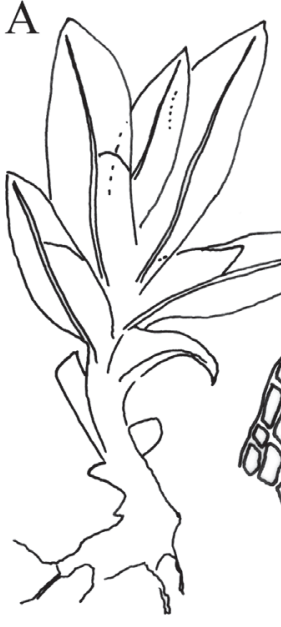

$\mathrm{B}$

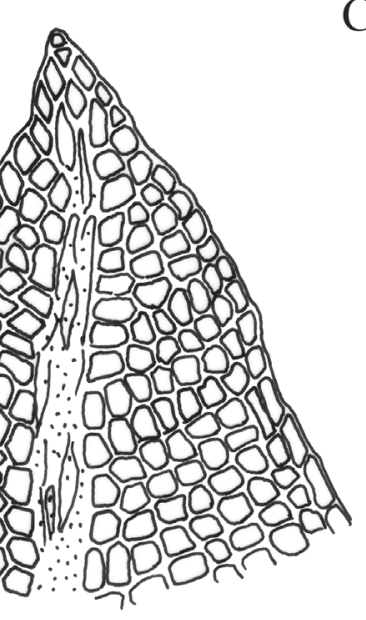

C

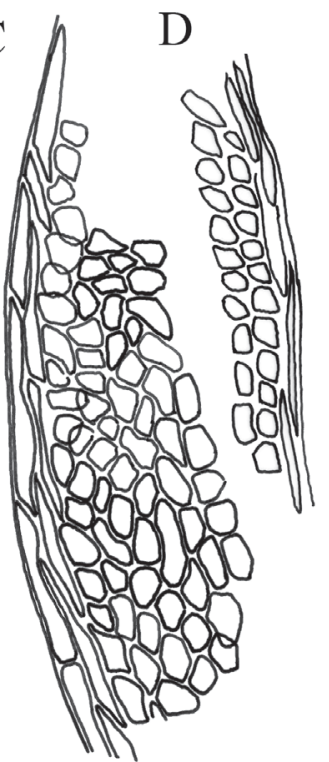

$\mathrm{E}$

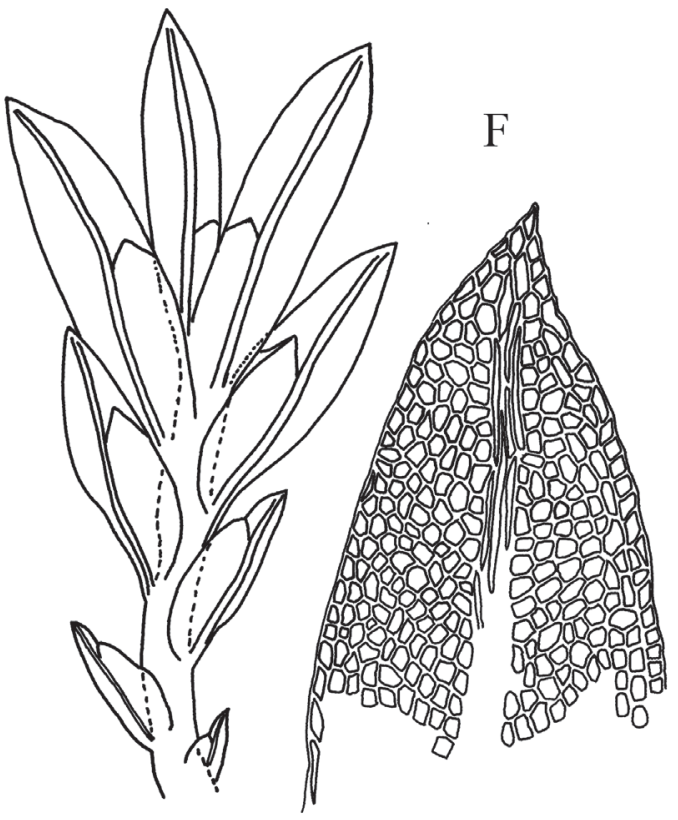

G

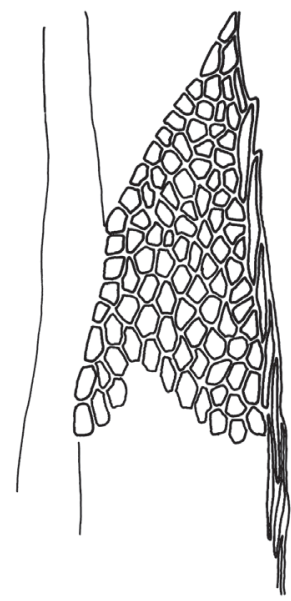

Fig. 17. Fissidens exiguus: $\mathrm{A}=$ habit; $\mathrm{B}=$ leaf apex; $\mathrm{C}=$ margin of vaginant lamina in subperichaetial leaf; D = margin of dorsal lamina at mid leaf in perichaetial leaf. Scale bar: A $-4 \mathrm{~mm}$; B, C, D $-200 \mu \mathrm{m}$ [JE Meinunger s.n. (Germany, leg. W. Schröder 2002)] Fissidens pusillus (poorly limbate): $\mathrm{E}=$ habit; $\mathrm{F}=$ leaf apex; $\mathrm{G}=$ margin of vaginant lamina. Scale bar: $\mathrm{E}-800 \mu \mathrm{m} ; \mathrm{F}, \mathrm{G}-200 \mu \mathrm{m}[\mathrm{BP}$ 94288 (Hungary, leg. Á. Boros 1945)]. 
F. arnoldii: apex obtuse to rounded, margin crenulate; growing on base-rich igneous or calcareous rock ( $F$. exiguus: apex acute, margin entire; growing on sandstone).

References: Limpricht (1904: 674), AHRENS (2000: 99-101, 110-111), Cortini Pedrotti (2001: 135-137), Smith (2004: 241, 243).

Habitat and substrate: On shaded wet or submerged acidic rocks in streams and rivers.

Associated bryophytes: None.

Vertical distribution: Unknown.

Distribution in Hungary: (3 specimens representing a single old collection, 1 grid cell). - Börzsöny Mts (8079.2) Comit. Nógrád. In rupibus humidis rivi Dosnyapatak prope Királyháza, montes Börzsöny, 17.06.1957, leg. L. Vajda BP 59127, 59128, originally det. Potier de la Varde as F. kosaninii, 1.4.1973 rev. Zd. Pilous as F. exiguus; BP 94658 is a duplicate in the Boros herbarium that was not seen by Pilous, it is also F. exiguus (conf. Th. Homm 2016).

Distribution in adjacent countries: Information is incomplete, since it has not been recognised as a distinct species by some recent authors (see below), therefore it is missing in checklists. In Austria, it is included in the synonymy of F. viridulus (KÖCKINGER et al. 2011), reported from Romania (ŞTEFĂNUȚ and GoiA 2012) and Ukraine (IgNATOV et al. 2006); listed in the European red data book (ECCB 1995) in the R (rare) category; omitted in HodgetTs (2015).

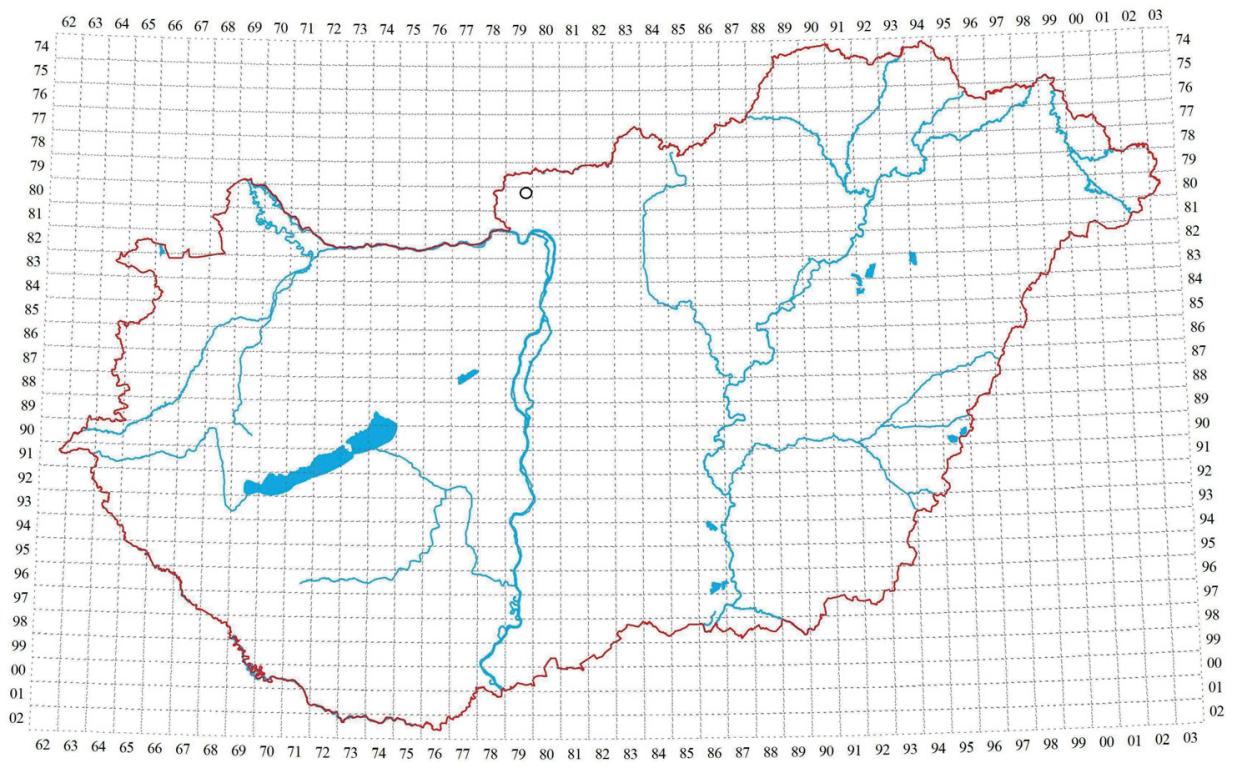

Fig. 18. Record of Fissidens exiguus. 
Literature: VAJDA (1958, 1975); PAPP and ERZBERgER (2003); ERZBERGER and PAPP (2004).

Red list status: In PAPP et al. (2010) considered CR, but this was based on a specimen recently collected in Aggtelek Karst (BP 164392) and here revised to $F$. arnoldii. Amended status: Data deficient (DD).

Note on taxonomic status: According to Bruggeman-Nannenga in HiLL et al. (2006), "Limbidia can be greatly reduced in many limbate species. Most taxa that are primarily or only characterised by their limbidia restricted to the vaginant lamina, e.g. Fissidens kosaninii Latzel, F. exiguus Sull. and F. viridulus var. intralimbatus (R. Ruthe) Düll, are probably just poorly limbate forms of limbate species" (Ann. 92). "European specimens identified as F. exiguus are poorly limbate forms of either F. viridulus or F. pusillus. F. exiguus is treated by North American authors as an expression of F. bryoides" (Ann. 103).

MeInUnger and SCHRÖdER (2007) do not accept this view and treat $F$. exiguus as a species in its own right, as does also AHrens (2000). According to these German authors, F. exiguus is also characterised by growing on humid or temporarily inundated rocks, contrary to the terricolous $F$. viridulus. See also SMITH (2004): "A reasonably good species, although almost impossible to separate from small forms of $F$. viridulus with poorly developed leaf border except by habitat, F. viridulus never occurs on wet or submerged stones or rock. Aquatic forms of $F$. pusillus are much larger with a well-developed border on the stem leaves.” (p. 243). “...has been much confused with F. viridulus var. lylei Wilson, which is merely a small form of F. viridulus." (Smith in Hill et al. 1992: 185).

I have provisionally confirmed some Hungarian specimens as $F$. exiguus according to the above-mentioned criteria. However, there are also specimens, which appear to belong to other limbate taxa (e.g. F. pusillus) with a limbidium much and to a variable extent reduced (e.g. BP 94288 - see Fig. 16E, F, G). In a note to another specimen (Börzsöny Mts (8079.2) Comit. Hont. In rupibus andesit. silvat. alvei rivi Kemence-patak infra Barsi-bükk pr. Kemence 300 m, 12.10.1958, leg. Á. Boros BP 94659), the collector comments on this in detail: "Levele szélén a szegély (limbus) csökevényes, egyes leveleken a lev. egyik szélén hiányzik, a másikon alig kivehető, más leveleken mindkét szélén felismerhető. Levele szélesebb mint a $F$. kosaninii-é, mely utóbbi levelei keskenyek, megnyúltak. A levél alakja azonban a F. pusillus-nál nagyon változó. A Barsi-bükk alatt szedett moha csaknem megegyezik a F. valiae rajzával (Rev. Bryol. 15. 1945. p. 34.), mely Bizot és Pierrot szerint azonos a F. kosaninii-vel (Rev. Bryol. 34: 1966. p. 707.) Növényem a F. pusillus és a kosaninii közt átmenet. 1969. febr. 16. Boros" (Translation: The border (limbus) at the leaf margin is rudimentary, on some leaves it is lacking completely on one of the margins, on others hardly discernible, and on still others recognisable on both margins. The leaf is broader than that of F. kosaninii, which latter has nar- 
row, elongate leaves. However, the leaf shape of $F$. pusillus is very variable. The moss collected near Barsi-bükk is almost identical to the drawing of F. valiae (Rev. Bryol. 15. 1945. p. 34.), which according to Bizot and Pierrot is identical with $F$. kosaninii (Rev. Bryol. 34: 1966. p. 707.) My plant represents a transition between F. pusillus and F. kosaninii. 16. febr. 1969 Boros).

An in-depth biosystematic study might resolve this controversial question.

\section{Fissidens exilis Hedw. (=F. bloxami Wils.)}

(Figs 19, 20)

Plants solitary or gregarious growing from persistent protonema, decumbent; green to yellowish green, only ca 1-3 mm long, stem of female plants 1-2.5 (-3) $\mathrm{mm}$ long, unbranched; rhizoids hyaline to light brown, slightly papillose; leaves in (2-) 3-4 pairs, perichaetial leaves (0.8-) $1.2-1.9(-2.1) \mathrm{mm}$ long and $0.2-0.4 \mathrm{~mm}$ wide, (2.5-) 3.8 times as long as wide; upper leaves much larger than lower leaves, upper leaves lingulate, oblong lanceolate or linear lanceolate, mostly suddenly narrowed to short and \pm acute apex, often obtuse mucronate or indistinctly acuminate; in upper leaves apical lamina often longer than vaginant laminae; dorsal lamina ending shortly to far above leaf base; margin elimbate, (but sometimes with some intramarginal elongate cells at the sheathing part), entire to finely and evenly serrulate or crenulate by protruding cell ends, without band of paler cells; margin of sheathing part in perichaetial leaves often \pm distinctly to coarsely dentate; costa stout, vanishing slightly below or in leaf apex, 35-45 $\mu \mathrm{m}$ wide at mid leaf; lamina unistratose, laminal cells in upper part of leaf plane, not bulging, irregularly hexagonal, (6-) 10-12 (-18) $\mu \mathrm{m}$ long (measured in the direction of their greatest extension), moderately incrassate, laminal cells at the middle of dorsal lamina (7-) 9-17 (-18) $\mu \mathrm{m}$ long and (6-) 10-12 (-18) $\mu \mathrm{m}$ wide, $8-12(-14) \mu \mathrm{m}$ wide in the middle of apical lamina; laminal cells in vaginant laminae large, rectangular, 16-39 $\mu \mathrm{m}$ long.

Autoicous or dioicous, male plants small, mostly dwarf and bud-like, at the base of female plants or solitary; archegonia ca 180-270 $\mu \mathrm{m}$ long, terminal; antheridia ca 90-120 $\mu \mathrm{m}$ long, terminal. Sporophytes frequent, usually present (in $73 \%$ of specimens seen).

Seta terminal, yellow to reddish, to $c a 8 \mathrm{~mm}$ long, flexuose, geniculate at base; capsules \pm erect and symmetric, sometimes slightly inclined, oblong ovate (subcylindrical) to ellipsoid, 0.5-1.0 mm long, strongly contracted below mouth; lid conical, rostrate, $0.4-0.6 \mathrm{~mm}$ long; peristome teeth at their base $30-39 \mu \mathrm{m}$ wide, filaments slightly papillose, with spiral thickenings; spores (8-) 10-15 $\mu \mathrm{m}$, finely papillose to nearly smooth, ripening late autumn to spring. 

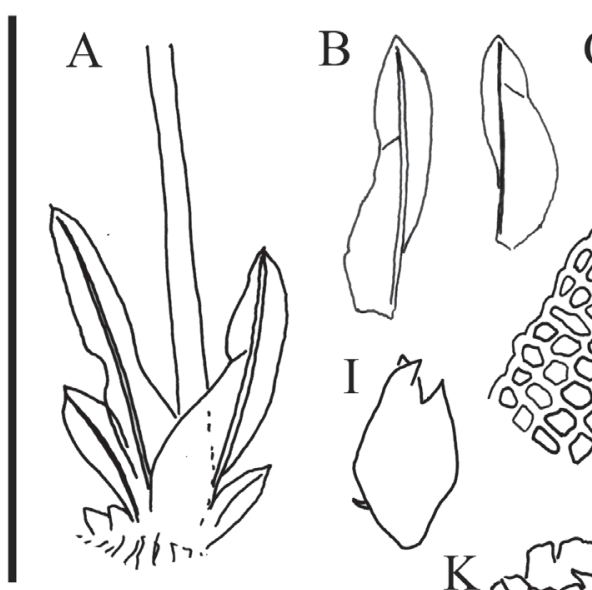

C

D

$\mathrm{F}$

0000
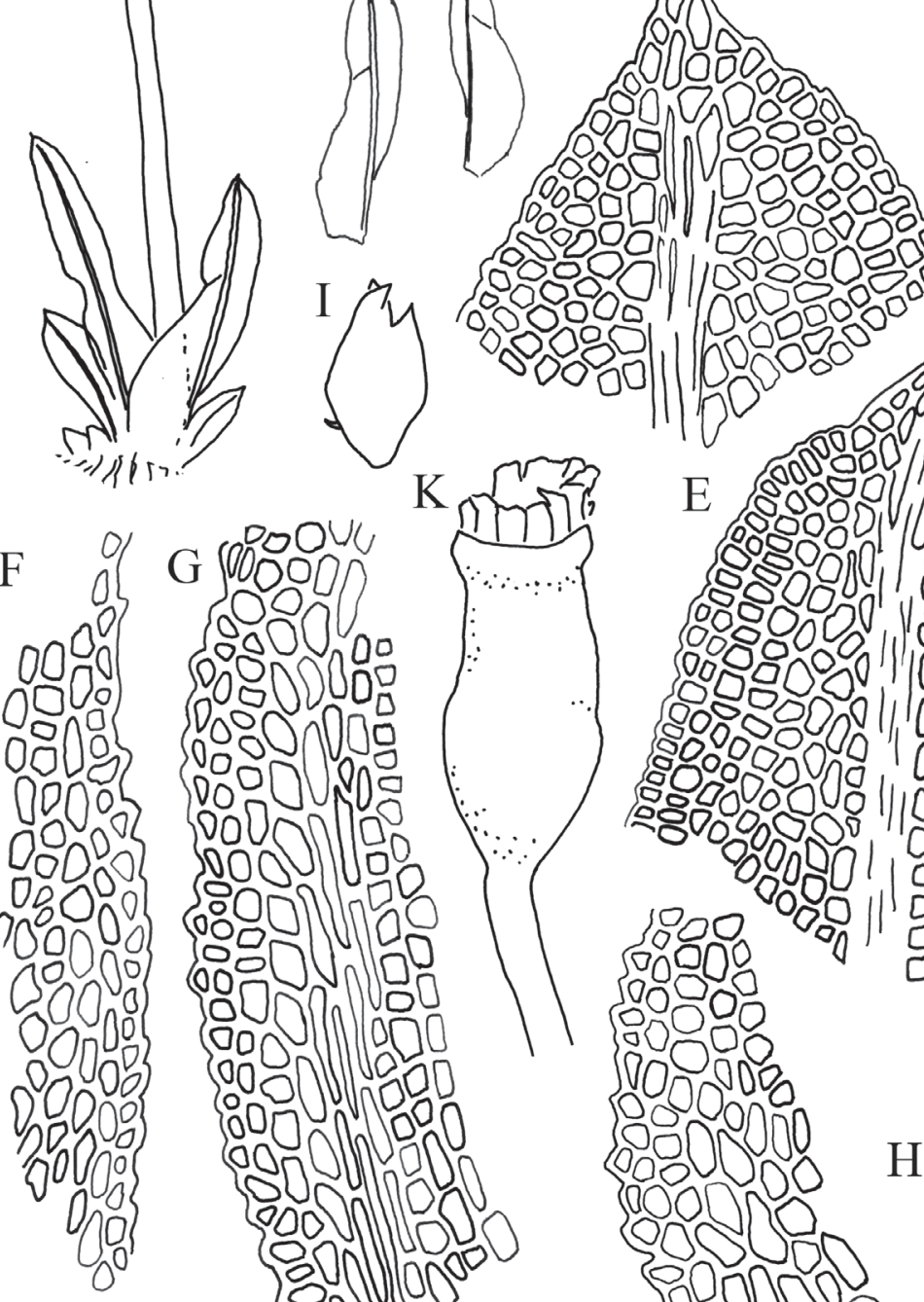

$\mathrm{J}$
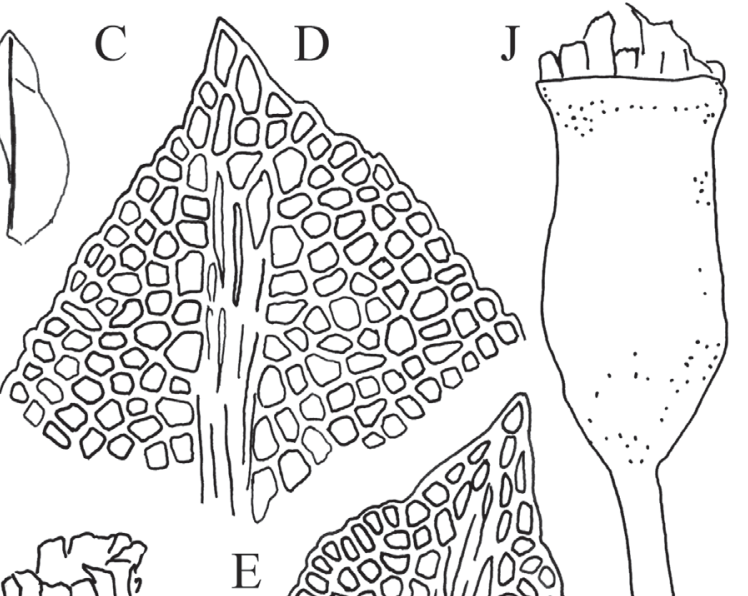

$\mathrm{E}$
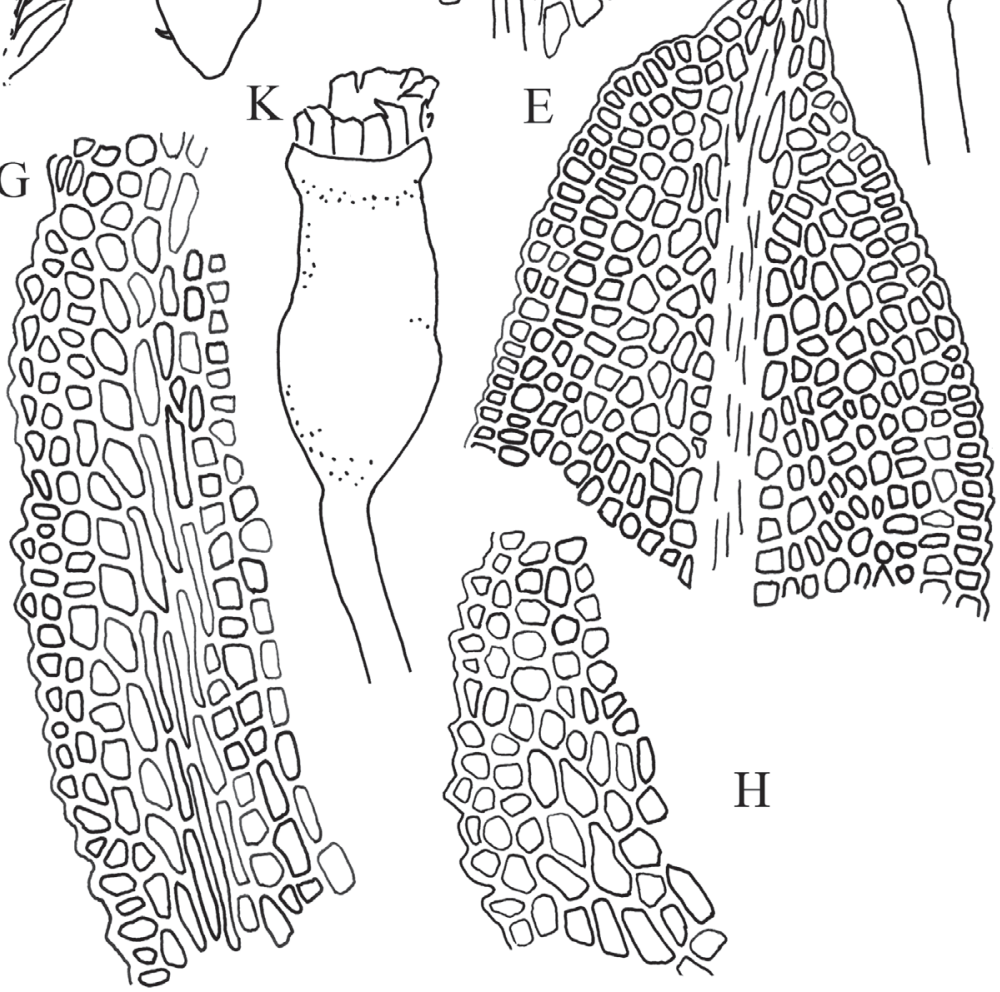

Fig. 19. Fissidens exilis: $\mathrm{A}=$ habit; $\mathrm{B}, \mathrm{C}=$ leaves; $\mathrm{D}=$ apex of subperichaetial leaf; $\mathrm{E}=$ apex of perichaetial leaf; $F=$ margin of vaginant lamina in perichaetial leaf; $G=$ margin of vaginant lamina in subperichaetial leaf with intralaminar elongate cells; $\mathrm{H}=$ margin of vaginant lamina in basal leaf; I = dwarf bud-like male plant; J, K = deoperculate capsules (dry). Scale bar: A, B, C - 4 mm; D, E, F, G, H - $200 \mu \mathrm{m}$; I, J, K - $800 \mu \mathrm{m}$ [Erzberger 12173]. 
This minute species is characterised by (i) its exceedingly small size, growing from permanent protonema, usually with perichaetial leaves only and with sporophytes, (ii) limbidium lacking on all lamina, (iii) marginal band not differentiated, margin finely crenulate to smooth, except on vaginant laminae, where it is \pm coarsely and irregularly dentate, (iv) apex acute, costa not excurrent, and (v) laminal cells incrassate, smooth, plane, not bulging.

Similar species:

F. arnoldii: leaves in 4-5(10) pairs, increasing in length towards stem apex, plants erect; sheathing part of leaves entire; plants growing on limestone or other base-rich rocks and stones in or near water (F. exilis: leaves in 2-4 pairs, plants procumbent; margin on sheathing part of perichaetial leaves often coarsely dentate; terricolous, nearly always with capsules).

F. taxifolius: usually a larger plant with numerous leaf pairs (>4); costa excurrent in stout point; laminal cells smaller, more rounded, bulging, lamina not translucent (F. exilis: small plants with up to 4 leaf pairs; costa vanishing below or in leaf point, not excurrent; lamina translucent, laminal cells larger, hexagonal, \pm incrassate, not bulging).

F. exiguus: see the note under that species.

References: Limpricht (1890: 422-426, 446-448), Demaret and CasTAGNe (1959: 52-53,74-75), NyHolm (1987: 8, 12-13), BRUG GEMAN-NANNENga (1989: 85), Ahrens (2000: 99-101, 112-113), Cortini Pedrotti (2001: 135-137), Allen et al. (2004), Smith (2004: 240-242, 252-254), Guerra and EDERRA (2015: 175-177).

Habitat and substrate: On clayey ground, on bare soil, on edges of ditches, beside streams, on open soil in deciduous woods.

Associated bryophytes: Atrichum undulatum, Brachythecium velutinum, Bryum rubens, Ceratodon purpureus, Dicranella heteromalla, Fissidens bryoides, F. taxifolius, Lophocolea heterophylla, Plagiomnium affine, Pleuridium subulatum, Tortula schimperi.

Vertical distribution: $120-850 \mathrm{~m}$ a.s.l.

Distribution in Hungary: (26 specimens, 25 additional field data, 39 grid cells, of which 26 represent recent finds). - Aggtelek Karst (7590.3) Comit. Borsod-Abaúj-Zemplén. In terra in sylvis in parte superior vallis Szén-völgy prope pag. Varbóc, 220 m, 30.05.1990, leg. M. Rajczy, det. B. Papp BP 166398. Bükk Mts (7989.2) Borsod-Abaúj-Zemplén County, Miskolc-Lillafüred, Szinvavölgy, yellow-marked path up north of Kerek-hegy, on soil near the forest road, N $48^{\circ} 05^{\prime} 10.1^{\prime \prime}$, E $20^{\circ} 37^{\prime} 00.2^{\prime \prime}, 470 \mathrm{~m}, 05.08 .2015$, leg. P. Erzberger and Cs. Németh (B-Erzberger 20327). Mátra Mts (8186.1) Comit. Heves. In rupibus andesit. sept. silvat. montis Saskő prope Parád, 850 m, 20.10.1951, leg. Á. Boros as admixture to F. taxifolius BP 93694. Börzsöny Mts (8079.2) Comit. Hont. In arenoso-argil- 
losis ad marg. silv. prope Királyháza, 400 m, 21.04.1958, leg. Á. Boros BP 94290. Visegrád Mts (8380.1) Comit. Pest. In rupibus andesit. umbr. silvat. ripae rivi inter mont. Kö-hegy et Nagycsikóvár prope Pomáz, 250 m, 10.06.1945, leg. Á. Boros BP 94287. Naszály (8180.4) Naszály, W-Seite, Wald, zwischen Wurzeln von Carpinus betulus, 09.04.2007, leg. P. Erzberger and P. Szücs (B-Erzberger 12173). Buda Mts (8479.4) Budapest, Hüvösvölgy, 07.04.1925, leg. J. Szepesfalvy BP 63684. Bakony Mts (8971.2-4) Com. Veszprém. Ad fossas in sylvestribus montis Kabhegy prope pag. Padrag, 05.10.1955, leg. L. Vajda BP 42521. Köszeg Mts (8665.1) Kőszeg, Kálvária kocsi útján. c.fr., 19.02.1933, leg. A. Visnya BP 94780 det. Á. Boros as F. bryoides (in fact, F. exilis represents an admixture to F. cf. viridulus). Vendvidék (9063.3) Vas County, Szakonyfalu, ridge between Grajka-patak valley and Szakonyfalvi-patak valley, on soil in mixed forest, $\mathrm{N} 46^{\circ}$ 54' 20.6”, E 16 14' 01.9”, 340 m, 31.07.2014, leg. P. Erzberger and Cs. Németh (B-Erzberger 18635, 18636). Örség (9164.3) County Vas. Örség region. On soil in a Fagetum in the forest Bükkös-erdő at Dávidháza, 18.04.2000, leg. B. Papp BP 167351. Zala (9568.1) Comitat Zala. In quercetis Alsó városi erdő dit. pr. opp. Nagykanizsa, 200 m. 08.02.1948, leg. Á. Károlyi BP 58334 det. Á. Boros. Zselic (9771.2 or 9772.1) Locus natalis: Cott. Somogy. Zselic. In silvis arenosis pinetis silv. cult. pr. pag. Lipótfa, 05.11.1957, leg. A. Borhidi BP 94279, det. Á. Boros. Mecsek Mts (9874.4) Comit. Baranya. In argilloso-schistaceis vallis Szuadó-völgy prope Orfü, 350 m, 28.06.1952, leg. Á. Boros BP 93595 (as admix-

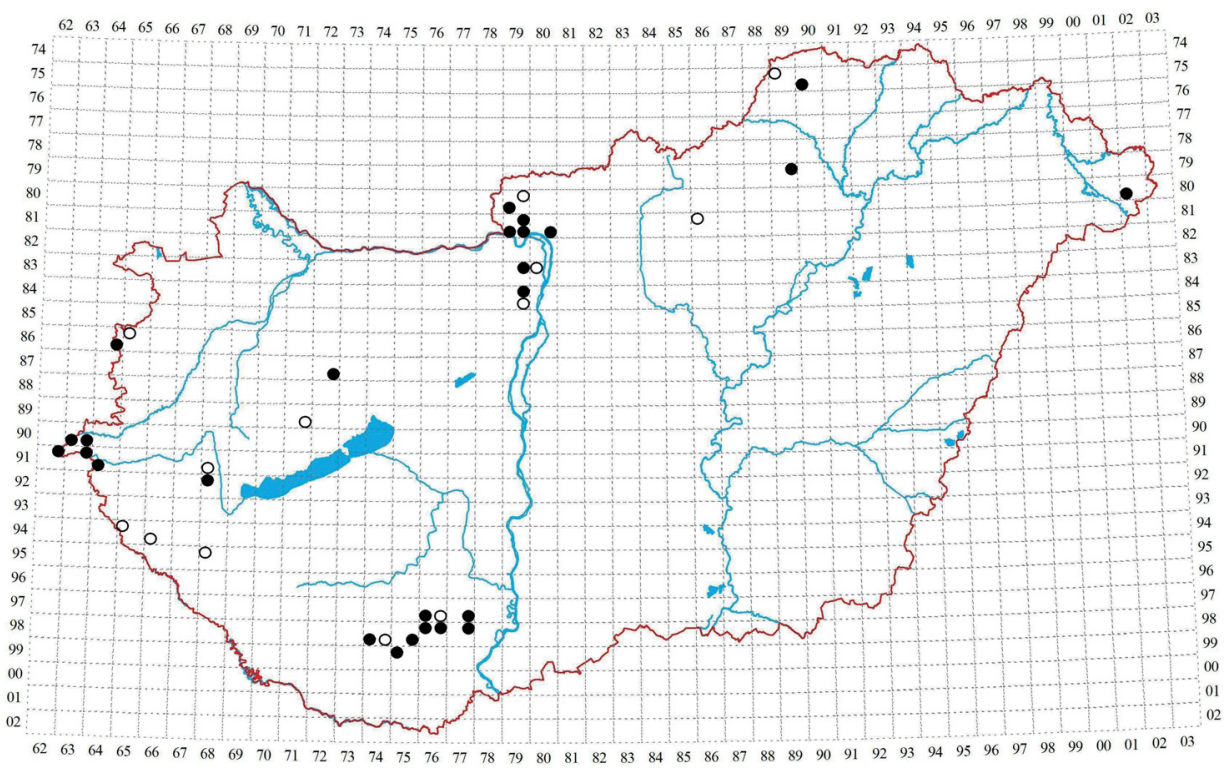

Fig. 20. Records of Fissidens exilis. 
ture to F. taxifolius). Northern Plain (8002.3) Szabolcs-Szatmár-Bereg County, Majtisi-erdő forest at Jánkmajtis, on soil, N 47 56' 17.0”, E 22 40’18.2”, 119 m, 05.08.2004, leg. B. Papp BP 171335.

The map (Fig. 20) is very incomplete and documents the present state of bryological exploration. Old records of this species are few and scattered over the whole country, recent records appear in greater density in areas that have been subject to more thorough recording.

Distribution in adjacent countries: Reported from all countries surrounding Hungary; red-listed in Austria (3, corresponds to EN), VU in Slovenia, NT in Romania and Slovakia (HodgetTs 2015).

Literature: Boros (1968) and ORBÁN and VAJDA (1983) report the species additionally from the Velence Mts, for which no voucher was found in BP.

Szücs et al. (2015) report F. exilis also from the Sopron Mts (8364.2).

Red list status: NT (PAPP et al. 2010), but according to the present data LC seems appropriate.

Fissidens fontanus (Bach. Pyl.) Steud.

(= Octodiceras fontanum (Bach. Pyl.) Lindb., F. julianus (Lam. et DC.) Schimp.)

Plants aquatic, dark green to blackish-green (young shoots light green), flaccid, in lax or dense groups floating submerged in water; stem lacking central strand; shoots to about $5(-10) \mathrm{cm}$ long, simple or branched several times, feather-like; leaves in many (20-60) pairs, distantly placed along the stem, spreading, linear to linear lanceolate, very long (to about $5 \mathrm{~mm}$ ), leaf apex narrow, subobtuse to obtuse; apical lamina about 2-3 times as long as sheathing part, dorsal lamina often not extending to leaf insertion; margins entire, without pale marginal band, limbidium lacking on all laminae; costa ending below leaf apex, 25-30 $\mu \mathrm{m}$ wide at mid leaf; lamina unistratose, cells in the middle of dorsal lamina irregularly rectangular, thin- or thick-walled, rich in chlorophyll, ca 10-14 $\times 8-10 \mu \mathrm{m}$, distinctly smaller ( ca $8 \mu \mathrm{m}$ wide) towards margins, base and apex, larger at costa, $15-25(-30) \times 11.5-14 \mu \mathrm{m}$.

Autoicous; archegonia terminal on short lateral, axillary branches, antheridia terminal on lateral, short, bud-like axillary branches, often male and female buds in the same leaf axil; sporophytes infrequent.

Seta originating at the top of short, axillary lateral branches, short $(<1 \mathrm{~mm})$ and thick (to $0.18 \mathrm{~mm}$ ), fragile, erect; capsules small, ca $0.5 \mathrm{~mm}$ long, erect, symmetric, ellipsoid, not exserted from stem leaves, without stomata, wide-mouthed; lid longer than the urn, conical, longly rostrate; peristome imperfect, teeth truncate, roughly papillose; spores ca $15-25 \mu \mathrm{m}$, finely papillose, yellowish to brownish. The capsules easily break off and float on the water. 
This aquatic plant usually growing submerged in slowly flowing water is characterised by (i) an apical part more than twice the length of the sheathing part, and (ii) narrow leaves up to 10 times as long as wide.

References: Limpricht (1890: 456-459), NyHolm (1987: 8, 13-14), Touw and Rubers (1989: 90), Ahrens (2000: 99-100, 126-128), Cortini Pedrotti (2001: 120, 122-123), Guerra and Ederra (2015: 173, 175, 178).

Habitat and substrate: On submerged rocks or roots, in standing or slowly flowing water, moderately pollution tolerant.

Distribution in Hungary: Not recorded. Boros (1968) mentioned the species as one to be expected, but it has hitherto been searched for in vain.

Distribution in adjacent countries: Reported from Austria, Romania, and Ukraine; red-listed in Austria (4, corresponds to risk assumed) and Romania (CR); candidate for the new European red list (HodGETTS 2015).

\section{Fissidens gracilifolius Brugg.-Nann. et Nyholm}

(=F. pusillus var. tenuifolius Boulay, F. viridulus var. tenuifolius (Boulay) A. J. E. Smith, F. pusillus var. minutulus (Sull.) Husn., F. minutulus auct. non Sull.)

(Figs 21, 22)

Plants gregarious or growing in mostly small, lax turf, green, very small, only up to $3(-5) \mathrm{mm}$ long, stems $2-3.5(-4.5) \mathrm{mm}$ long, mostly unbranched; leaves in $2-5(-7)$ pairs, upper leaves much larger than lower cauline leaves, leaves $0.8-1.3$ $\mathrm{mm}$ long and $0.1-0.3 \mathrm{~mm}$ wide, $3.5-8$ times as long as wide; perichaetial leaves 1.2-1.9 mm long, up to $8(-9)$ times as long as wide; leaves narrowly lanceolate to linear lanceolate, longly and sharply, often narrowly acuminate; apical lamina about as long as or longer than vaginant laminae; dorsal lamina extending to leaf insertion and decurrent along stem; margins entire or faintly denticulate near apex; limbidium narrow, unistratose, formed of 1-2 rows of cells, ending somewhat below or in the apex, in the middle of dorsal lamina 4-9 (-10) $\mu \mathrm{m}$ wide, sometimes poorly developed on dorsal lamina; costa percurrent or vanishing immediately below leaf apex, in perichaetial leaves shortly excurrent, 20-25 $\mu \mathrm{m}$ wide at mid leaf; lamina unistratose, cells in upper part of leaf irregularly hexagonal, ca (6-) 7-14 $\mu \mathrm{m}$ long (measured in the direction of their greatest extension), in the middle of dorsal lamina $6-14 \mu \mathrm{m}$ long and 3-9 $\mu \mathrm{m}$ wide.

Autoicous and dioicous, male plants small and bud-like or taller, at the base of female plants or solitary; archegonia 220-340 $\mu \mathrm{m}$ long, terminal; antheridia 150-220 $\mu \mathrm{m}$ long, terminal. Sporophytes very frequent, regularly present (in $65 \%$ of specimens seen).

Seta terminal, yellowish to reddish, thin, only 1.5-2.5 (-5) mm long; capsule erect, rarely slightly inclined, ovate to oblong-ovate, \pm symmetric, $0.4-0.7$ 
(-1.0) mm long, contracted below mouth; lid conical, obliquely rostrate, tall, sometimes more than half the length of the capsule; peristome teeth at their base 24-39 $\mu \mathrm{m}$ wide, filaments strongly papillose, with spiral thickenings; spores 9-17 $\mu \mathrm{m}, \pm$ smooth.

This species is characterised by (i) minute plants, $<5 \mathrm{~mm}$ long, growing firmly attached to \pm moist calcareous rock, (ii) limbidium ending below the nar-

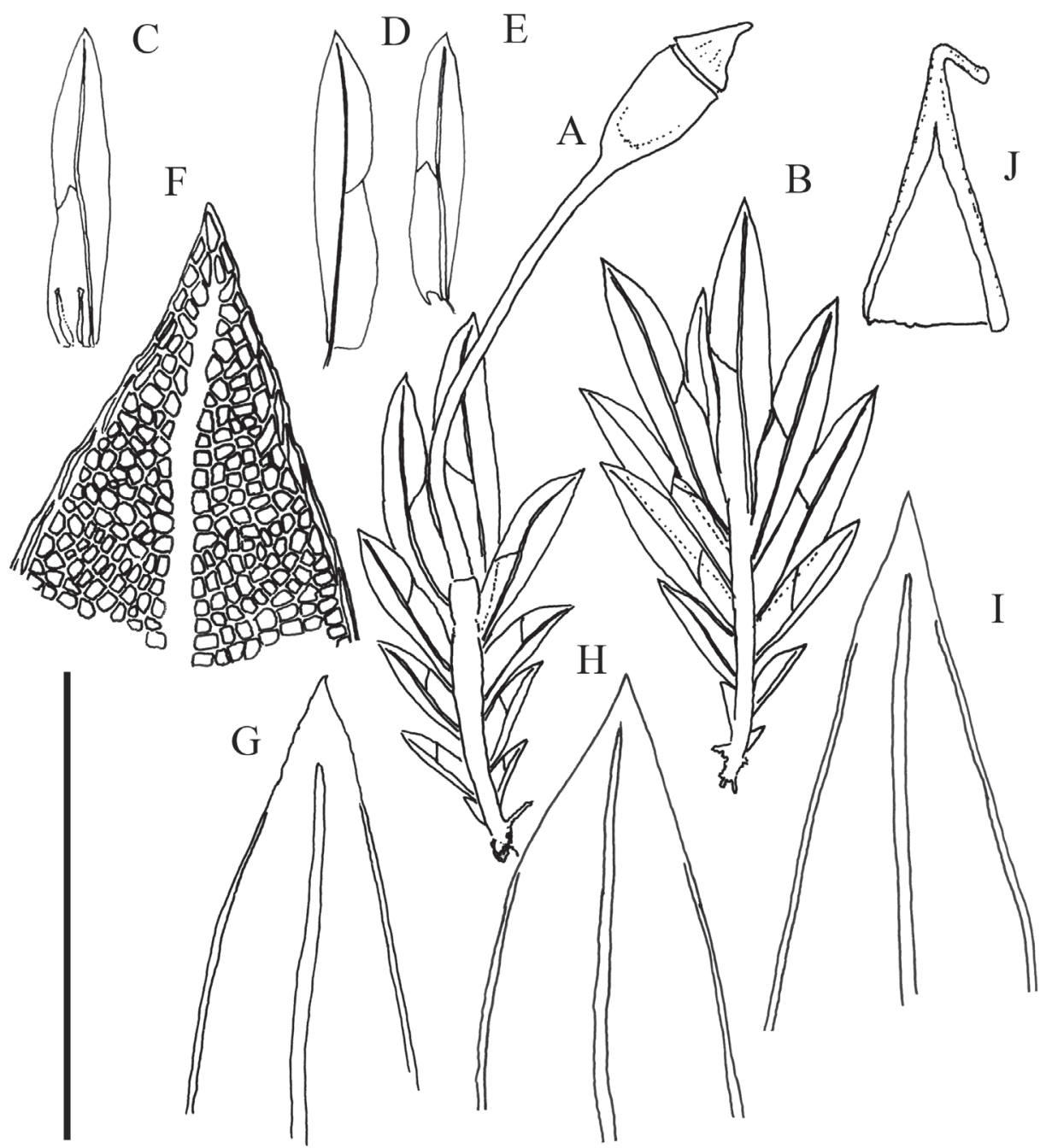

Fig. 21. Fissidens gracilifolius: $\mathrm{A}=$ habit of plant with sporophyte; $\mathrm{B}=$ habit of female plant; $\mathrm{C}, \mathrm{D}$ $=$ perichaetial leaves ( $\mathrm{C}$ with archegonia); $\mathrm{E}=$ subperichaetial leaf; $\mathrm{F}, \mathrm{G}, \mathrm{H}=$ leaf apices of perichaetial leaves; I = leaf apex of subperichaetial leaf; J = calyptra. Scale bar: A, B, C, D, E - 2 mm; F $200 \mu \mathrm{m} ; \mathrm{G}, \mathrm{H}, \mathrm{I}-400 \mu \mathrm{m} ; \mathrm{J}-800 \mu \mathrm{m}$ [Erzberger 16859]. 
rowly pointed, acuminate leaf apex, and (iii) by perichaetial leaves about 7 times as long as wide.

Similar species:

F. pusillus: leaves lanceolate, rather broad, 4-6 times as long as wide, suddenly narrowed to a short and wide, somewhat obtuse or \pm acute apex; plants hydrophilous, growing on siliceous rock often close to flowing water or inundated; archegonia slightly longer, (250-) 290-350 (-440) $\mu \mathrm{m}$ long (F. gracilifolius: leaves 4-8 times as long as wide, narrowly lanceolate to linear lanceolate, longly and sharply acuminate; plants growing on usually moist, shaded calcareous rocks, mostly non-hydrophilous; archegonia slightly shorter, 220-340 $\mu \mathrm{m}$ long).

F. crispus: dry leaves usually crispate; laminal cells very small, 6-8 $\mu \mathrm{m}$, strongly bulging on both faces and about twice as high as wide in cross section $(F$. gracilifolius: dry leaves not crispate; laminal cells larger, flat, not bulging, about as high as wide in cross section).

F. viridulus: see the note under that species.

References: Demaret and Castagne (1959: 52, 58-60), NyHolm (1987: 8-10), Bruggeman-NANnenga (1989: 77, 80), Ahrens (2000: 99-101, 113 114), Cortini Pedrotti (2001: 129, 131), Smith (2004: 240-242, 246, 247), GuERrA and EdERra (2015: 171-173).

Habitat, substrate: On wet or moist calcareous rocks, also in caves, sometimes on sandstone; but according to SMITH (2004: 247) "on dry chalk, especially small pieces, limestone and calcareous sandstone in woodland and sheltered habitats". This difference could well be related to the generally wetter climate of the British Isles.

Associated bryophytes: Amblystegium confervoides, $A$. serpens, A. tenax, Anomodon attenuatus, $A$. longifolius, $A$. viticulosus, Bryum moravicum, Campylium calcareum, Cololejeunea rossettiana, Didymodon fallax, D. sinuosus, Distichium capillaceum, Eucladium verticillatum, Eurhynchium hians, Fissidens dubius, Leptobryum pyriforme, Leptodictyum riparium, Leskea polycarpa, Mnium stellare, Pedinophyllum interruptum, Plagiomnium rostratum, Poblia cruda, Rhizomnium punctatum, Rhynchostegium murale, Seligeria pusilla, Seligeria sp., Taxiphyllum wissgrillii.

Vertical distribution: $150-920 \mathrm{~m}$ a.s.1.

Distribution in Hungary: (148 specimens, 70 grid cells, of which 36 are recent). - Aggtelek Karst (7489.4) Borsod-Abaúj-Zemplén County, Aggteleki karszt, Hideg kút spring in Ménes valley at Szelcepuszta. N 48 32'00.4”, E 20³8' 34.9”, 235 m, 09.09.2007, leg. B. Papp sub Fissidens pusillus BP 175430. Bükk Mts (7889.3) Comit. Borsod. In rupibus calcareis tophaceis silvat. vallis Alsósebes prope Ómassa, 500 m, 27.09.1952, leg. Á. Boros sub Fissidens pusillus BP 94616. Börzsöny Mts (8179.4) Comit. Nógrád. In rupibus umbrosis humidis vallis 11 
vályus, ad Törökmező, montes Börzsöny, 05.09.1954, leg. L. Vajda sub Fissidens pusillus BP 27977. Visegrád Mts (8278.2) Comit. Esztergom. In rupibus calcar. tophac. humidis umbrosis vallis Nyír-völgy prope Pilismarót, 260 m, 24.08.1952, leg. Á. Boros sub Fissidens pusillus BP 94571. Naszály (8180.4) Kom. Nógrád Grenze Pest, Stein im Bachbett des Lósi-patak bei Szendehely-Katalinpuszta, 09.04.2007, leg. P. Erzberger and P. Szücs (B-Erzberger 12160). Pilis Mts (8279.3) Comit. Pest. In rupibus calcar. umbros. sept. montis Vaskapu-hegy supra vallem Vaskapu-völgy prope Pilisszentkereszt, 550-600 m, 02.06.1946, leg. Á. Boros sub Fissidens pusillus BP 94534. Buda Mts (8479.3) Kom. Pest, Budaer Gebirge, Fekete-hegyek, Nagy-Kopasz, S-Seite, schattiger (Kalk-)Block, 15.04.2001, leg. P. Erzberger (B-Erzberger 6865). Gerecse Mts (8377.1) Comit. Esztergom. In cava rupium calcar. montis Sárási-kő prope Bajna, 300 m, 04.04.1949, leg. Á. Boros sub Fissidens pusillus BP 94520. Vértes Mts (8576.1) Kom. KomáromEsztergom, Várgesztes: Zsigmond-szikla, N 47²8’52.2”, E $18^{\circ} 24^{\prime} 01.4$ ”, 345 m, 19.10.2013, leg. Cs. Németh and P. Erzberger (B-Erzberger 16859). Bakony Mts (8673.1) Kom. Veszprém, Bakonyszentlászló, Alsó-Cuha-szurdok, Kalkstein im/ am Bach, N 47²2’ 44.4”, E 17 50’ 07.8”, 300 m, 26.05.2013, leg. Cs. Németh and P. Erzberger (B-Erzberger 16249). Balaton uplands (9071.3) Veszprém County, stream at Széles forrás near Monostorapáti, limestone rocks, N $46^{\circ} 56^{\prime} 13.8^{\prime \prime}, \mathrm{E}$ $17^{\circ} 34^{\prime}$ 52.3”, 170 m, 25.08.2012, leg. B. Papp sub Fissidens pusillus BP 186211. Keszthely Mts (9169.3) Kom. Zala, Rezi, Csóka-kő, schattige Dolomitfelsen,

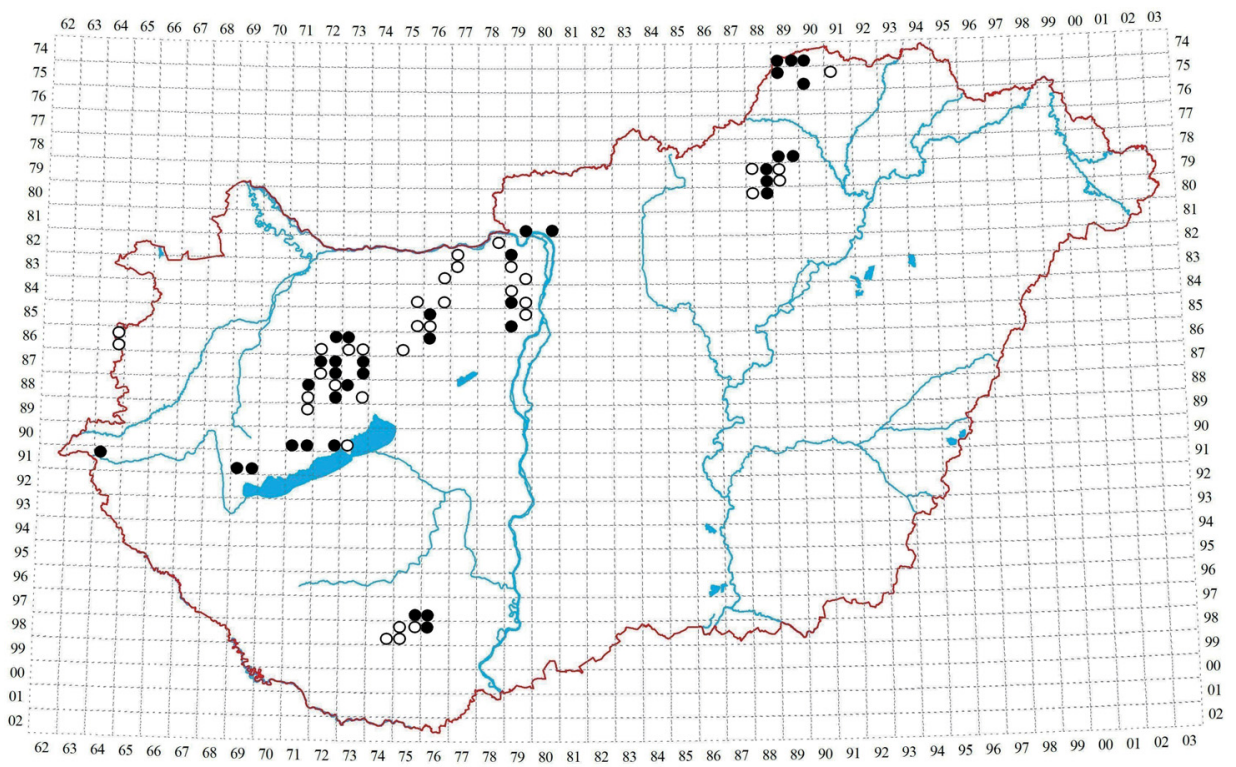

Fig. 22. Records of Fissidens gracilifolius. 
27.06.2013, leg. Cs. Németh and P. Erzberger (B-Erzberger 16431). Kőszeg Mts (8664.4) Comit. Vas. Ad saxa phyllit. in silvis montis Hát-hegy pr. Bozsok, $400 \mathrm{~m}$, 13.06.1970, leg. Á. Boros sub Fissidens pusillus BP 163710. Mecsek Mts (9875.3) Comit. Baranya. In rup. calcar. tophac. umbros. irrigatis vallis Nagymély-völgy prope Mánfa, 250 m, 06.04.1953, leg. Á. Boros sub Fissidens pusillus BP 94479.

The map (Fig. 22) shows the preference of calcareous bedrock, since the records are concentrated in those mountains (Aggtelek Karst, Bükk Mts) in the Northern Range, and in particular in the Transdanubian Mts (Pilis Mts, Buda Mts, Gerecse Mts, Vértes Mts, Bakony Mts, Balaton uplands, Mecsek Mts).

Distribution in adjacent countries: In all countries surrounding Hungary, but red-listed in Romania (VU) (Hodget s 2015).

Literature: Boros (1968) considered this taxon (as F. pusillus f. minutulus (Sull.) Mönkem.) as not sharply delimited from $F$.pusillus and did not give details of its distribution, but stated that it occurred mainly on calcareous tufa, whereas ORBÁN and VAJDA reported it mainly from moist limestone. Some of the records from Aggtelek Karst were published as F. pusillus (PAPP 2009).

Red list status: LC-att (PAPP et al. 2010), LC seems appropriate.

Note on taxonomic status: According to SMITH $(2004: 246,247)$,a poorly defined species which might be better treated as a variety of $F$. pusillus", since "it intergrades considerably with F. pusillus". However, Smith's opinion could be related to his broad concept of $F$. pusillus, including plants growing "on dry or wet chalk, limestone and sandstone", whereas continental authors consider F. pusillus a species \pm restricted to wet siliceous rocks.

Fissidens gymnandrus Büse

(三F. bryoides var. gymnandrus (Büse) Ruthe)

(Figs 23, 24)

Plants growing in lax or dense turf or in groups, mostly pale green to vivid green or dark green, 2.5-9 mm long, mostly simple; leaves in 4-8 pairs, 0.8-1.7 $\mathrm{mm}$ long and $0.3-0.65 \mathrm{~mm}$ wide, $2-3(-4)$ times as long as wide; perichaetial leaves $1.2-2.2 \mathrm{~mm}$ long, leaves broadly lanceolate, ovate lanceolate, lingulate lanceolate to elliptical, suddenly narrowed to short, mostly obtuse, sometimes acute apex; apical lamina slightly shorter than vaginant laminae or of equal length, dorsal lamina extending to leaf insertion (AHRENS 2000) or not (BRUGGEMANNannenga 1989), decurrent (Cortini Pedrotti 2001); margins entire or indistinctly denticulate at apex, limbidium well developed, consisting of 3-4 rows of cells, yellowish, in the middle of dorsal lamina 6-12 $\mu \mathrm{m}$ wide, extending to apex or vanishing shortly below; costa percurrent or mostly vanishing immediately below apex; lamina unistratose, cells in upper part of leaf \pm hexagonal or 
rounded hexagonal, ca 7-20 $\mu \mathrm{m}$, in the middle of the dorsal lamina 7-16 (-20) $\mu \mathrm{m}$ long and $4-12 \mu \mathrm{m}$ wide.

Autoicous, paroicous, synoicous or rarely dioicous; archegonia 200-310 $\mu \mathrm{m}$ long, terminal, rarely in axils of cauline leaves immediately below the perichaetium; antheridia 120-200 $\mu \mathrm{m}$ long, in groups of $1-3$, naked (without perigonial leaves, but sometimes with one - MEINUNGER and SCHRÖDER 2007 - or two bracts - Fig. 23M, N, O) in the axils of cauline leaves in the upper and middle part of the stem (small, bud-like androecia also rarely present in axils of lower cauline leaves, terminal synoicous inflorescences also occur rarely). Sporophytes frequent, usually present (in $86 \%$ of specimens seen).

Seta terminal (but sporophytes sometimes appear to originate at the base of shoots, when a younger shoot continues growth laterally - Fig. 23B), yellowish to reddish, to ca $8 \mathrm{~mm}$ long, thin, geniculate at base, capsules \pm erect and symmetric, rarely slightly inclined, $0.4-0.8 \mathrm{~mm}$ long, ellipsoidal, lid conical, obliquely rostellate; peristome teeth at their base $37-53 \mu \mathrm{m}$ wide, filaments papillose with spiral thickenings; spores $c a(9-) 12-20 \mu \mathrm{m}$, finely papillose to nearly smooth, ripening autumn to spring.

This species is characterised by (i) naked antheridia regularly present in leaf axils along the stem, (ii) a rather wide leaf apex with an often asymmetric apiculus, and (iii) a particular habitat on silt-covered tree trunks or dead wood in the inundation area of large rivers.

Note on variability: Observations by the author of many populations of $F$. gymnandrus growing in the Danube inundation area indicate that the occurrence of bracts combined with otherwise naked antheridia is not a constant feature. Even within a given patch plants with naked antheridia (the most frequent character state) are mixed with others, where the antheridia are accompanied by one or two bracts (see Fig. 23M, N, O), and even more rarely, are situated in bud-like perigonia.

The different combinations of naked or perigonial, axillary or terminal antheridia, also mixed with archegonia, are all present in the type collection (BRUgGeman-NANNENGa 1989). However, dwarf male bud-like plants are not known in this taxon.

Similar species:

F. bryoides: leaves less ovate or less elliptical, more parallel-sided or acuminate; antheridia mostly in perigonia, rarely naked; terrestrial, different habitat (F. gymnandrus: leaves ovate to elliptical, only very shortly acuminate to acute or obtuse; antheridia mostly naked, very rarely in bud-like branches; growing mostly on inundated wood or stones near great rivers)

F. viridulus: leaves narrower, $0.15-0.45 \mathrm{~mm}$ wide, (2.5-) 3-6 times as long as wide; antheridia mostly in dwarf male bud-like shoots or plants; terrestrial, not 


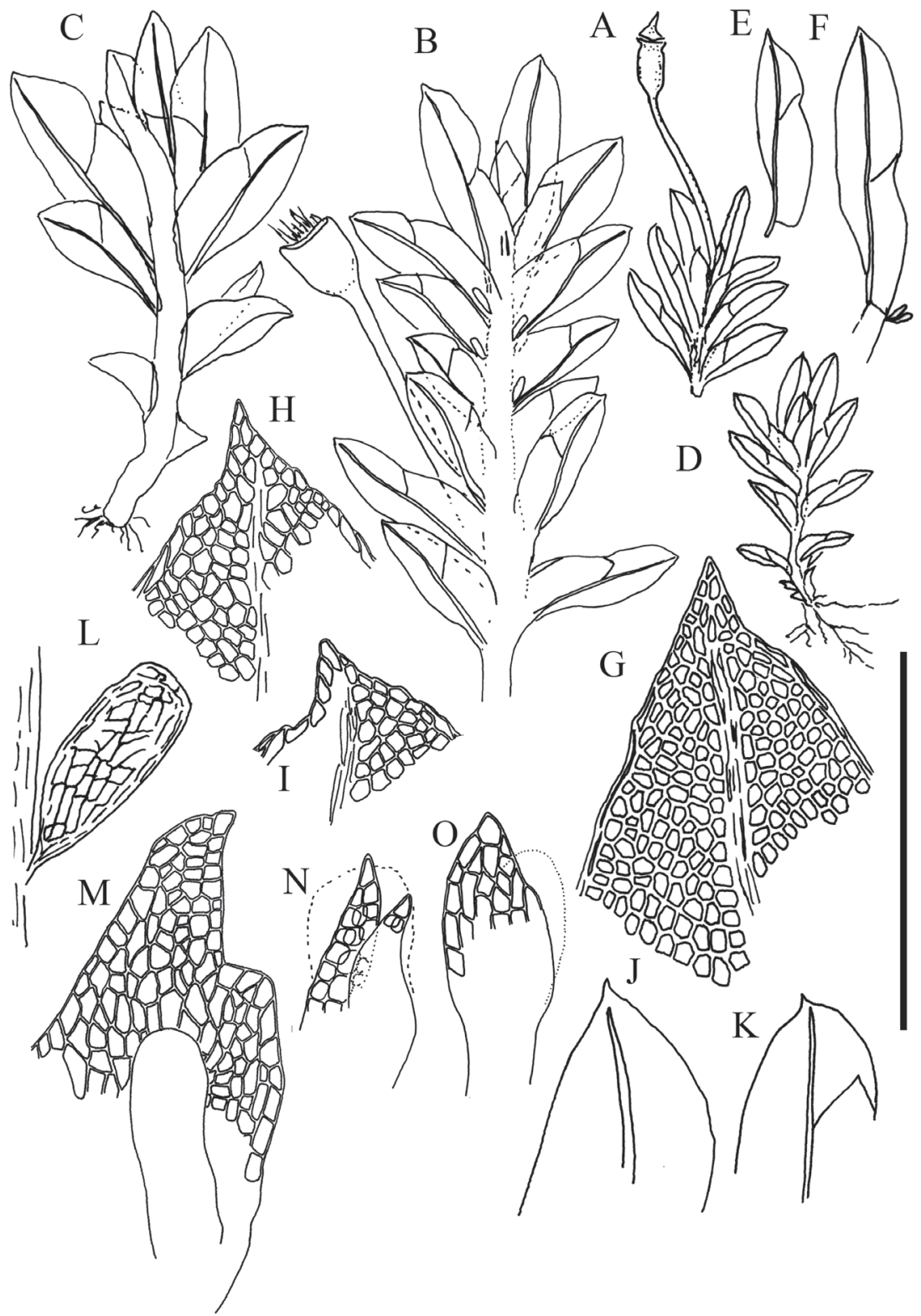

Fig. 23. Fissidens gymnandrus: $\mathrm{A}, \mathrm{B}=$ habit of plants with sporophytes (B sporophyte seemingly basal due to innovation); $\mathrm{C}, \mathrm{D}=$ habit of plants without sporophytes; $\mathrm{E}, \mathrm{F}=$ leaves ( $\mathrm{F}$ with naked antheridia attached); G, H, I, J, K = leaf apices; $\mathrm{L}=$ antheridium; $\mathrm{M}, \mathrm{N}, \mathrm{O}=$ bracts with antheridia. Scale bar: A, D - 4.66 mm; B, C, E, F - 2 mm; G, H, I, L, M, N, O - $200 \mu \mathrm{m}$; J, K - $800 \mu \mathrm{m}$ [A, C, D, E, F, G, L: Erzberger 11296 (Germany, Karlsruhe 2005); B, M, N, O: Erzberger 20288 (Hungary, Kisoroszi 2015); H, I, J, K: Erzberger 21033 (Hungary, Halásztelek 2015)]. 
hydrophilous (F. gymnandrus: leaves wider, 0.3-0.65 mm wide, 2-3 (-4) times as long as wide; antheridia mostly naked in leaf axils, never in dwarf male bud-like plants; hydrophilous plant growing on inundated wood or stones).

F. crassipes: see the note under that species.

References: Limpricht (1890: 430-431), BRUgGEMAN-NANNENGA (1989: 77, 80, 84), Ahrens (2000: 99-101, 115-117), Cortini Pedrotti (2001: 132-133).

Habitat, substrate: Often covered with silt or mud on periodically inundated wood, base of willows and ashes, in other European countries also on inundated, often mud- or silt-covered stones along rivers (riverbank reinforcements); sometimes on ground on decaying herbaceous plants in or beside streams and pools (but see below).

Associated bryophytes: Amblystegium serpens, $A$. varium, Barbula unguiculata, Brachy thecium salebrosum, Bryoerythrophyllum recurvirostrum, Bryum moravicum, B. pseudotriquetrum, Didymodon luridus, Fissidens dubius, F. taxifolius, Homalia trichomanoides, Leptodictyum riparium, Leskea polycarpa, Poblia wablenbergii.

Vertical distribution: $85-310 \mathrm{~m}$ a.s.l.

Distribution in Hungary: (31 specimens, 25 recent grid cells). - Danube inundation area Most of the records known at present and a map showing their distribution were published earlier (ERZBERGER et al. 2015). The map is probably very incomplete; the species should also be searched for in the inundation area of other rivers.

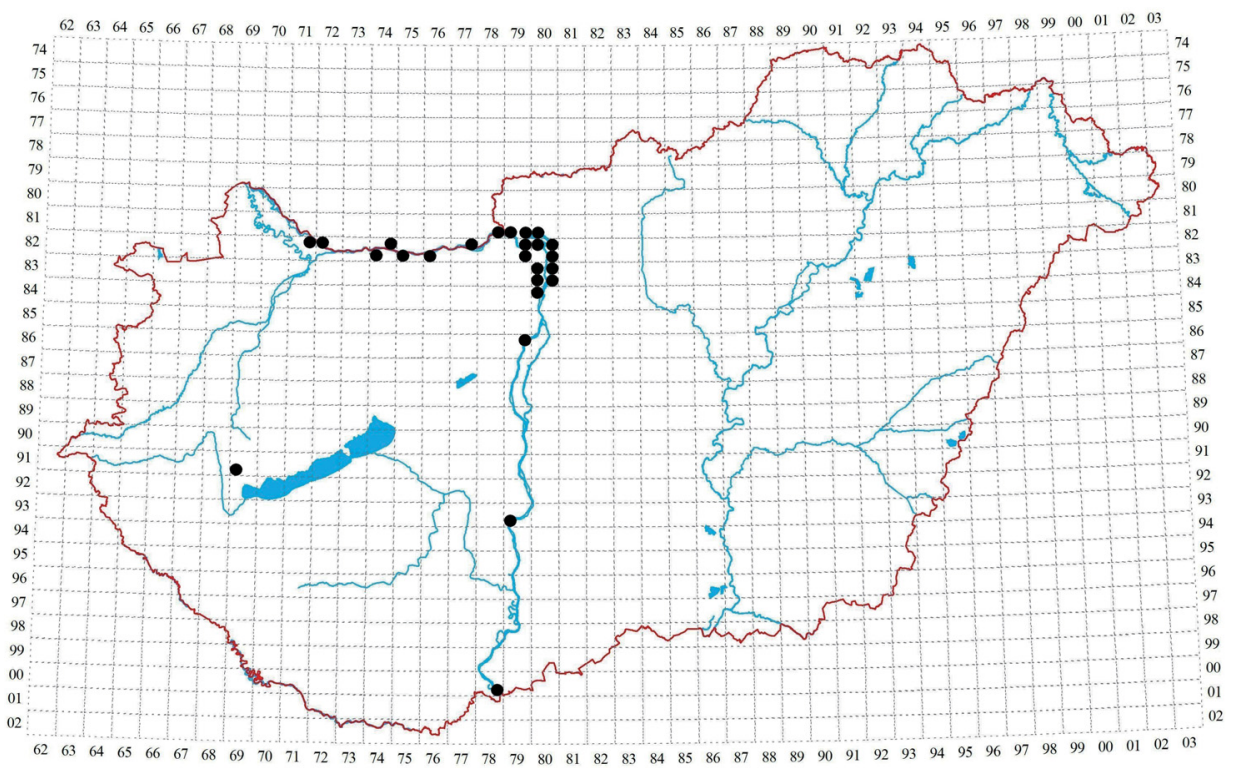

Fig. 24. Records of Fissidens gymnandrus. 
There remains the question whether plants with naked axillary antheridia growing in different habitats away from rivers belong to $F$. gymnandrus or not. I have, with reservations, included plants from non-riverine habitats in the map for F. gymnandrus. This refers to the following collections: Visegrád Mts (8279.4) Kom. Pest, Pilisszentlászló, Tal des Baches Bükkös-patak, nahe der Quelle Kárpát-forrás, auf Andesitblock am Bach, N 47 42’ 25.1”, E 18 58’38.4”, 310 m, 04.06.2014, leg. P. Erzberger and Cs. Németh (B-Erzberger 17943). Gerecse Mts (8276.3) Kom. Komárom-Esztergom, Neszmély, Vár-hegy, Löss-Hohlweg, N $47^{\circ} 43^{\prime} 50.5^{\prime \prime}$, E $18^{\circ} 22^{\prime}$ 03.2”, 200 m, 13.04.2013, leg. P. Erzberger and P. Szücs (B-Erzberger 15923). Keszthely Mts (9169.3) Kom. Zala, Rezi, nahe Csóka-kő, Dolomitgrube, 27.06.2013, leg. Cs. Németh and P. Erzberger (B-Erzberger 16437).

Distribution in adjacent countries: Austria, Slovenia, Croatia, and Ukraine only, but since the taxon is sometimes reduced to a variety of $F$. bryoides, it might be missing from some checklists, and the information may be incomplete. Candidate for the new European red list (HodgetTs 2015).

Literature: ERZBERGER et al. (2015).

Red list status: DD (PAPP et al. 2010), NT is appropriate (ERZBERGER et al. 2015).

Note on taxonomic status: According to Bruggeman-Nannenga in Hill et al. (2006), "F. gymnandrus is treated by North American authors and IgNATOV and Afonina (1992) as a synonym of F. bryoides. However, it differs from $F$. bryoides s. str. in being polyoicous, having oblong leaves with a wide apex, and by its preference for wooden substrates in regularly flooded localities" (Ann. 97).

The author agrees with other Central European bryologists that plants with naked axillary antheridia from riverine habitats represent $F$. gymnandrus. However, in the literature, naked axillary antheridia are occasionally reported also for F. bryoides ("zelden naakt in de bladoksels": BRUGGEMAN-NANNENGA 1989: 80, 81). Several authors (e.g. MEINUNGER and SCHRÖDER 2007: 30, KöCKIngER et al. 2008: 284, Hradilek: pers. comm.) report such plants also from other habitats, but are of different opinion as to their taxonomic status (see above).

Fissidens incurvus Starke ex Röhl.

(= F. viridulus var. incurvus (Starke ex Röhl.) Waldh., F. bryoides subsp. incurvus (Starke ex Röhl) Bertsch, F. haraldii (Lindb.) Limpr., F. sardous De Not., F. tamarindifolius (Turner) Brid.)

(Figs 25, 26)

Plants gregarious or growing in dense or lax turf, mostly pale to vivid green, to ca $1 \mathrm{~cm}$ long, fertile shoots decumbent, female stems $3-5(-6.5) \mathrm{mm}$ long, 
mostly unbranched; leaves in 5-10 (-15) pairs, uppermost leaves of female stems (1.2-) 1.4-1.9 mm long and (0.2-) 0.3-0.5 mm wide, 2.5-6.5 times as long as wide; perichaetial leaves $1.7-2.7 \mathrm{~mm}$ long; leaves lingulate lanceolate, oblong lanceolate, lanceolate or elliptical, suddenly narrowed to a short, mostly acute stout point, sometimes cuspidate, apical lamina \pm as long as sheathing part, dorsal lamina extending to leaf insertion to decurrent; leaf margin \pm entire; limbidium well developed, narrow, pale, 1-2-stratose and consisting of several cell rows, in the middle of the dorsal lamina $7-15 \mu \mathrm{m}$ wide, mostly extending to apex and confluent with costa, not reaching base of dorsal lamina; costa rather thin, percurrent or excurrent as a short mucro in upper leaves; lamina unistratose, laminal cells in upper part of leaf hexagonal to rounded hexagonal, thin-walled,

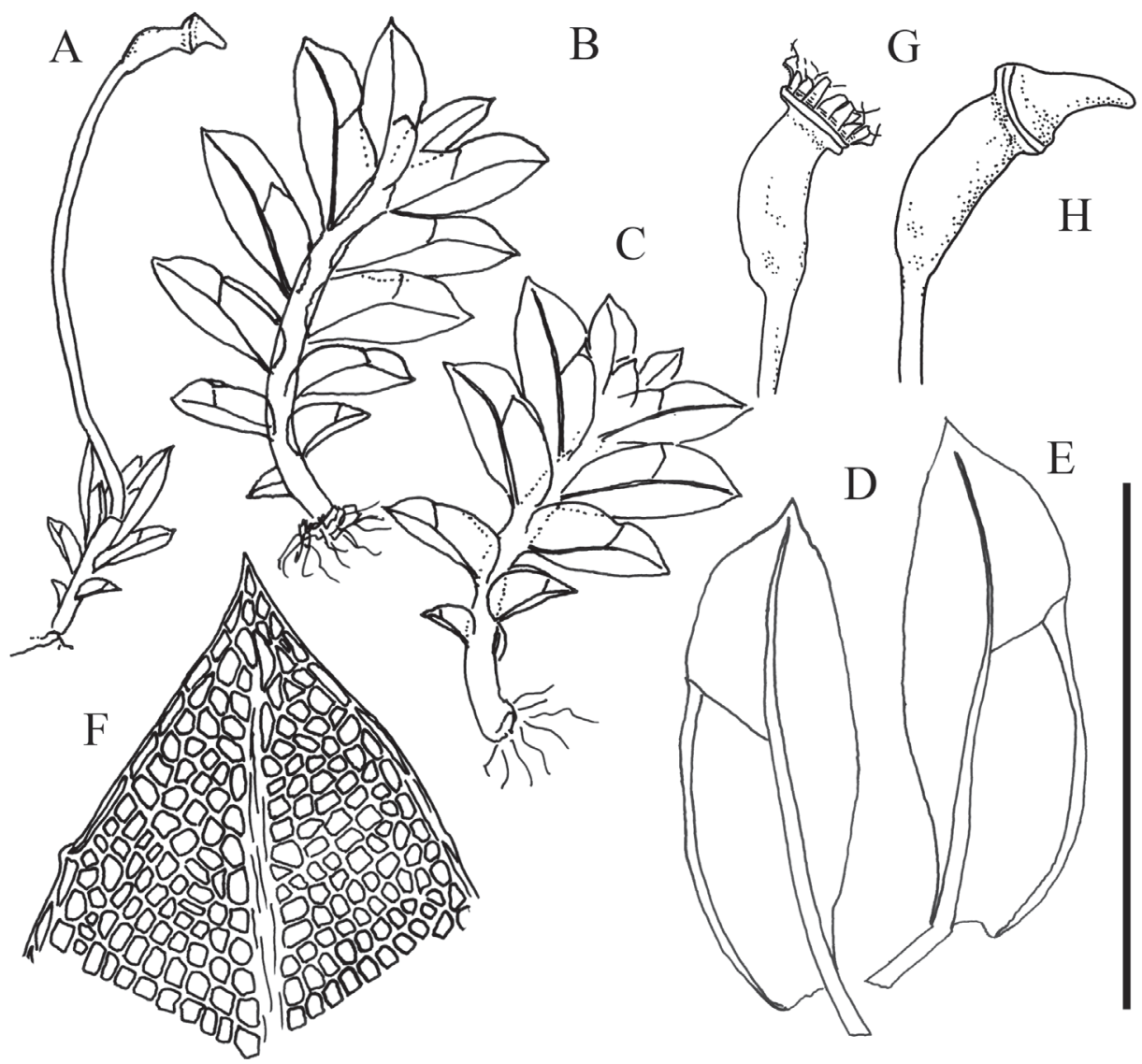

Fig. 25. Fissidens incurvus: $\mathrm{A}=$ habit of plant with sporophyte; $\mathrm{B}, \mathrm{C}=$ habit of plants without sporophytes; D, E = leaves; F = leaf apex; G, H = capsules (dry). Scale bar: A - 4.86 mm; B, C - 2 mm; D, E- $800 \mu \mathrm{m} ; \mathrm{F}-200 \mu \mathrm{m} ; \mathrm{G}, \mathrm{H}-1.6 \mathrm{~mm}$ [Erzberger 6763]. 
ca (6-) 8-12 (-15) $\mu \mathrm{m}$ long (measured in the direction of their greatest extension), in the middle of the dorsal lamina (6-) 9-15 (-17) $\mu \mathrm{m}$ long and (4-) 6-9 $(-11) \mu \mathrm{m}$ wide.

Autoicous or dioicous, archegonia 210-350 $\mu \mathrm{m}$ long, terminal; antheridia 120-220 $\mu \mathrm{m}$ long, terminal in foliate, bud-like, minute or taller shoots, mostly at the base of female shoots, or solitary; very rarely also in bud-like branches in the axils of lower cauline leaves. Sporophytes frequent, regularly present (in 100\% of specimens seen).

Seta terminal, yellowish-reddish, 4-8.5 (-11) mm long, thick, geniculate at base and with a hook-like bend at the tip; capsules inclined to horizontal, asymmetric, ventricose, curved, rarely almost erect, 0.7-1.2 mm long, elongate-ovate to ellipsoidal, narrowed to seta, widened below mouth; lid conical, to $0.4 \mathrm{~mm}$ tall, acuminate; peristome teeth at their base 31-48 $\mu \mathrm{m}$ wide, filaments very thin, papillose, with spiral thickenings; spores $10-15(-18) \mu \mathrm{m}$, brownish, finely papillose, ripening autumn to spring.

This terricolous species is characterised by (i) inclined asymmetric capsules, and (ii) antheridia mostly in dwarf male plants or shoots, not axillary.

Similar species:

F. bryoides: antheridia mostly in minute, bud-like axillary branches, never in dwarf plants; capsules erect ( $F$. incurvus: antheridia in dwarf male plants; capsules curved, inclined).

F. viridulus: see the note under that species.

References: Limpricht (1890: 422-426, 431-434), Demaret and CASTAGNe (1959: 52-53, 64-65), NyHolm (1987: 8, 11), BRUgGEMAN-NANNENGA (1989: 77, 81-82), Ahrens (2000: 99-101, 115-117), Cortini Pedrotti (2001: 129-130), Smith (2004: 240-242, 247), Guerra and Ederra (2015: 170-172).

Habitat and substrate: On clay and calcareous soil in shaded, sometimes moist places, mostly in forests or at the forest edge (rarely on soil in fissures of andesitic or basaltic rocks).

Associated bryophytes: Bryum argenteum, B. rubens, B. ruderale, Campylium calcareum, Ceratodon purpureus, Didymodon insulanus, Fissidens exilis, F. taxifolius, Homalothecium lutescens, Pleuridium subulatum, Pottia intermedia, Weissia longifolia.

Vertical distribution: $85-500 \mathrm{~m}$ a.s.1.

Distribution in Hungary: (26 specimens, 21 grid cells, of which 10 represent recent finds). - Bükk Mts (7988.4) Heves County, Felsőtárkány, Lök-völgy, abandoned schist quarry, N 48 01' 43.8”, E 20²8'47.7”, 455 m, 06.08.2015, leg. Cs. Németh and P. Erzberger (B-Erzberger 20379). Mátra Mts (8084.4) Nógrád County, Pásztó-Mátrakeresztes, Erdész-rét west of the village, andesite grass- 
land with rock outcrops, N $47^{\circ} 54^{\prime} 16.5^{\prime \prime}, \mathrm{E} 19^{\circ} 47^{\prime} 59.2^{\prime \prime}, 470 \mathrm{~m}, 07.10 .2015$, leg. P. Erzberger and P. Szűcs (B-Erzberger 20729). Börzsöny Mts (8179.3) Comit. Hont. In argillosis silv. vallis Bőszobi-patak prope Szob, 160 m, 31.10.1954, leg. Á. Boros sub Fissidens bryoides BP 94131. Naszály (8180.4) Pest County, close to border of Nógrád County, Szendehely-Katalinpuszta, Gyadai-meadow, on an ant hill, N 47 50'58”, E 19 07’ 22”, 210 m, 09.04.2007, leg. P. Erzberger and P. Szücs (B-Erzberger 12170). Vértes Mts (8576.3) Comit. Fejér. In argillosis silvaticis Haraszt-erdő inter Vérteskozma et Vértesboglár, $250 \mathrm{~m}, 25.03 .1935$, leg. Á. Boros sub Fissidens bryoides BP 94104. Bakony Mts (8772.2) Comit. Veszprém. In argillosis arenosis piceet. cult. supra Szépalma-puszta prope Borzavár, 500 m, 03.10.1937, leg. Á. Boros sub Fissidens bryoides BP 94094. Balaton uplands (9071.4) Veszprém County, Balatonhenye, Fekete-hill, near the pond Monostoritó, Vaskapu-árok stream bed, soil over basaltic bedrock, N $46^{\circ} 54$ ' 31.2”, E $17^{\circ}$ 35’ 56.8”, 350 m, 30.09.2014, leg. P. Erzberger and Cs. Németh (B-Erzberger 18990). Keszthely Mts (9169.4) County Veszprém. Keszthelyi Mts. On soil near Vadvízárok in SW and NW direction, in forest at Vállus, $300 \mathrm{~m}, 18.10 .1999$, leg. et det. B. Papp BP 166727. Zala (9167.3) Zalaegerszeg, Janka tető alatti út oldalában, 16.11.1940, leg. A. Visnya det. Á. Boros as Fissidens bryoides BP 94776. Inner Somogy (9271.3) Comit. Somogy. In sylvestribus montis Fonyódi hegy prope pag. Fonyód, 08.07.1964, leg. L. Vajda sub Fissidens bryoides BP 69453. Zselic (9874.3) Baranya County, Bükkösd, near the road between Bükkösd and

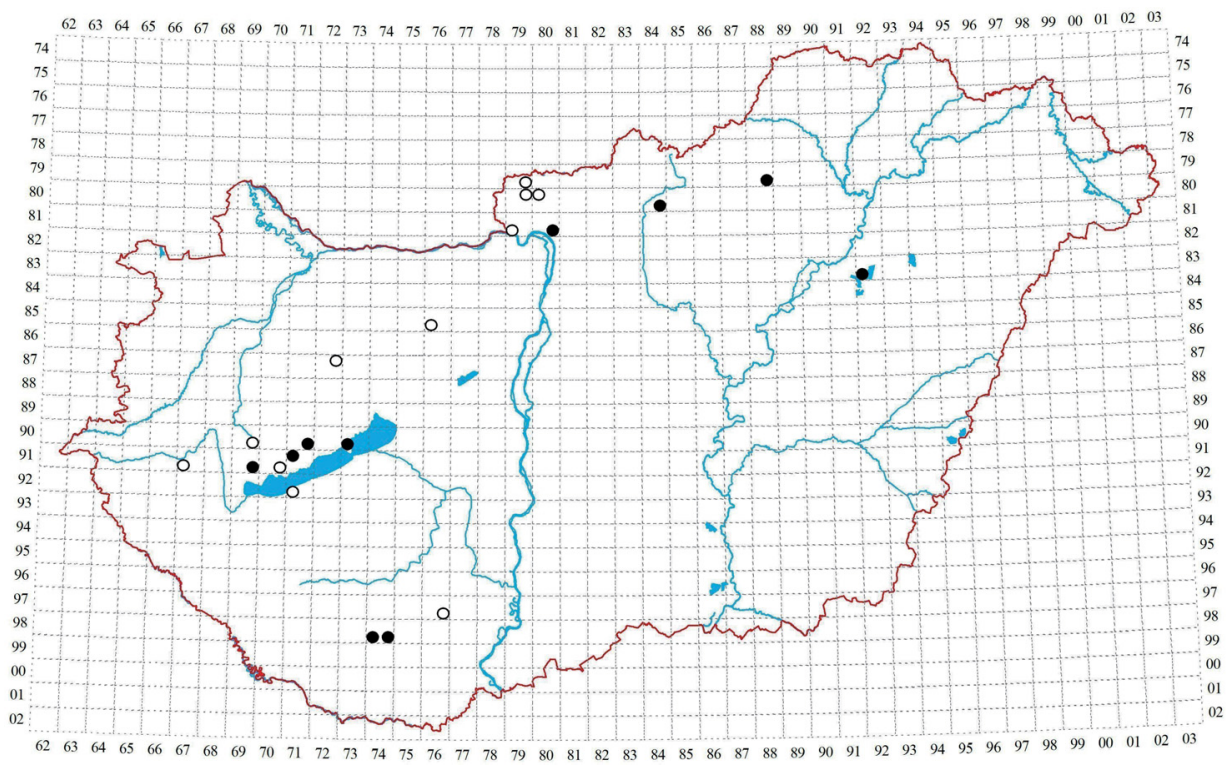

Fig. 26. Records of Fissidens incurvus. 
Hetvehely, spruce plantation, N 4607' 38.4”, E 1801'51.4”, 160 m, 14.10.2015, leg. P. Erzberger, J. Deme and D. Kovács (B-Erzberger 20824). Mecsek Mts (9776.4) Hungaria merid. Comit. Baranya. In sylvestribus prope pag. Mecseknádasd, 25.02.1965, leg. L. Vajda 25.02.1965 sub Fissidens bryoides BP 70802. Tiszántúl (8392.3) Hajdú-Bihar County, at Hortobágyi halastó lake near Hortobágy vil-

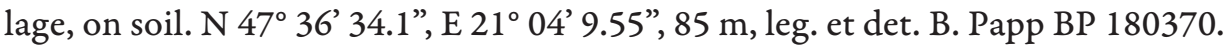

The map (Fig. 26) is still very incomplete and does not show any geographical trend.

Distribution in adjacent countries: In all countries surrounding Hungary except Croatia; red-listed in Austria (3, corresponds to EN), DD in Slovenia and Slovakia (HodgetTs 2015).

Literature: Boros (1968) reported this species (as var. of F. bryoides, but with the note "vielleicht eine selbständige Art" (perhaps an independent species) for the Buda Mts and Köszeg Mts, but no vouchers were found in this revision to support this. The same area is also given for " $F$. bryoides $\mathrm{f}$. tamarindifolius" in Boros (1968), and for "F. bryoides ssp. incurvus" in ORBÁN and VAJDA (1983).

Red list status: EN according to PAPP et al. (2010); NT seems appropriate.

Note on taxonomic status: According to Bruggeman-Nannenga in Hill et al. (2006), F. incurvus is reduced to varietal rank, because " $F$. viridulus var. incurvus is linked to var. viridulus by transitional forms. North American authors treat both taxa as expressions of F. bryoides" (Ann. 102). According to SMITH (2004: $247)$ "plants with the gametophyte of $F$. incurvus and erect capsules similar to those of F. viridulus confuse the distinctions between the two species. However, it is likely that such plants are erect-capsuled forms of $F$. incurvus rather than intermediates."

Most authors include F. tamarindifolius (Turner) Brid. (= F. incurvus var. tamarindifolius (Turner) Braithw.), which differs from the typical variety by leaves only twice as long as wide and apical lamina shorter than vaginant laminae.

Since $F$. incurvus can only be identified in the presence of capsules, populations without capsules would probably be taken for the similar F. viridulus. Some records of " $F$. viridulus" based on sterile specimens might therefore include $F$. incurvus.

\section{Fissidens kosaninii Latzel \\ (=F. valiae P. de la Varde)}

Plants growing in dense, olive-green turf, partly incrusted, plants 3-5 $\mathrm{mm}$ long (5-7 mm including sporophyte), decumbent to ascending, with 12-15 pairs of leaves; lower leaves numerous, scale-like, upper leaves (subperichaetial and perichaetial leaves) suddenly much elongate, cultriform, narrowly linear-lanceo- 
late, shortly acuminate, tapering to an acute apex, $1.26 \mathrm{~mm}$ long and 0.18-0.25 $\mathrm{mm}$ wide, the uppermost leaves connivent; apical lamina shorter than sheathing part, dorsal lamina narrow, mostly reaching insertion in one cell row, rarely ceasing above insertion; all leaves lacking limbidium completely or limbidium restricted to sheathing part; laminal cells irregularly hexagonal, $10-11 \mu \mathrm{m}$ in diameter.

Synoicous, rarely polyoicous.

Seta 2-3 mm long, flexuose, geniculate above vaginula; capsule symmetric, erect, elliptic, constricted below mouth after the lid has fallen; lid short, obliquely rostrate; spores $10-13(-15) \mu \mathrm{m}$.

Habitat, substrate: On calcareous tufa near waterfall, associated with Hydrogonium ehrenbergii, Eucladium verticillatum, Fissidens crassipes, Gymnostomum calcareum, Rhynchostegiella curviseta, Platybypnidium riparioides, Cratoneuron filicinum and others.

Reference: LATZEL (1931). The above description is taken from the protologue. Bizot and Pierrot (1964), in an amended description of $F$. valiae, stated that the limbidium is confined to vaginant laminae, and the leaf cells are minutely papillose. CoRLEY (1980: 197) characterised F. kosaninii in the following way: "up to 15 pairs of narrow (to 6 times as long as wide) leaves; plant on dry limestone rocks." This habitat is fundamentally different from the one given by LATZEL (1931). The description in Frahm in FREY et al. (2006): "Leaf border on all leaves. Plants $2-5 \mathrm{~mm}$ long with up to 15 pairs of leaves. On shady calcareous boulders. Only in the Mediterranean. (F. valiae P. de la Varde)" is in obvious contradiction to the original description by LATZEL (1931).

Distribution in Hungary: Provisionally excluded (see below).

Distribution in adjacent countries: Information incomplete, F. kosaninii is missing in Hodgetts (2015), according to SABovlJEvić et al. (2008) occurring only in Croatia among the countries surrounding Hungary; listed in the Red data book of European bryophytes (ECCB 1995) in the K (unsufficiently known) category, endemic to Europe.

Literature: VAJDA (1958) reports F. kosaninii from the streams Dósnyapatak and Kemence-patak in Börzsöny Mts, based on his own collections and a determination by Potier de la Varde. Later, VAJDA (1975) changed his opinion, convinced by Z. Pilous who revised the specimens in question to $F$. exiguus and provided original material of $F$. kosaninii for comparison. This opinion was also confirmed by M. Bizot.

Unfortunately, I was not able to study original material of F. kosaninii, and therefore I cannot examine the value of this taxon and evaluate the opinions of Vajda, Pilous and Bizot. The material from Dósnya-patak (BP 94658) is provisionally identified as F. exiguus, although it differs in some respects (e.g. longer 
and narrower perichaetial leaves, up to $>10$ times as long as wide; limbidium rudimentary even on vaginant laminae of perichaetial leaves) from the material of that species seen.

Note on taxonomic status: F. kosaninii is omitted in Bruggeman-Nannenga in Hill et al. (2006: Ann. 92) (together with F. exiguus) as "poorly limbate form of limbate species", omitted in Hodgetts (2015).

\section{Fissidens osmundoides Hedw.}

(Fig. 27)

Plants growing mostly in \pm dense to lax turf or gregarious, often matted together by brown rhizoids, erect, vivid green, light green or dark green, ca 1-3 $(-10) \mathrm{cm}$ long, with basal innovations; rhizoids sometimes ascending the stem a short distance, slightly papillose to smooth; leaves in numerous (10-25) pairs, to $c a 2 \mathrm{~mm}$ long and ca $0.5(-0.7) \mathrm{mm}$ wide, lingulate lanceolate, oblong lanceolate, broadly lingulate or ovate lingulate, abruptly narrowed to a short, obtuse to \pm acute apex; apical lamina shorter than or as long as sheathing part, dorsal lamina extending to leaf insertion or sometimes slightly above, rounded at base, not decurrent; elimbate, margin evenly and finely serrulate or crenulate by pro-

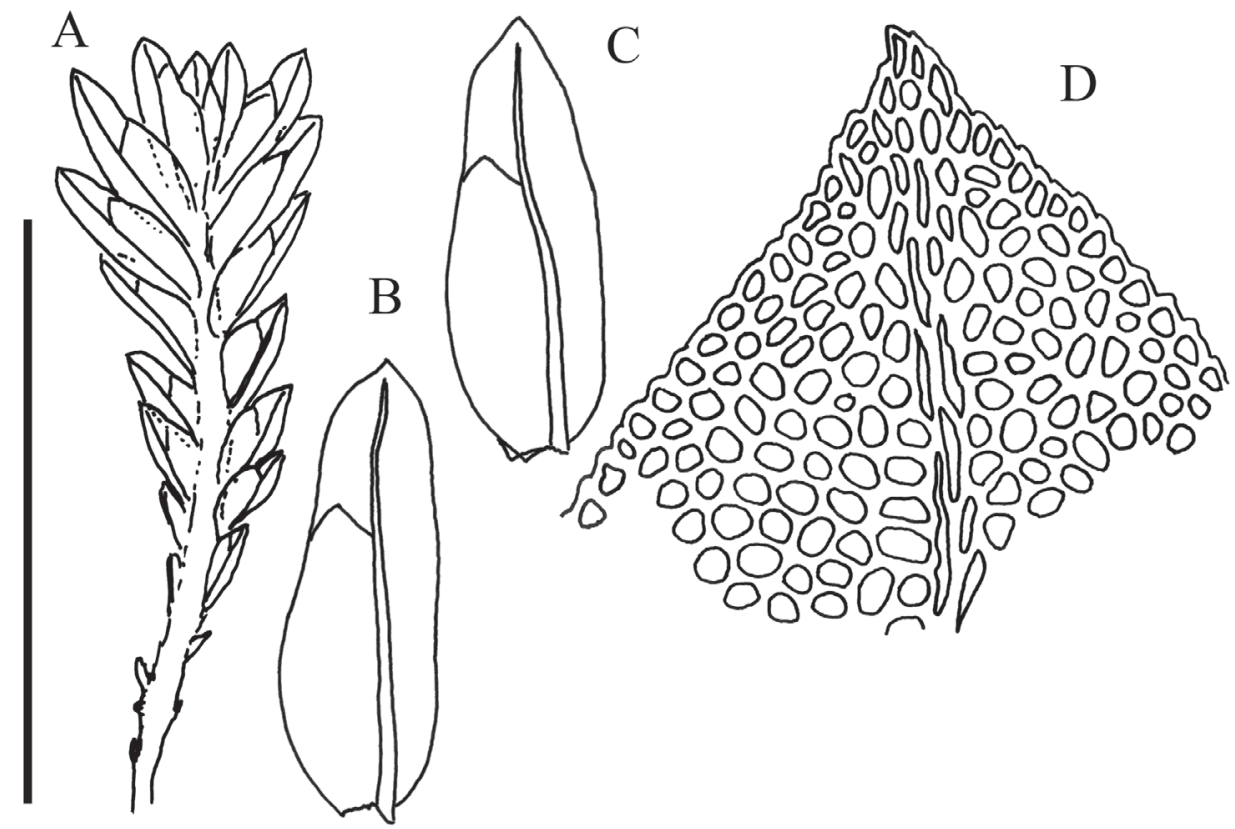

Fig. 27. Fissidens osmundoides: $\mathrm{A}=$ habit; $\mathrm{B}, \mathrm{C}=$ leaves; $\mathrm{D}=$ leaf apex. Scale bar: $\mathrm{A}-4.6 \mathrm{~mm}$; $\mathrm{B}, \mathrm{C}=2 \mathrm{~mm} ; \mathrm{D}=200 \mu \mathrm{m}$ [Erzberger 7591 (Austria, Riesachsee 2001)]. 
truding cell ends, particularly in upper part of leaf, marginal cell row somewhat lighter than inner cells; costa mostly ending distinctly below leaf apex, 35-50 $\mu \mathrm{m}$ wide at mid leaf; lamina unistratose, laminal cells in upper part of leaf irregularly hexagonal to rounded hexagonal, \pm incrassate, \pm opaque, ca 10-20 $\mu \mathrm{m}$ long (measured in the direction of their greatest extension), 12-22 $\mu \mathrm{m}$ wide in the middle of apical lamina, in the middle of dorsal lamina ca 10-16 $\mu \mathrm{m}$, slightly smaller towards margin, often much differing in size, not or only slightly bulging.

Light to dark brown or blackish irregularly-shaped rhizoidal tubers, to 1.5 $\mathrm{mm}$ long.

Dioicous. Archegonia and antheridia terminal. Sporophytes occasional to infrequent.

Seta terminal, yellow or purple to reddish, 3-7 (-14) mm long, erect or flexuose, capsules erect to slightly inclined, mostly symmetric to slightly curved, ca $1.5(-1.8) \mathrm{mm}$ long, ellipsoid to elongate ovate, wide-mouthed when lid has fallen off; lid conical, longly rostrate; calyptra mitrate; peristome teeth to $85 \mu \mathrm{m}$ wide at base, lower portion of filaments papillose-striate vertically, upper portion vertically striate, without spiral thickenings; spores $13-20(-25) \mu \mathrm{m}$, finely papillose to nearly smooth.

This medium-sized to robust species is characterised by (i) leaves lacking limbidium on all laminae, (ii) crenulate leaf margin, (iii) costa not reaching \pm blunt apex, and, if present, (iv) terminal seta. The laminal cells are usually wider than in other species with unbordered leaves.

Of the species treated here this is the only one with papillose rhizoids (Pursell and Bruggeman-Nannenga 2004), best seen on mature, dark brown rhizoids of 10-20 $\mu \mathrm{m}$ diameter; thicker rhizoids appear \pm smooth, perhaps papillae disappear with age.

Similar species:

F. taxifolius: see the note under that species.

F. adianthoides: plants usually larger; leaves irregularly coarsely dentate near apex, at least in uppermost leaves; mostly with a pale border or several rows of incrassate cells; gametangia axillary ( $F$. osmundoides: plants smaller; leaves not coarsely dentate, finely and evenly serrulate or crenulate throughout, not just below; pale border of incrassate marginal cells in a single row; gametangia terminal).

References: Limpricht (1890: 448-449), Demaret and CASTAgne (1959: 52-53, 76-77), Nyholm (1987: 8, 12-13), Bruggeman-NANnenga (1989: 77, 85-87), Ahrens (2000: 99-101, 119-120), Cortini Pedrotti (2001: 136137), Smith (2004: 240-243, 253, 255), GuerRA and EderRA (2015: 184-186).

Habitat and substrate: In moist meadows, on peat, on moist to wet humusrich soil, in rock crevices, often on decaying wood, sometimes on rocks by streams.

Distribution in Hungary: Excluded. 
Distribution in adjacent countries: Reported from all countries surrounding Hungary except Serbia; red-listed in Romania (VU) and Slovakia (NT) (HodgetTs 2015).

Literature: ORBÁN and VAJDA (1983) erroneously reported the species from Hungary based on a collection by I. Galambos, but the specimen was later revised by B. Papp to Fissidens taxifolius (ERzBERGER and PAPP 2004). F. osmundoides is therefore excluded from the bryoflora of Hungary.

$$
\begin{aligned}
& \text { Fissidens ovatifolius R. Ruthe } \\
& \text { (=F. obductus (Vent.) Giacom.) }
\end{aligned}
$$

Plants (3-) 5-10 (-17) mm long, densely foliated with (4-) 6-15 (-19) pairs of leaves, simple or branched, sterile plants taller than fruiting plants; leaves $1-1.8$ $\mathrm{mm}$ long and $0.4-0.7 \mathrm{~mm}$ wide, $2-3(-4.5)$ times as long as wide, broadly elliptical to oblong, rarely obovate, apex varying from obtuse in very wide leaves to acute in less wide ones, often with a short acuminate apiculus; perichaetial leaves relatively long and narrow, often with an acute apex, 1.4-2.4 mm long; apical lamina \pm as long as sheathing part or shorter; dorsal lamina ending far above the insertion (or in its lower part reduced to a narrow band of limbidium cells); margin slightly denticulate at apex; limbidium present on all laminae, strong, unistratose, yellowish, consisting of (2-) 3-4 (-5) rows of cells, 5-6 $\mu \mathrm{m}$ wide in dorsal lamina, (12-) 16-20 (-24) $\mu \mathrm{m}$ wide in sheathing part, almost reaching apex, confluent with costa or not, intralaminar in mature leaves; costa almost reaching apex, 25-30 $\mu \mathrm{m}$ wide at mid leaf; lamina unistratose, occasionally pluristratose alongside costa, rarely apex pluristratose, laminal cells very small, 4.5-7.5 (-15) $\mu \mathrm{m}$ long and 3-6 $(-10) \mu \mathrm{m}$ wide, often mamillose on both surfaces, opaque.

Autoicous or dioicous; archegonia 280-400 $\mu \mathrm{m}$ long, terminal; antheridia $160-210 \mu \mathrm{m}$ long, either terminal on dwarf or taller male plants, or axillary in buds in the lowermost leaves.

Seta red, 2-3 (-7) mm long, thin; capsule 0.6-1.2 $\mathrm{mm}$ long, erect to slightly inclined, not curved but slightly ventricose, not contracted below mouth; peristome teeth $34.5-45 \mu \mathrm{m}$ wide at base; spores (10-) 12-14 (-20) $\mu \mathrm{m}$.

This small species is characterised by (i) broadly elliptical leaves with a short dorsal lamina that ends far above leaf insertion, (ii) very small laminal cells.

Similar species:

F. crispus: see the note under that species.

References: LIMPRICHT (1904: 677-678), BRUGGEMAN-NANNENGA (1985), Casas et al. (2001: 90-91), Cortini Pedrotti (2001: 132-134), Guerra and EDERRA (2015: 162-164).

Habitat and substrate: On calcareous soil and in rock crevices, lowland. 
Distribution in Hungary: Not recorded.

Distribution in adjacent countries: Reported only from Croatia (HoDGETTS 2015); listed in the Red data book of European bryophytes (ECCB 1995) in the R (rare) category; candidate for the new European red list (HodGETTs 2015).

Fissidens pusillus (Wilson) Milde

(三F. viridulus var. pusillus Wilson)

(Figs 28, 29)

Plants growing in groups or mostly in small, lax turf, green; very small, (1-) 2-7 (-8) mm long, mostly unbranched; leaves in 3-4 (-10) pairs, uppermost leaves much larger than lower cauline leaves, 1-2 mm long and (0.1-) 0.2-0.4 $(-0.5) \mathrm{mm}$ wide, oblong lanceolate to lingulate lanceolate, rather broad, suddenly narrowed to a short and wide, somewhat obtuse or \pm acute apex, margins at apex straight or convex, perichaetial leaves (3-) 4-6 (-7) times as long as wide; apical lamina about as long as sheathing part or longer; dorsal lamina extending to leaf insertion and decurrent along stem; margin entire or weakly denticulate above, limbidium narrow, unistratose, ending below leaf apex, at the middle of dorsal lamina (7-) 9-10 (-17) $\mu \mathrm{m}$ wide, consisting of 1-2 rows of cells, in sheathing part 20-30 $\mu \mathrm{m}$ wide, consisting of 3-5 rows of cells, in lower leaves border often incomplete; costa 15-20 (-25) $\mu \mathrm{m}$ wide at mid leaf, vanishing shortly below leaf apex; lamina unistratose, laminal cells in upper part of leaf irregularly hexagonal, ca (6-) $14(-16) \mu \mathrm{m}$ long and ca $9 \mu \mathrm{m}$ wide, in the middle of dorsal lamina (6-) 7-15 (-18) $\mu \mathrm{m}$ long.

Autoicous, dioicous or synoicous; male plants or shoots small, bud-like or taller, at the base of female plants or solitary; archegonia (250-) 290-350 (-440) $\mu \mathrm{m}$ long, terminal; antheridia ca $200 \mu \mathrm{m}$ long, terminal. Sporophytes regularly present and abundant (in $77 \%$ of specimens seen).

Seta terminal, yellowish to reddish, thin, only a few (to ca $5 \mathrm{~mm}$ ) millimetres long; capsule erect to weakly inclined, \pm symmetric, ovate to elongate-ovate, urn $0.45-0.75 \mathrm{~mm}$ long; lid conical, rostrate, $c$ a $0.32 \mathrm{~mm}$ tall; peristome teeth at their base (24-) 30-47 (-53) $\mu \mathrm{m}$ wide, filaments coarsely papillose, with spiral thickenings; spores (9-) 10-18 (-23) $\mu \mathrm{m}$, nearly smooth to finely papillose.

This hydrophilous species is characterised by (i) the small size of plants, usually $<5 \mathrm{~mm}$ high, (ii) limbate leaves, the limbidium ending well below the leaf apex, (iii) perichaetial leaves to 6 times as long as wide, and (iv) growing firmly attached to usually siliceous rocks in or near streams with clear water.

Similar species:

F. crispus: dry leaves usually crispate; laminal cells very small, 6-8 $\mu \mathrm{m}$, strongly bulging on both faces and about twice as high as wide in cross section $(F$. 
pusillus: dry leaves not crispate; laminal cells larger, 7-15 $\mu \mathrm{m}$, flat, not bulging, about as high as wide in cross section).

F. crassipes, F. exiguus, F. gracilifolius, F. rufulus, F. viridulus: see notes under these species.

References: Demaret and Castagne (1959: 52, 56-58), BruggemanNANNENGa (1982), Nyholm (1987: 8-10), BRuggeman-NANNENGa (1989: 78), Ahrens (2000: 99-101, 120-121), Cortini Pedrotti (2001: 129-131), Guerra and Ederra (2015: 158-159).

Habitat and substrate: Siliceous, rarely basic rocks or boulders, or on wood, in humid shaded sites or in streams.

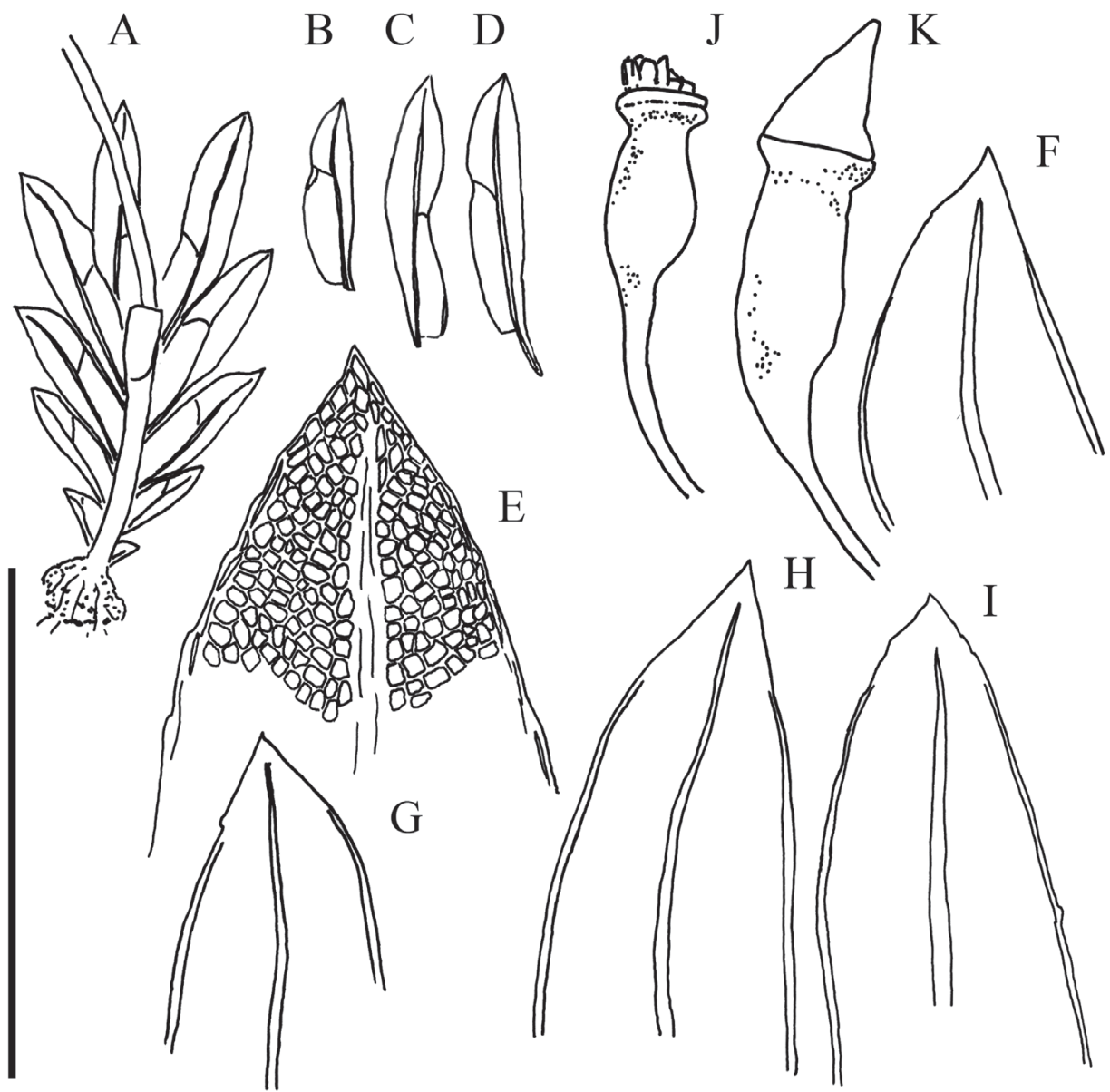

Fig. 28. Fissidens pusillus: $A=$ habit of plant with seta; $B, C, D=$ leaves; E, F, G, H, I = leaf apices (E, H, I of perichaetial leaves; F, G of subperichaetial leaves); J, K = capsules (dry). Scale bar: A, B, C, D - $2 \mathrm{~mm}$; E - $200 \mu \mathrm{m} ; \mathrm{F}, \mathrm{G}, \mathrm{H}, \mathrm{I}-800 \mu \mathrm{m} ; \mathrm{J}, \mathrm{K}-1 \mathrm{~mm}$ [Erzberger 1049]. 
Associated bryophytes: Amblystegium serpens, A. tenax, Anomodon attenuatus, Brachythecium populeum, B. salebrosum, B. velutinum, Bryum capillare, $B$. moravicum, Chiloscyphus polyanthos, Dichodontium pellucidum, Didymodon fallax, D. insulanus, D. luridus, D. vinealis, Eurhynchium crassinervium, Hypnum cupressiforme, Isothecium alopecuroides, Lophocolea heterophylla, L. minor, Metzgeria furcata, Mnium marginatum, M. stellare, Plagiochila porelloides, Plagiothecium cavifolium P. succulentum, Pogonatum sp., Pohlia cruda, Pseudocrossidium revolutum, Pterigynandrum filiforme, Rhizomnium punctatum, Rhynchostegiella teneriffae, Seligeria pusilla, Tetraphis pellucida, Thamnobryum alopecurum, Tortella tortuosa, Tortula subulata.

Vertical distribution: $100-850 \mathrm{~m}$ a.s.l.

Distribution in Hungary: (162 specimens, in addition 42 field data, 44 grid cells, of which 36 represent recent finds). - Zemplén Mts (7594.3) Comit. Abaúj-Torna. In rupibus andesiticis umbrosis-humidis vallis Vajdavölgy prope pag. Pálháza, 01.08.1953, leg. L. Vajda BP 27268. Uppony Mts (7788.1) Kom. Borsod-Abaúj-Zemplén, Upponyi-hg., zwischen Bánhorváti und Sajómercse,

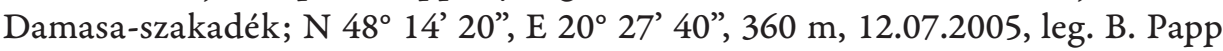
and P. Erzberger (B-Erzberger 11146), dupl. BP 173071 (Borsod-Abaúj-Zemplén County, Uppony Mts, Damassa ravine in the valley of Sompatak stream at Bánhorváti, sandstone rocks, leg. B. Papp). Bükk Mts (7988.2) Kom. BorsodAbaúj-Zemplén, Nagyvisnyó, Ablakos-kő-völgy, Bachbett, Porphyrit, 18.08.1998, leg. P. Erzberger (B-Erzberger 4812). Mátra Mts (8086.3) Heves County, Mátra Mts, Köszörü-patak valley at Hársas-tetö hill at Parád, andesite rocks in the stream, 350 m, 26.07.2000, leg. et det. B. Papp BP 175292, dupl. leg. B. Papp and P. Erzberger (B-Erzberger 6223). Ózdi dombvidék (7987.1) Comit. Heves. In valle supra pag. Tarnalelesz. Ózdi-dombvidék, 21.06.1974, leg. S. Orbán sub Fissidens minutulus BP 154658. Gödöllö Hills (8281.3) Comit. Pest. In arboreto Vácrátót, 130 m, 30.08.1950, leg. Á. Boros BP 94478. Börzsöny Mts (8079.4) Nógrád County, Királyrét at Szokolya, Nagyvasfazék-patak valley, rocks in the stream N 47 54' 11.4', E $18^{\circ} 57^{\prime} 24.1$ ', 320 m, 15.03.2007, leg. et det. B. Papp BP 174727. Visegrád Mts (8179.3) Komárom-Esztergom County, Visegrádi Mts, southern branch of Basaharci valley at Pilismarót, on andesite rocks near the stream N 47 48' 11.2", E 18 50'07.6”', 135 m, leg. et det. B. Papp BP 176599. Pilis Mts (8379.2) Kom. Pest, Csobánka, Szentkút, feuchte Sandsteinmauer, N 47 39' 16.3", E $18^{\circ} 56^{\prime} 45.4$ ", $240 \mathrm{~m}, 04.07 .2012$, leg. P. Erzberger and J. Kis (B-Erzberger 15452). Köszeg Mts (8664.4) Vas County, Bozsok, on siliceous stones in the stream Bozsoki-patak, N 47 20’ 13.4', E $16^{\circ} 28^{\prime} 32.9^{\prime \prime}, 430$ m, 05.11.2015, leg. P. Erzberger, K. Baráth and A. Kausits (B-Erzberger 21089). Mecsek Mts (9776.4) Baranya County, between Óbánya and Mecseknádasd, west side of Templomhill (Sz.-Imre-hegy), Fagetum nudum on steep slope with siliceous, but base-rich 
scree, on soft surface of stone, $\mathrm{N} 46^{\circ} 13^{\prime} 08.2^{\prime \prime}, \mathrm{E} 18^{\circ} 25^{\prime} 56.5^{\prime \prime}, 310 \mathrm{~m}, 29.03 .2015$, leg. P. Erzberger, J. Deme, J. Csiky, det. P. Erzberger (B-Erzberger 19679).

Note: There are some collections from limestone that key out as F. pusillus. I do not believe that they belong to that species. They differ from the typical plants from siliceous rocks by often greater size, so that they might as well be considered weak $F$. crassipes. An in-depth biosystematic study of $F$. pusillus s. 1 . might reveal that this name covers several taxa. I list here - with reservations under F. pusillus - the collections from limestone (these records are not shown on the map for F. pusillus): Aggtelek Karst (7589.1) Comit. Abaúj-Torna et Gömör. In calcareis tophaceis irrigatis fontis Babot-kút vallis Kecsői-völgy prope Jósvafö, 250 m, 10.10.1952, leg. Á. Boros sub Fissidens pusillus BP 94656. (7589.1) Comit. Borsod-Abaúj-Zemplén. In rupibus calc. ad rivum Kecső-patak prope pag. Jósvafö, 260 m, 06.08.1994, leg. B. Papp sub Fissidens pusillus BP 166218. (7589.2) Comit. Abaúj-Torna. In muris irrigatis calcareis tophaceis molae ad Szinpetri, 180 m, 17.06.1953, leg. Á. Boros sub Fissidens pusillus BP 94657. (7589.2) Comit. Borsod-Abaúj-Zemplén in rupibus calcareis irrigatis vallis Bolyamér [prope] pag. Szinpetri, 200 m, 06.08.1994, leg. B. Papp (as admixture to Fissidens taxifolius “in soc cum F. pusillus") BP 164399. Bükk Mts (7889.4) Comit. Borsod. In solo calcareo ad margines rivi Szinvapatak prope pag. Hámor, montes Bükk, 03.09.1962, leg. et det. L. Vajda as Fissidens minutulus c.fr. var. tenuifolius BP 67948. (7889.4) Comit. Borsod. In rupibus calcareis umbrosis humidis cavernae Forrásbarlang,

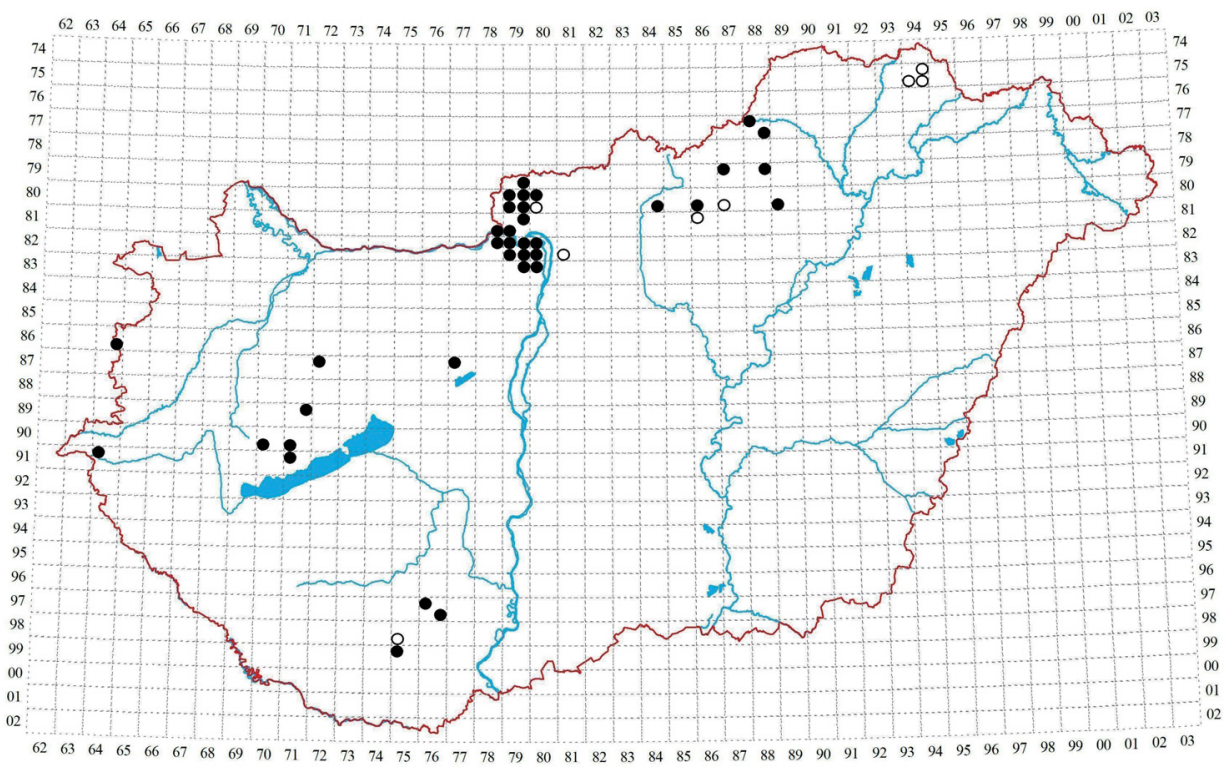

Fig. 29. Records of Fissidens pusillus. 
prope Lillafüred, montes Bükk, 15.10.1969, leg. et det. L. Vajda as Fissidens minutulus BP 74615. Vértes Mts (8475.4) Comit. Komárom. In muris irrigatis ad molam pagi Környe, 155 m, 21.07.1935, leg. Á. Boros sub Fissidens pusillus BP 94513 (in size, these plants approach $F$. crassipes, but peristome teeth are $37.5-42.5 \mu \mathrm{m}$ wide at base, within the range for $F$. pusillus (51-86 $\mu \mathrm{m}$ in F. crassipes); conf. (F. pusillus) Th. Homm). Bakony Mts (8772.1) Veszprém County. On calcareous rock at the stream at Sombereki-séd at Bakonykoppány in Bakony Mts. N $47^{\circ} 17.917^{\prime}, \mathrm{E} 17^{\circ} 40.279^{\prime}, 280 \mathrm{~m}, 09.10 .2001$, leg. et det. B. Papp (as admixture to $F$. arnoldii (originally determined as $F$. exilis, rev. P. E.) "cum F. pusillus") BP 168495. Mecsek Mts (9776.3) Komitat Baranya, Mecsek-Geb., w Kisújhuta, östl. Máré-vár, Várvölgyi-patak, N 46 13’21.8”, E 18²0’25.2”, 320 m, 28.03.2015, leg. P. Erzberger, J. Deme, J. Csiky, D. Kovács, det. P. Erzberger as F. cf. crassipes, rev. Th. Homm (F. pusillus) (B-Erzberger 19651/a).

The map (Fig. 29) shows the concentration of the records in areas with volcanic bedrock, in particular in the Börzsöny Mts and Visegrád Mts, where recent recording activity was the highest.

Distribution in adjacent countries: Reported from all countries surrounding Hungary and not red-listed in any of them (Hodget Ts 2015).

Literature: DEGEN (1922) reported F. pusillus from the surroundings of Solymár ("auf etwas feuchten schattigen Felsen der Schlucht, die sich an der Ostseite des Felsberges bei Solymár ... herabzieht"), collected 03.06.1917, but no corresponding specimen was found in BP. Another report of the same publication (Holdvilágárok) is supported by several specimens. Most of the records published in PAPP (2009) refer to $F$. gracilifolius.

Note on taxonomic status: According to Bruggeman-Nannenga in HiLL et al. (2006), " $F$. pusillus is treated by North American authors as an expression of $F$. bryoides" (Ann. 102).

Red list status: LC (PAPP et al. 2010), which seems appropriate.

$$
\begin{gathered}
\text { Fissidens rivularis (Spruce) Schimp. } \\
(=\text { F. bryoides var. rivularis Spruce, F. pyrenaicus Spruce) }
\end{gathered}
$$

Plants scattered or in dark green patches, sometimes silt-incrusted, (5-) 7-20 (-25) $\mathrm{mm}$ long, little branched; with brownish, \pm smooth rhizoids at base; leaves numerous, in up to $10-23$ pairs, $1.7-2.9(-3.4) \mathrm{mm}$ long and $0.35-0.7$ $\mathrm{mm}$ wide, (3-) 4-6 times as long as wide, lingulate to lingulate-lanceolate, acute to obtuse and mucronate, apical lamina about as long as sheathing part, dorsal lamina reaching stem and not to shortly decurrent; perichaetial leaves hardly differing from cauline leaves; margin entire; limbidium very stout, yellowish, pluristratose, consisting of several cell rows, usually confluent with excurrent costa at 
leaf apex and forming stout mucro ca $150 \mu \mathrm{m}$ long, (but also very often, either costa reaching the apex, but limbidium grading off into a tissue that is intermediate between costa and border cells, or costa and limbidium both grading off into such a tissue; rarely limbidium and/or costa ending far below apex), not reaching stem at base of dorsal lamina, not rarely branching and in part intramarginal, (16-) 19.5-37 (-54) $\mu \mathrm{m}$ wide in the middle of dorsal lamina, (45-) 50-60 $\mu \mathrm{m}$ wide in sheathing part; costa stout, 50-60 $\mu \mathrm{m}$ wide at mid leaf, yellowish-brownish, excurrent; lamina unistratose, but mostly pluristratose at the base of dorsal lamina, with pluristratose patches often also in the middle of dorsal lamina and in particular near costa; laminal cells irregular hexagonal, thin-walled, 8-10 $\mu \mathrm{m}$ wide in the middle of apical lamina, (5-) 6-11 (-15) $\mu \mathrm{m}$ long and (3-) 5-8 (-10) $\mu \mathrm{m}$ wide in the middle of dorsal lamina; cells in leaf base enlarged, \pm rectangular.

Autoicous; archegonia 250-350 (-380) $\mu \mathrm{m}$ long when ripe, terminal on main shoot or on short or longer lateral shoots originating in leaf axils; antheridia 140-230 (-260) $\mu \mathrm{m}$ long, in bud-like axillary branches. Sporophytes occasional.

Seta (3-) 7-10 $\mathrm{mm}$ long, red, thin and flexuose; capsules slightly inclined to horizontal or \pm erect, ellipsoid, urn 0.6-1.0 (-1.2) mm long; lid conical, rostellate, ca $0.5 \mathrm{~mm}$ long; peristome teeth $42-59 \mu \mathrm{m}$ wide at base, filaments with spiral thickenings; spores (11-) 15-20(-21) $\mu \mathrm{m}$, smooth.

This hydrophilous species is characterised by (i) a strong, bulging limbidium confluent at apex with the excurrent costa in a stout mucro ca $150 \mu \mathrm{m}$ long, (ii) antheridia in bud-like axillary perigonia, and (iii) an often partly bistratose lamina in particular near the costa and at the base of the dorsal lamina.

Similar species:

F. rufulus: limbidium ending below acute leaf apex, 12-24 $\mu \mathrm{m}$ wide in the middle of dorsal lamina; leaves relatively wide, 2.5-4.5 times as long as wide; antheridia terminal ( $F$. rivularis: limbidium confluent with costa in mucronate apex, 16-37 (-54) $\mu \mathrm{m}$ wide in the middle of dorsal lamina; leaves relatively narrow, (3.5-) 4-6 times as long as wide; antheridia in axillary buds, rarely few terminal).

F. bryoides: limbidium less stout and consisting of less cell layers and rows, usually only $2(-3)$-stratose, $7-18 \mu \mathrm{m}$ wide in the middle of dorsal lamina; spores smaller, (9-) 10-14 (-17) $\mu \mathrm{m}$ (F. rivularis: limbidium very stout, to 4-stratose, (16-) 19.5-37 (-54) $\mu \mathrm{m}$ wide in the middle of dorsal lamina; spores 17-20 $\mu \mathrm{m})$.

References: Limpricht (1890: 427-428), MÖNKEMEYER (1927: 140), DEMARET and CASTAGNE (1959: 52-53, 72-74), BRUGGEMAN-NANNENGA (1982: 85, 1985), Sesterhenn (1998), Ahrens (2000: 99-101, 121-122), Cortini Pedrotti (2001: 126-128), Ahrens and Harms (2002), Smith (2004: 240242, 250, 251), CAsAs et al. (2006: 122), GuERrA and EdERrA (2015: 159-161). 
Habitat and substrate: Shaded moist or submerged neutral or acidic rocks, rarely on limestone, in streams, rivers and by lakes.

Distribution in Hungary: Not recorded.

Distribution in adjacent countries: Only in Serbia and Romania (CR); candidate for the new European red list (HodgetTs 2015).

Fissidens rufulus Bruch et Schimp.

(=F. hydrophilus A. Jaeger, F. ventricosus Lesq.)

(Fig. 30)

Plants growing in lax to \pm dense turf or in groups, \pm decumbent, mostly olive-green, brownish green or reddish green, blackish below, 0.3-2.5 $(-3.5) \mathrm{cm}$ long; stem ca 5-15 mm long; sterile shoots to ca $4 \mathrm{~cm}$ long, unbranched or little branched, conspicuously regularly foliated with all leaves forming the same angle of $\pm 60^{\circ}$ with the stem; fertile shoots shorter and often more branched, leaves more crowded, forming smaller angle with the stem; leaves in numerous pairs (10-35), rather uniform in size, cauline leaves $0.8-2.2(-3.0) \mathrm{mm}$ long and $0.2-0.7 \mathrm{~mm}$ wide, $2.5-4.5$ times as long as wide, perichaetial leaves \pm similar to stem leaves, $1.5-2.7 \mathrm{~mm}$ long, leaves lingulate lanceolate to ovate lanceolate or oblong lanceolate, apex short, \pm short and broad, not to indistinctly acuminate (apex obtuse in sterile plants, acute in fertile plants); apical lamina shorter than sheathing part to equal in length; dorsal lamina extending to leaf base and somewhat decurrent along stem; leaf margin entire or indistinctly denticulate above; limbidium strongly developed, bulging, pluristratose and consisting of several rows of cells, red-brown in older leaves, ending below leaf apex, at the middle of dorsal lamina $12-25 \mu \mathrm{m}$ wide, in sheathing part 37-50 (-60) $\mu \mathrm{m}$ wide, extending to leaf insertion; costa stout, (30-) 40-60 $\mu \mathrm{m}$ wide at mid leaf, in older leaves reddish brown, mostly vanishing a few cells below apex; lamina unistratose (but occasionally pluristratose near insertion), cells thin-walled to slightly incrassate, with yellow-brown walls, in upper part of leaf irregularly hexagonal, small, ca (6-) 8-12 $\mu \mathrm{m}$ long (measured in the direction of their greatest extension), in the middle of the dorsal lamina (6-) 7-11 (-15) $\mu \mathrm{m}$ long and 4-9 (-11) $\mu \mathrm{m}$ wide, $8-10(-12) \mu \mathrm{m}$ wide in the middle of apical lamina.

Dioicous or synoicous; archegonia 300-460 (-560) $\mu \mathrm{m}$ long, terminal; antheridia $250-400 \mu \mathrm{m}$ long, terminal. Sporophytes in general not rare.

Seta terminal, reddish, 2.5-6 (-7) mm long; capsules mostly symmetric, erect, rarely weakly inclined, (0.4-) 0.6-1.0 (-1.4) mm long, ellipsoid; lid conical, rostrate, to $0.44 \mathrm{~mm}$ long; peristome teeth at their base (37-) 43-66 (-71) $\mu \mathrm{m}$ wide, filaments papillose, with distinct spiral thickenings; spores (15-) 18 $26(-35) \mu \mathrm{m}$, finely papillose. 
This aquatic species is characterised by (i) rather small laminal cells $4-9 \mu \mathrm{m}$ wide and 7-11 $\mu \mathrm{m}$ long, (ii) often long shoots regularly foliated with many (1035) leaf pairs, and (iii) terminal antheridia and archegonia.

Similar species:

F. crassipes: leaves of well-developed plants forming an angle of $45^{\circ}$ with stem; leaves widest at middle and gradually narrowed towards apex; laminal cells

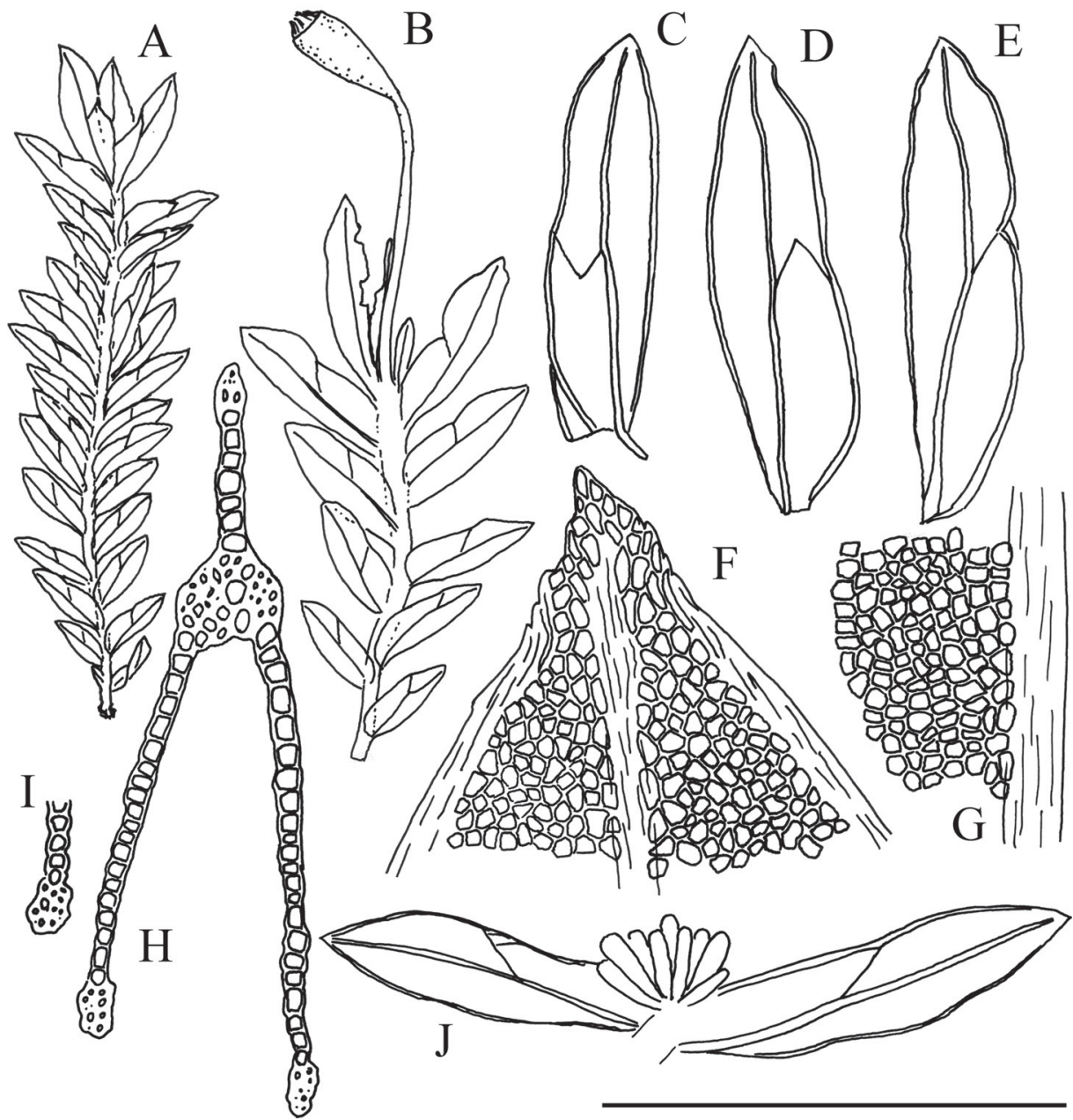

Fig. 30. Fissidens rufulus: A, B = habit of sterile and fruiting plants; C, D, E = leaves; F = leaf apex; $\mathrm{G}=$ laminal cells at middle of dorsal lamina; $\mathrm{H}=$ transverse section of leaf; $\mathrm{I}=$ transverse section of limbidium at vaginant lamina; $\mathrm{J}=$ terminal antheridia with two leaves. Scale bar: A - $7.2 \mathrm{~mm}$; B - 4.6 mm; C, D, E, J - 2 mm; F, G, H, I - $200 \mu \mathrm{m}$ [Erzberger s. n. (Germany, Hoppecketal, leg. C. Schmidt 1995, conf. M. A. Bruggeman-Nannenga)]. 
9-23 (-26) $\mu \mathrm{m}$ long, archegonia 420-660 $\mu \mathrm{m}$ long, peristome teeth at their base 51-86 $\mu \mathrm{m}$ wide (F. rufulus: leaves of well-developed plants forming an angle of $60^{\circ}$ with stem; leaves parallel-sided and more suddenly narrowed towards apex; laminal cells (6-) 7-11 (-15) $\mu \mathrm{m}$ long, archegonia 300-460 (-560) $\mu \mathrm{m}$ long; peristome teeth at their base (37-) 43-66 (-71) $\mu \mathrm{m}$ wide).

The reddish border in F. rufulus and the presence or absence of an intralaminal limbidium are not reliable characters for the distinction of the two species.

F. pusillus: stems usually smaller, mostly not more than $6.5 \mathrm{~mm}$ long; spores (9-) 10-18 (-23) $\mu \mathrm{m}$; peristome teeth (24-) 30-47 (-53) $\mu \mathrm{m}$ wide at base (F. rufulus: stems often $>6.5 \mathrm{~mm}$ long; spores (15-) 18-26 (-29) $\mu \mathrm{m}$; peristome teeth (37-) 43-66 (-71) $\mu \mathrm{m}$ wide at base).

F. rivularis: see the note under that species.

References: LIMPRICHT (1890: 425-426, 443-444), Demaret and CASTAGNE (1959:52-53,66-70), BRUGGEMAN-NANNENGA (1982: 80-86), NYHOLM (1987: 8-9), Bruggeman-Nannenga (1989: 77-78), Ahrens (2000: 99-101, 122-123), Bijlsma (2000), Cortini Pedrotti (2001: 125-126), Smith (2004: 240-242, 251-252), GUERRA and EDERRA (2015: 168-169).

Habitat and substrate: Inundated zone of rivers and streams, preferably on limestone, but also on acid rocks.

Distribution in Hungary: Not recorded.

Distribution in adjacent countries: In all countries surrounding Hungary, but doubtful in Slovenia, red-listed in Austria (3, corresponds to EN), CR in Romania, R in Ukraine, and VU in Slovakia; candidate for the new European red list (HodgetTs 2015).

Fissidens serrulatus Brid.

(Fig. 31)

Plants in lax green tufts or patches, $1-6(-7.5) \mathrm{cm}$ long, stems procumbent to erect, simple or branched; leaves in numerous (8-25) pairs, 5-7 mm long, 0.8-1.2 $\mathrm{mm}$ wide, oblong-lanceolate to lingulate, shortly acuminate to obtuse and apiculate; dorsal lamina rounded at base, not to sometimes slightly decurrent; elimbate, leaf margin irregularly toothed near apex, denticulate below, 3-4 (5-8 in vaginant laminae) marginal rows of strongly incrassate pellucid smooth cells differentiated in pale band; costa ending in or below apex, 70-120 $\mu \mathrm{m}$ wide in mid leaf; laminal cells rounded hexagonal, incrassate, conically mamillose on both surfaces, partially bistratose, $10-16 \mu \mathrm{m}$ wide in the middle of apical lamina.

Spherical or irregular rhizoidal tubers, to $800 \mu \mathrm{m}$, reddish brown to blackish, often present.

Dioicous, antheridia axillary or terminal. 
Seta terminal, yellowish, thick, flexuose, $1.4-2 \mathrm{~cm}$ long; capsule inclined to horizontal, ovoid, dark brown; lid longly rostrate; spores $12-16 \mu \mathrm{m}$.

This robust species is characterised by (i) elimbate leaves coarsely serrulate at apex, (ii) with a pale band of 3-5 rows of marginal cells, and (iii) incrassate laminal cells, 10-16 $\mu \mathrm{m}$, conically mamillose on both surfaces.

Similar species:

F. adianthoides: laminal cells not to slightly bulging, slightly larger, (10-) $12-18(-20) \mu \mathrm{m}$; leaves less long and relatively wider, ca $1.5-3 \mathrm{~mm}$ long and $0.5-$ $1.0 \mathrm{~mm}$ wide (F. serrulatus: laminal cells conically mamillose, smaller, 10-16 $\mu \mathrm{m}$; leaves 5-7 mm long, relatively narrower).

References: Cortini Pedrotti (2001: 140-142), Smith (2004: 258-260), GuERra and EDERra (2015: 179-181).

Habitat, substrate: On alluvial sand and gravel and on rocks below flood level of deeply shaded streams in ravines, lowland (British Isles), shaded soil or rocks along water courses (Italy, Iberic Peninsula).

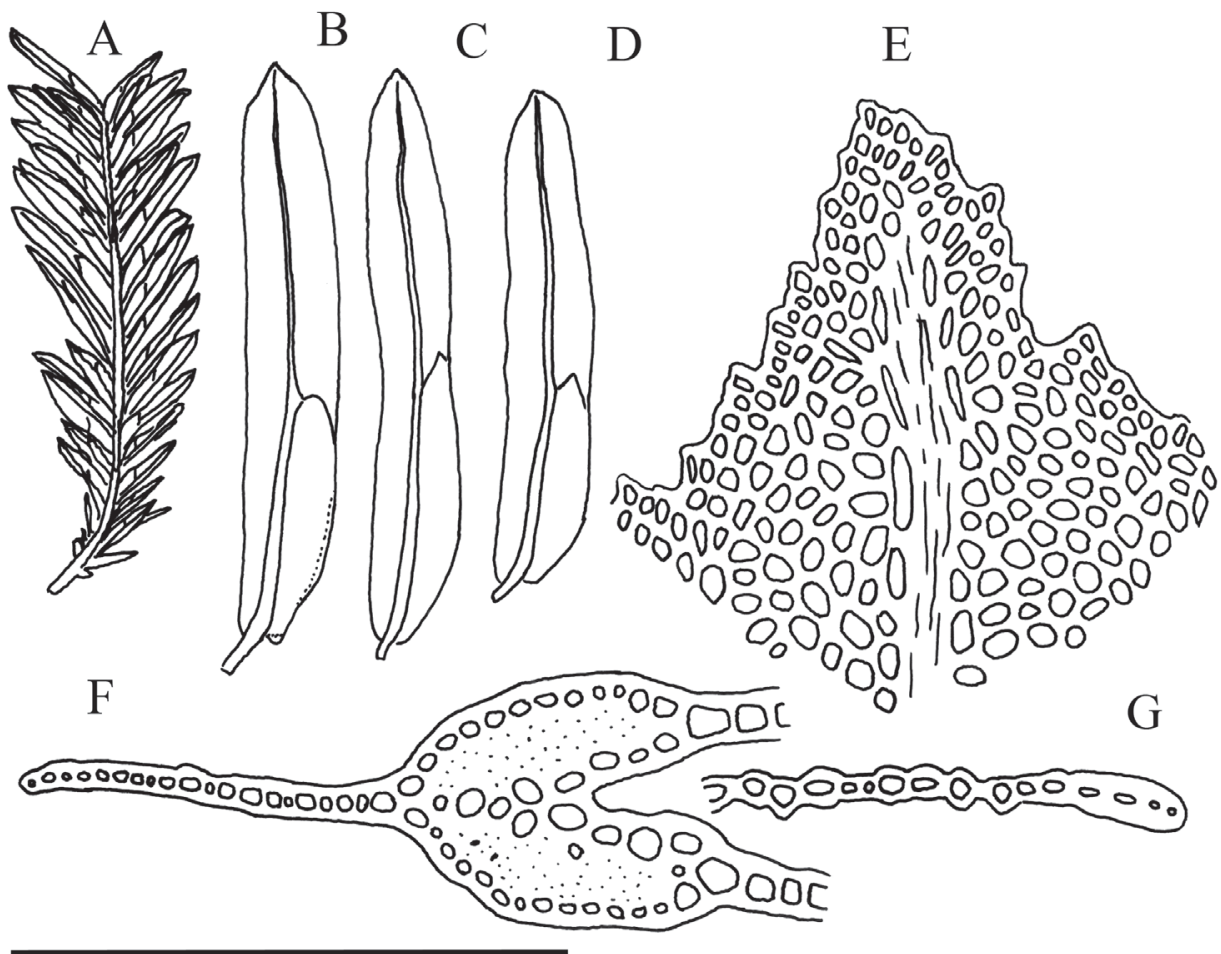

Fig. 31. Fissidens serrulatus: $\mathrm{A}=$ habit; $\mathrm{B}, \mathrm{C}, \mathrm{D}=$ leaves; $\mathrm{E}=$ leaf apex; $\mathrm{F}=$ transverse section of leaf; $\mathrm{G}=$ detail of transverse leaf section in apical part. Scale bar: A - $17.5 \mathrm{~mm}$; B, C, D - $4.6 \mathrm{~mm}$; E, F, $\mathrm{G}-200 \mu \mathrm{m}$ [Erzberger 1684 (Spain, Tenerife 1995)]. 
Distribution in Hungary: Not recorded.

Distribution in adjacent countries: Slovenia, Croatia, Serbia; red-listed in Slovenia (EN) (HodgetTs 2015).

\section{Fissidens taxifolius Hedw.}

(Figs 32, 33)

Plants in lax or \pm dense groups, vivid green to light green, yellowish green or dark green, decumbent to erect, to $c$ a 1-2.5 (-4) cm long, branched at their base; leaves in numerous (5-24) pairs, 1.5-2.2 (-2.5) mm long and 0.5-0.75 (-0.9) $\mathrm{mm}$ wide, lingulate lanceolate, oblong lanceolate or ovate lanceolate, quickly narrowed to a short, acute to obtuse, mucronate apex; apical lamina mostly much shorter than sheathing part, dorsal lamina extending to leaf insertion and slightly decurrent to not decurrent; elimbate, margin finely and regularly crenulate to serrulate by protruding cell corners, 1 row of marginal cells mostly more pellucid and incrassate than adjacent cells; costa stout, mostly excurrent as a short mucro (in particular in uppermost leaves) or percurrent, $40-55 \mu \mathrm{m}$ wide at mid leaf; lamina unistratose, laminal cells in upper part of leaf \pm hexagonal, bulging, opaque, cells of sheathing part each with a blunt conical abaxial mamilla, thinwalled to \pm incrassate, in the middle of dorsal lamina 6-12 (-15) $\mu \mathrm{m}, 6-10 \mu \mathrm{m}$ wide in the middle of apical lamina, often differing much in size; cells in upper leaves of stem often larger than cells of lower leaves.

Rhizoidal tubers, \pm spherical, 300-700 $\mu \mathrm{m}$ diameter, colourless when young, turning dark red to nearly black when old, sometimes present near the base of plants.

Autoicous or dioicous, archegonia and antheridia mostly in short, bud-like branches near the base of the stem, archegonia $300 \mu \mathrm{m}$ long, antheridia $120 \mu \mathrm{m}$ long; sporophytes occasional to frequent, sometimes abundant (in 13\% of specimens seen).

Seta originating near stem base, yellowish to reddish, 8-12 (-15) $\mathrm{mm}$ long, sometimes slightly flexuose; capsules inclined to horizontal, slightly curved and asymmetric, ca 1-1.5 mm long, elongate ovate to ellipsoid, wide-mouthed when empty, contracted below mouth when dry; lid conical, about as long as the urn, longly and obliquely rostellate; peristome teeth 75-90 $\mu \mathrm{m}$ wide at base, upper portion of filaments nodose, papillose, without spiral thickenings; spores ca 12$18(-20) \mu \mathrm{m}$, smooth or almost so, ripening from autumn to spring.

This mostly medium-sized, but sometimes small or robust species is characterised by (i) cuspidate leaves with excurrent costa, (ii) limbidium lacking on all laminae, (iii) margin finely crenulate, not coarsely serrate at apex, (iv) bulging laminar cells except for one cell row of marginal cells appearing paler than adjacent laminal cells, and when present, (v) seta originating near stem base. 
Variability: F. taxifolius var.pallidicaulis (Mitt.) Corb. in Pitard et Negri is an Oceanic Southern-Temperate taxon (listed in Hodgetrs 2015 for Croatia and Serbia among the countries adjacent to Hungary) that differs from the typical variety mainly in the following characters: shoots taller, to $3 \mathrm{~cm}$ long (in Madeira to $6 \mathrm{~cm}$ long), leaves mostly lanceolate to linear lanceolate, tapering from end of sheathing laminae to acuminate apex; cells 7-9 $\mu \mathrm{m}$ wide in the middle of apical lamina, of doubtful taxonomic value (GUERRA and EDERRA 2015).

Similar species:

F. adianthoides: leaf margin coarsely serrate near apex at least in uppermost leaves with irregular alternation of larger and smaller teeth; pale band of slightly incrassate marginal cells ca 3 cell rows wide; seta originating in the middle of shoots; leaf cells large, flat, leaves therefore translucent ( $F$. taxifolius: leaf margin finely and regularly crenulate without larger teeth; pale marginal band usually only $1(-2)$ cell row(s) wide; seta originating at the basis of stems; leaf cells smaller, bulging, leaves therefore opaque).

F. dubius: leaf margin coarsely serrate near apex at least in uppermost leaves with irregular alternation of larger and smaller teeth; pale band of slightly in-

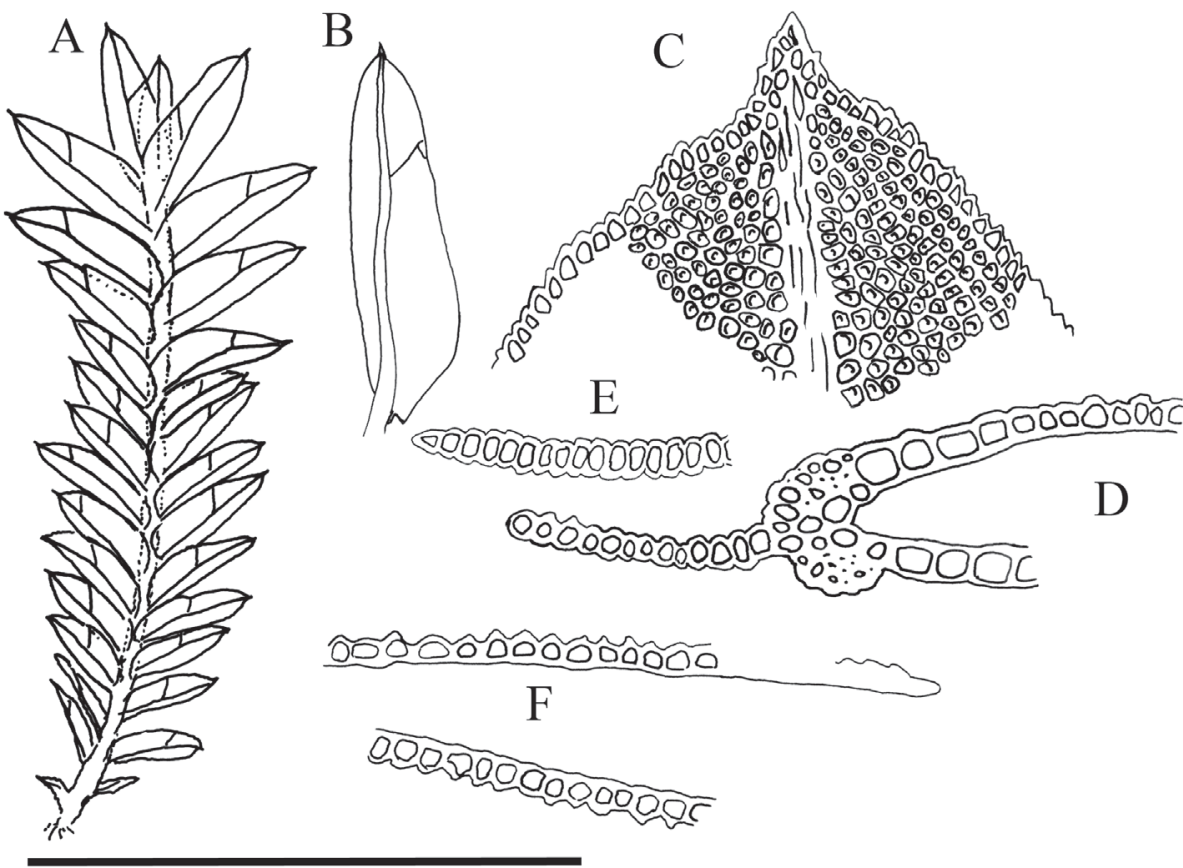

Fig. 32. Fissidens taxifolius: $\mathrm{A}=$ habit; $\mathrm{B}=$ leaf; $\mathrm{C}=$ leaf apex; $\mathrm{D}, \mathrm{E}, \mathrm{F}=$ details of transverse leaf sections (D: costa and dorsal lamina; E: apical part; F: sheathing part). Scale bar: A - $4.6 \mathrm{~mm}$; B - 2 mm; C, D, E, F - $200 \mu \mathrm{m}$ [A: Erzberger s. n. (Csobánka 1991); B, C, D, E, F: Erzberger 7359]. 
crassate marginal cells ca 3 cell rows wide; costa often ending below apex, but shortly excurrent in var. mucronatus; seta originating in the middle of stems, rarely near the basis; leaf margins nearly parallel sided and rather abruptly angled in at tip; colour of dried specimens yellowish, \pm glossy ( $F$. taxifolius: leaf margin finely and regularly crenulate without larger teeth; pale marginal band usually only $1(-2)$ cell row(s) wide; costa excurrent in stout mucro; seta originating at the basis of stems; leaf margins \pm gradually tapering in upper $1 / 4$ of leaf; colour of dried specimens often pale greenish, rarely yellowish, dull).

F. osmundoides: seta terminal; laminal cells greater, 10-20 $\mu \mathrm{m}$, often more than $12 \mu \mathrm{m}$; costa rarely percurrent, not excurrent ( $F$. taxifolius: seta originating near stem base; laminal cells mostly less than $12 \mu \mathrm{m}$; costa mostly excurrent).

F. exilis: see note under that species.

References: Limpricht (1890: 452-454), Demaret and CASTAgne (1959: 52-53, 77-79), Nyholm (1987: 8, 13), Bruggeman-Nannenga (1989: 77, 87), Ahrens (2000: 99-101, 123-124), Cortini Pedrotti (2001: 136-139), Smith (2004: 240-243, 255-257), Atherton et al. (2010: 415), Guerra and EDERRA (2015: 185-187).

Habitat and substrate: On loamy calcareous bare soil in damp, shaded places.

Associated bryophytes: Amblystegium serpens, Anomodon attenuatus, Anthoceros agrestis, Atrichum angustatum, $A$. undulatum, Barbula convoluta, Brachythecium velutinum, Bryum pallens, B. rubens, B. cf. subapiculatum, Calliergonella

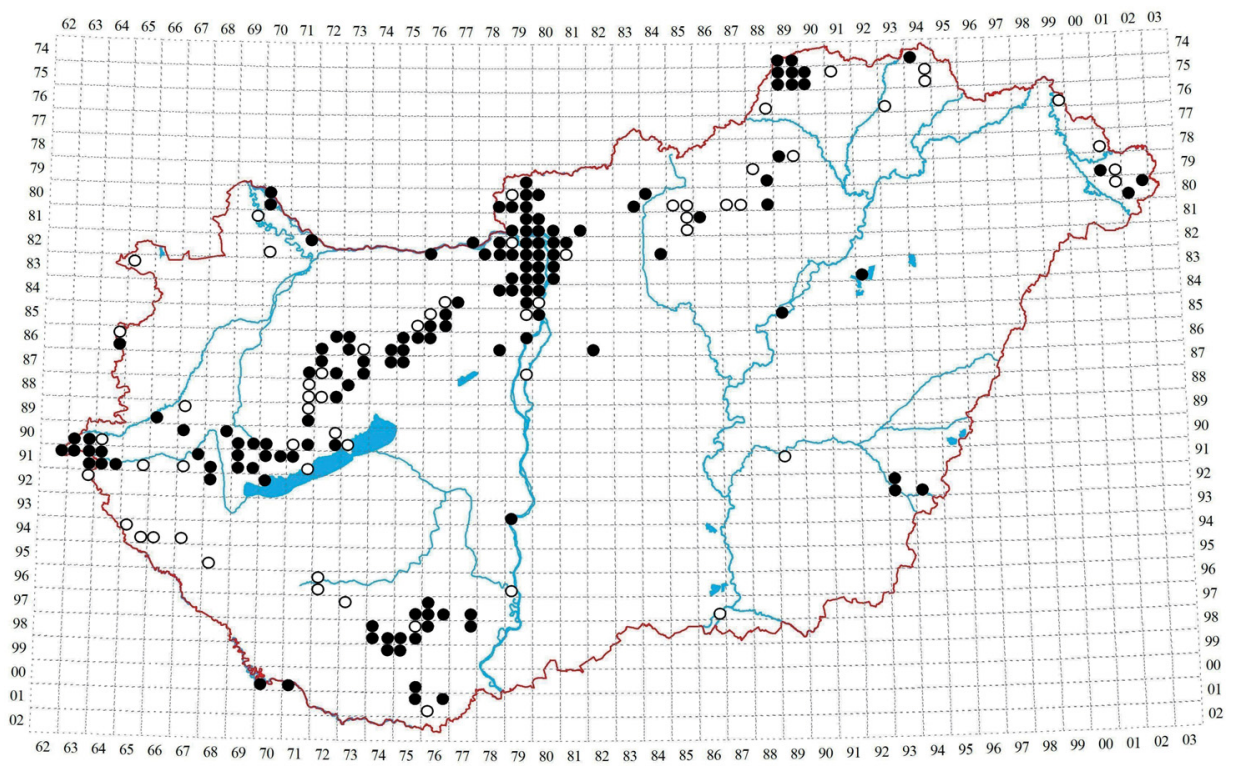

Fig. 33. Records of Fissidens taxifolius. 
cuspidata, Campylium calcareum, C. elodes, Cephaloziella divaricata, Ceratodon purpureus, Chiloscyphus pallescens, Ctenidium molluscum, Dicranella heteromalla, Didymodon fallax, D. rigidulus, Ditrichum flexicaule, Encalypta streptocarpa, Ephemerum minutissimum, Eurhynchium hians, E. striatulum, Fissidens bryoides, F. dubius, F. exilis, F. incurvus, F. taxifolius, F. viridulus, Fossombronia wondraczekii, Hypnum cupressiforme, Leptodictyum riparium, Lophocolea bidentata, L. minor, Metzgeria conjugata, Mnium stellare, Phascum cuspidatum, Plagiochila porelloides, Plagiomnium affine, P. cuspidatum, P. undulatum, Plagiothecium nemorale, Platyhypnidium riparioides, Pleuridium subulatum, Pohlia melanodon, Pottia truncata, Rhizomnium punctatum, Rhynchostegium murale, Thuidium philibertii, Tortella tortuosa, Tortula subulata, Weissia brachycarpa c. spg., W. controversa.

Vertical distribution: 83-900 $\mathrm{m}$ a.s.1.

Distribution in Hungary: (> 300 specimens, 130 additional field data, 198 grid cells, of which 140 represent recent finds). Recorded in all regions except Cserehát Hills, Putnok Hills, Cserhát Hills, Velence Mts, Fertő Hills, Örség, Hetés, Göcsej, Külső Somogy, Hanság, Nyírség, but can probably be found there too. Specimen quotation seems unnecessary.

Distribution in adjacent countries: In all countries surrounding Hungary, and not red-listed in any of them (HodGetTs 2015).

Literature: BOROS (1968) and ORBÁN and VAJDA (1983) give general information, but state that the species is rarer in the lowlands.

Red list status: LC (PAPP et al. 2010), which is appropriate.

Fissidens viridulus (Sw.) Wahlenb.

(= Dicranum viridulum Sw., F. bryoides var. viridulus (Sw.) Broth., F. bryoides subsp. viridulus (Sw.) Kindb., F. bryoides var. hedwigii Limpr., F. bryoides var. intermedius R. Ruthe, F. impar Mitt.)

(Figs 34, 35)

Plants small, growing in lax groups, mostly vivid green or yellowish green, usually only 1-1.5 mm wide, to ca 6-7 mm long, stems (2.5-) $3.5(-6) \mathrm{mm}$ long, simple or little branched, central strand weakly differentiated or absent; leaves in 3-4 (-8) pairs, uppermost distinctly larger than lower leaves; cauline leaves (0.7-) 0.9-1.6 mm long and 0.15-0.45 mm wide, (2.5-) 3-6 times as long as wide; perichaetial leaves 1.1-1.9 (-2.3) mm long; leaves lanceolate, oblong lanceolate or lingulate lanceolate, suddenly or gradually narrowed to a weak or fairly stout short, acute (and then mostly weakly to distinctly acuminate) to subobtuse point; apical lamina about as long as or longer than sheathing part, dorsal lamina extending to leaf insertion and sometimes slightly decurrent; margin entire or obscurely denticulate towards apex; limbidium well developed, narrow, unistra- 
tose and consisting of one row of cells (wider only in vaginant laminae), at the middle of dorsal lamina (0-) 4-11 (-15) $\mu \mathrm{m}$ wide, colourless or pale yellow, extending down to leaf insertion, vanishing at or below leaf apex, in \pm acuminate leaves nearly reaching the apex but not confluent with the costa; costa 25-30 $\mu \mathrm{m}$ wide at mid leaf, percurrent or vanishing below leaf apex; lamina unistratose, cells in upper part of leaf irregularly hexagonal, (9-) 12-16 (-18) $\mu \mathrm{m}$ long and $8-10 \mu \mathrm{m}$ wide, in the middle of the dorsal lamina (9-) 10-15 (-18) $\mu \mathrm{m}$ long and 6-12 $\mu \mathrm{m}$ wide, (6-) 8-15 $\mu \mathrm{m}$ wide in the middle of apical lamina.

Rhizoidal tubers, nearly spherical, dark brown, diameter $c a 110 \mu \mathrm{m}$, rarely present.

Autoicous, dioicous or polyoicous, archegonia (280-) 310-380 (-410) $\mu \mathrm{m}$ long, mostly terminal, rarely axillary, naked immediately below a perichaetium; antheridia $140-220 \mu \mathrm{m}$ long, usually terminal, mostly in small bud-like or sometimes greater plants or shoots (usually with 3 pairs of leaves), at the base of female plants or solitary, rarely axillary in bud-like branches at the base of female plants. Sporophytes regularly present, often abundant (in $67 \%$ of specimens seen).

Seta terminal, yellow, becoming reddish with age, (1.5-) $2.5-7 \mathrm{~mm}$ long, thin, geniculate at base; capsules erect to rarely slightly inclined, \pm symmetric, 0.5-1.0 mm long, ellipsoid to elongate-ovate; lid conical, rostrate; peristome teeth at their base (30-) 34-60 (-68) $\mu \mathrm{m}$ wide; spores (9-) 14-18 (-20) $\mu \mathrm{m}$, smooth or nearly so, ripening from October to May.

This small limbate species is characterised by (i) the limbidium nearly reaching the leaf apex, but not confluent with the costa, (ii) antheridia mostly in dwarf male plants, (iii) erect, symmetric capsules, and (iv) growing on basic soil.

Similar species:

F. bryoides: plants larger, to $1(-2) \mathrm{cm}$ long; antheridia usually in axillary bud-like branches; limbidium usually pluristratose and confluent with mostly excurrent costa, stem with developed central strand (F. viridulus: plants smaller, to $6(-7) \mathrm{mm}$ long; antheridia usually terminal, very rarely axillary; limbidium unistratose and vanishing below leaf apex or in \pm acuminate leaves nearly reaching the apex but not confluent with the costa; stem without or with weakly differentiated central strand).

F. crispus: dry leaves usually crispate; laminal cells strongly bulging on both faces and about twice as high as wide in cross section (F. viridulus: dry leaves usually not crispate; laminal cells flat, not bulging, about as wide as high in cross section).

F. incurvus: capsules asymmetric, (strongly) inclined; leafpoint stouter, limbidium often confluent with costa at apex; seta strong, red; limbidium pluristratose (F. viridulus: capsules symmetric, mostly erect, rarely slightly inclined; leaf 
apex with a less stout point, limbidium not confluent with costa at apex; seta yellow, weaker; limbidium unistratose).

F. gracilifolius: growing on and firmly adhering to \pm moist, shaded limestone rocks; leaves much narrower and more acuminate (F. viridulus: growing on soil and not firmly attached to its substrate; leaves broader and less acuminate).

F. pusillus: growing directly on siliceous rock and firmly attached to it; leaf tip with straight to convex sides, limbidium ending below leaf tip; hydrophilous (F. viridulus: growing on calcareous soil, not firmly adhering to substrate; leaf tip with concave sides, limbidium nearly reaching tip; mesophytic to hygrophytic).

F. bambergeri, F. exiguus, F. gymnandrus: see notes under these species.

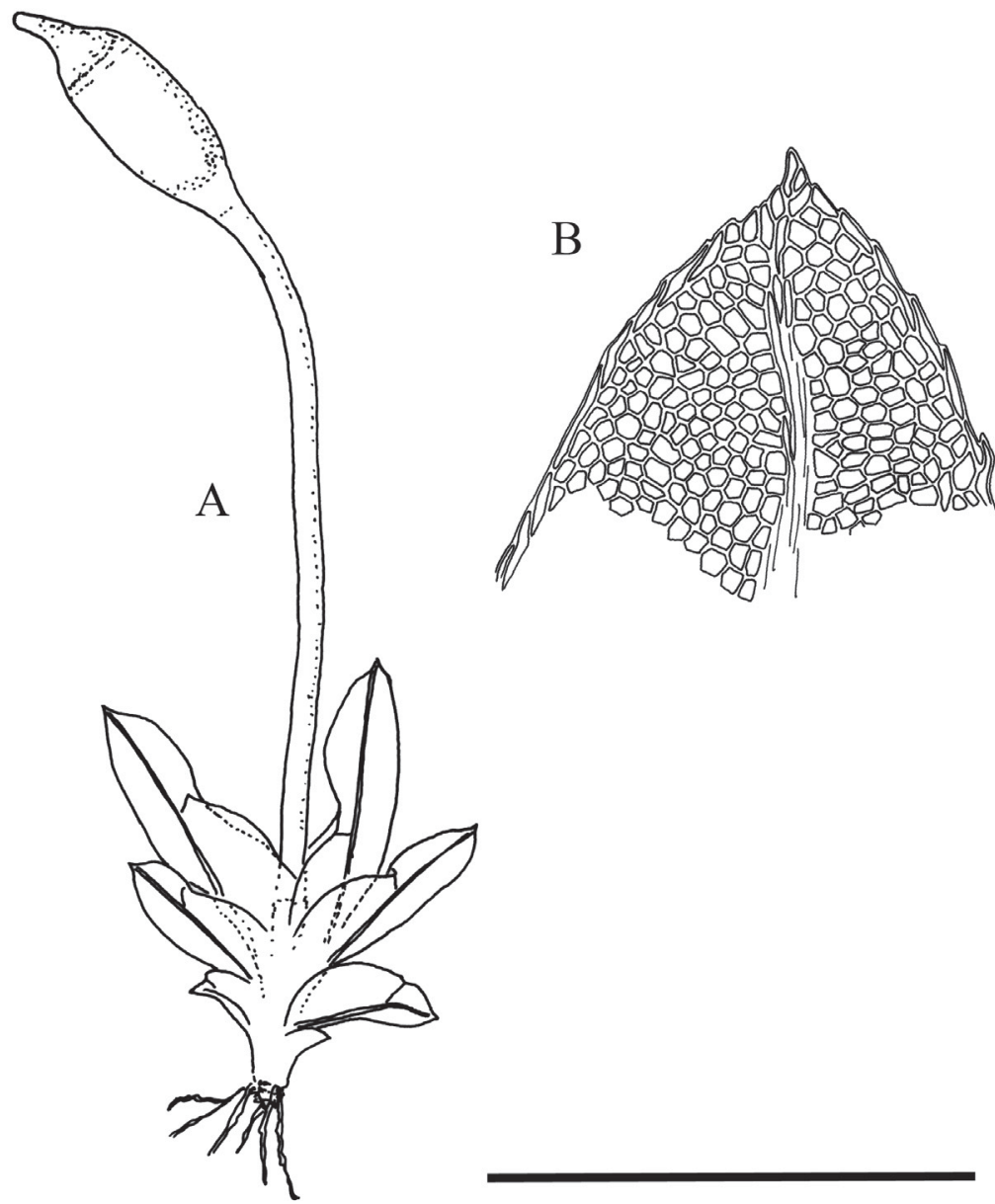

Fig. 34. Fissidens viridulus: $\mathrm{A}=$ habit of plant with sporophyte; $\mathrm{B}=$ leaf apex. Scale bar: $\mathrm{A}-2 \mathrm{~mm}$; B - $200 \mu \mathrm{m}$ [Erzberger 21148]. 
References: Demaret and Castagne (1959: 52, 55-57), Nyholm (1987: 8, 11), Bruggeman-Nannenga (1989: 77, 82-84), Ahrens (2000: 99-101, 125-126), Cortini Pedrotti (2001: 131-133), Smith (2004: 241-245), Atherton et al. (2010: 404, 405), GUERrA and EdERRA (2015: 170-171).

Habitat and substrate: On basic to slightly acidic, clayey, moist, shaded soil, in soil-cuttings, on stream banks, in woodland, amongst rocks and on thin soil overlying rock, in \pm calcareous regions.

Associated bryophytes: Amblystegium serpens, Anomodon attenuatus, Atrichum undulatum, Brachythecium velutinum, Bryum argenteum, B. rubens, Calliergonella cuspidata, Campylium calcareum, Ctenidium molluscum, Didymodon rigidulus, D. vinealis, D. sinuosus, Distichium capillaceum, Encalypta streptocarpa, Eurhynchium hians, Fissidens dubius, F. taxifolius, Lophocolea minor, Myurella julacea, Orthothecium intricatum, Phascum cuspidatum var. cuspidatum, Plagiochila porelloides, Plagiomnium affine, Pogonatum sp., Pohlia cruda, Pottia truncata, Reboulia hemisphaerica, Scapania calcicola, Tortula subulata, Weissia controversa, Weissia sp.

Vertical distribution: $85-875 \mathrm{~m}$ a.s.l.

Distribution in Hungary: ( 92 specimens, 59 grid cells of which 43 represent recent finds). - Zemplén Mts (7494.2) Borsod-Abaúj-Zemplén County, Zemplén Mts, around the Felsőmalmi erdészház (forestry house) at Füzér N 48³3'08.8”, E $21^{\circ} 27^{\prime} 13.3 ”, 460$ m, 22.08.2005, leg. et det. B. Papp BP 180316. Aggtelek Karst (7489.4) Comit. Borsod-Abaúj-Zemplén. In Piceetum cultivatum ad Szelcepuszta prope pag. Aggtelek, 360 m, 09.11.1989, leg. B. Papp sub Fissidens gracilifolius BP 166338. Putnok Hills (7688.4 or 7788.2) Comit. Gömör. In argillosis ad margines silv. pedis montis Nagykő pr. Putnok, 250-350 m, 31.10.1937, leg. Á. Boros BP 94155. Bükk Mts (7889.3 or 7989.1) Comit. Borsod. In silvis ad Nagymező prope Jávorkút, $770 \mathrm{~m}, 26.09 .1952$, leg. Á. Boros (admixture to F. dubius) BP 93452. Mátra Mts (8186.1) Comit. Heves. In rupestribus andesiticis silvat. sept. Sorkő montis Sombokor prope Parád, 850-900 m, 19.04.1952, leg. Á. Boros sub Fissidens bryoides BP 94137. Cserhát Hills (8181.4) Pest County, Csővár, beside forest road towards Vár-hill, on soil in oak forest, N 47 49' 20.0”, E 19 $18^{\circ}$ 46.4”, 230 m, 26.03.2014, leg. P. Erzberger and Cs. Németh (B-Erzberger 17242). Börzsöny Mts (8079.4) Komitat Pest, Szokolya, Királyrét, Börzsöny-Geb., südl. Szállás-bérc, N 47 55’39.0”, E $18^{\circ} 57^{\prime} 06.1$ ”, 640 m, 14.11.2015, leg. J. Nagy and P. Erzberger (B-Erzberger 21148). Visegrád Mts (8279.4) Komitat Pest, Gde. Pilisszentlászló, Tal Apátkúti völgy, Wiese unweit des Ortes, 04.02.1994, leg. et det. P. Erzberger, conf. Th. Homm (B-Erzberger 726). Buda Mts (8479.2) Budapest County, Budapest, [recte: Pest County, Nagykovácsi] Remete-hegy at Budaliget, dry oak forest, on soil N 47 33'39.7”, E $18^{\circ} 55^{\prime} 37.6^{\prime \prime}, 370 \mathrm{~m}$, 27.05.2006, leg. et det. B. Papp BP 173044. Gerecse Mts (8276.3) KomáromEsztergom County, Dunaszentmiklós, Nagy-Som-hegy, on soil near the cave, N 
$47^{\circ} 42^{\prime} 20.7^{\prime \prime}, \mathrm{E} 18^{\circ} 24^{\prime} 25.2^{\prime \prime}, 400$ m, 29.05.2015, leg. Cs. Németh and P. Erzberger (B-Erzberger 19977). Vértes Mts (8675.2) Fejér County, Vértes Mts, Csákberény, Ugró valley at Szentegyházi hill, limestone cliff N $47^{\circ} 22^{\prime} 04.2^{\prime \prime}, \mathrm{E} 18^{\circ} 19^{\prime} 11.8^{\prime \prime}$, 380 m, 17.04.2011, leg. et det. B. Papp BP 182076. Velence Mts (8777.2) Fejér County, Nadap, Meleg-hegy, on soil near path, N $47^{\circ} 15^{\prime} 14.1^{\prime \prime}$, E $18^{\circ} 36^{\prime} 04.5^{\prime \prime}$, 260 m, 27.05.2014, leg. P. Erzberger and P. Szücs (B-Erzberger 17790). Bakony Mts (8773.4) Komitat Veszprém, Eplény, auf etwas ausgehagerten Erdblössen am Gipfel des Berges Prédikálószék; Dolomit-Grundgestein, N 47² 12’ 48.9”, E 1755’ 33.2", 400 m, 05.04.2014, leg. Cs. Németh and P. Erzberger (B-Erzberger 17466). Balaton uplands (9171.3) Comit. Zala. In humosis inter saxa basalt. Páholy montis Badacsony prope Badacsony, 400 m, 29.04.1956, leg. Á. Boros sub Fissidens bryoides BP 94087. Keszthely Mts (9169.3) Zala County, Rezi, surroundings of shaded dolomitic rock group Csóka-kő, steep slope in northern exposition, broadleaved forest, $\mathrm{N} 46^{\circ} 49^{\prime} 02.0^{\prime \prime}$, E 17 14’ 17.0”, 255 m, 24.10.2015, leg. Cs. Németh, P. Erzberger, B. Papp and A. Kovács (B-Erzberger 20951). Kőszeg Mts (8664.4) Kom. Vas, Kőszegi-hg., Bozsok, Tal des Baches Bozsoki-patak, N $47^{\circ} 20^{\prime} 14.7^{\prime \prime}$, E 16² 29' 01.3”, 440 m, 05.11.2015, leg. P. Erzberger, K. Baráth and A. Kausits (B-Erzberger 21082). Vendvidék (9063.4) Comit. Vas. In argillosis ad margines fruticetorum ad pagum Zsida, 240 m, 02.04.1933, leg. Á. Boros sub Fissidens bryoides BP 94792, dupl. BP 138. Örség (9164.2) Com. Vas. pr. pg. Kondorfa. Alnetum incanae prope Lugos patak, 18.05.1953, leg. T. Pócs sub Fissidens bryoides BP 94790. Vas (locali-

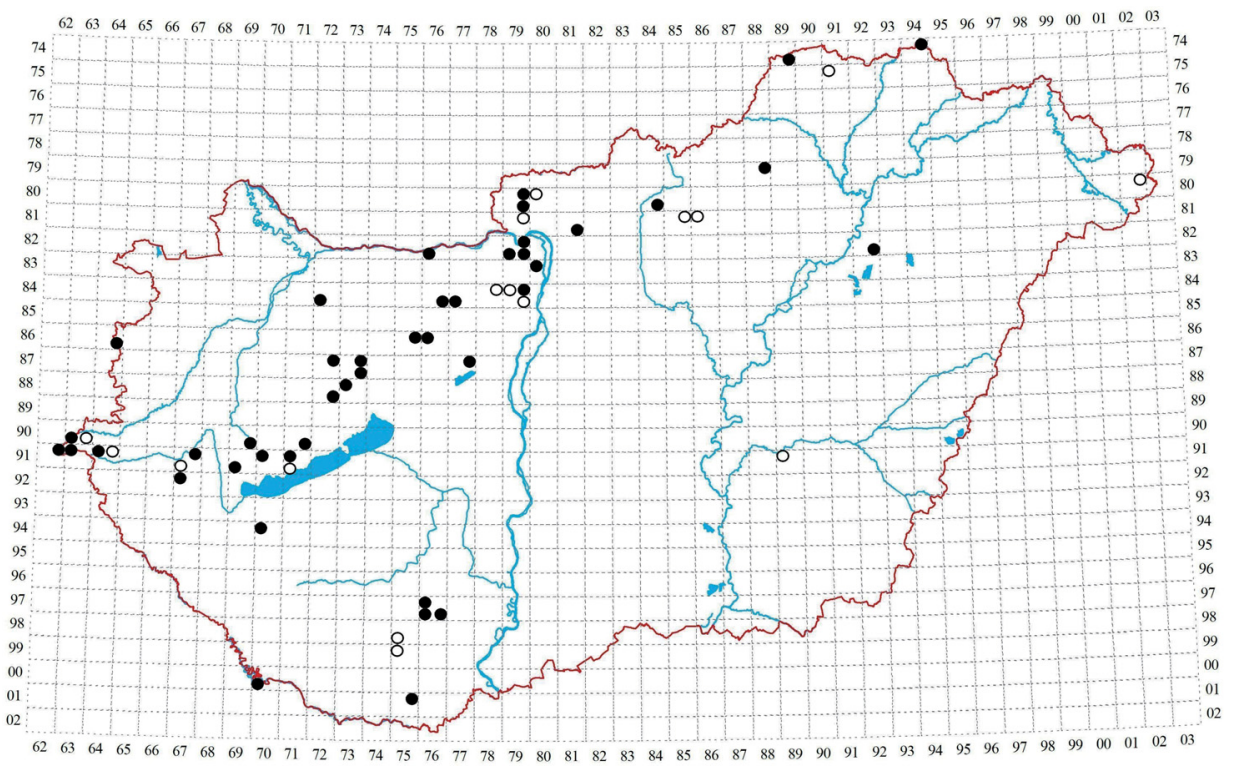

Fig. 35. Records of Fissidens viridulus. 
sation inexact) Comit. Vas. In argillosis ad ripam fluvii Rába ad Berkimajor prope Vasvár, 170 m, 02.11.1930, leg. Á. Boros (as admixture to F. taxifolius) BP 93620. Zala (9167.3) Comit. Zala. Prope pag. Csácsbozsok, 10.06.1948, leg. A. Visnya det. Á. Boros as Fissidens bryoides BP 94778. Külső Somogy (9470.1) Somogy County, Marcali-Kisgomba, Öreg-hegy, on soil beside vineyard, N $46^{\circ} 34^{\prime} 39.4^{\prime \prime}, \mathrm{E}$ $17^{\circ} 23^{\prime} 21.5^{\prime \prime}, 200 \mathrm{~m}, 22.09 .2014$, leg. P. Erzberger and T. Pócs (B-Erzberger 18817). Mecsek Mts (9776.4) Baranya County, between Óbánya and Mecseknádasd, west side of Templom-hill (Sz.-Imre-hegy), Fagetum nudum on steep slope with siliceous, but base-rich scree, on small phonolith stone, N 46 13'02.9”, E $18^{\circ} 25^{\prime}$ 52.1”, 320 m, 29.03.2015, leg. P. Erzberger, J. Deme, J. Csiky, det. P. Erzberger (B-Erzberger 19699). Villány Mts (0175.2) Com. Baranya. In terra in apricis montis Tenkes prope pag. Máriagyüd, $330 \mathrm{~m}, 07.08 .1999$, leg. B. Papp sub Fissidens bryoides BP 166595. Tiszántúl (8292.4) Comit. Hajdú-Bihar. In silva Tilos-erdő prope pag. Újszentmargita. Solo natronato. 28.03.1974, leg. S. Orbán sub Fissidens bryoides var. intermedius BP 154657. Northern Plain (8002.2) Comit. Szatmár. In silva Ricsei-erdő prope Turricse, $110 \mathrm{~m}, 22.05 .1960$, leg. Á. Boros (as admixture to F. taxifolius) BP 93573. Dráva-sík (0070.3) Somogy County, Barcs, on soil near the Dráva bank, N 45 56' 21.1", E $17^{\circ} 24^{\prime} 14.4^{\prime \prime}, 100$ m, 30.09.2015, leg. P. Erzberger, Cs. Németh and A. Mesterházy (B-Erzberger 20653).

The map is still very incomplete, since this species has been often overlooked as F. bryoides. Some records of "F. viridulus" based on sterile specimens might include $F$. incurvus.

Distribution in adjacent countries: Reported from all countries surrounding Hungary; red-listed in Austria (4, risk assumed), Slovenia (EN), and Slovakia (VU) (HodgetTs 2015).

Literature: Boros (1968) reports this taxon as F. bryoides var. viridulus from the Börzsöny Mts, Kőszeg Mts, Mecsek Mts, and Northern Plain. The presence of $F$. viridulus in these regions is confirmed in this revision (see above).

Note on taxonomic status: According to Bruggeman-Nannenga in Hill et al. (2006), " $F$. viridulus is treated by North American authors as an expression of F. bryoides" (Ann. 105).

Red list status: NT (PAPP et al. 2010); according to the present state of knowledge, LC appears appropriate.

\section{DISCUSSION}

\section{Evaluation of the revision}

In this study, sixteen species of the genus Fissidens are accepted as members of the Hungarian bryoflora, the same number as in the latest check-list (PAPP 
et al. 2010). However, two species (F. crispus, F. bambergeri) are newly reported from Hungary, whereas two others (F. curnovii, F. crassipes subsp. warnstorfii) are excluded or no longer considered, respectively.

\section{Taxonomic considerations}

The number of taxa is inevitably affected by the taxonomic concepts adopted in this study, which differ in some respects from the taxonomy of the most recent European checklists (Hill et al. 2006, HodgetTs 2015).

I consider F. bambergeri sufficiently characterised by the morphological features used traditionally and in accordance with e.g. AHRENS (2000), MEINUNGER and SCHRÖDER (2007), to warrant its recognition as a separate entity different from $F$. viridulus. If $F$. intralimbatus Ruthe is interpreted to be conspecific with $F$. bambergeri, then the latter is not new to Hungary, but it was recognised already by Boros in 1951 (see the specimen BP 94238 from Bükk Mts).

F. curnovii is excluded from the Hungarian bryoflora, the corresponding specimen is revised to F. bryoides var. bryoides. Here I follow Hill et al. (2006) and GUERRA and EDERRA (2015) and treat F. curnovii as a variety of F. bryoides: F. bryoides var. caespitans.

Also in accordance with GUERRA and EDERRA (2015) I do no longer distinguish between $F$. crassipes subsp. crassipes and $F$. crassipes subsp. warnstorfi, since the characters used traditionally to make this distinction appear highly variable and do not allow a precise delimitation. Nevertheless, a profound biosystematic study of the complex is desirable.

In the case of $F$. exiguus, which is not accepted by Bruggeman-Nannenga in Hill et al. (2006), I provisionally retain this name until further studies resolve the question whether these plants are only poorly limbate expressions of $F$. pusillus (or F. viridulus), or some kind of independent taxon. However, the view of Bruggeman-Nannenga is to some extent confirmed by my observations of such poorly limbate forms of F. pusillus (Fig. 17E, F, G).

In some cases there are indications that an established name may cover more than one taxon.

MEINUNGER and SCHRÖDER (2007) suggested that plants with the characters of F. gymnandrus, in particular with naked axillary antheridia, but growing in other than riverine habitats, might represent a different taxon. They emphasised that they often found a single, narrow bract together with the antheridia in riverine $F$. gymnandrus, but this structure was never found in plants from other habitats. I also found often a single bract or sometimes also a pair of bracts next to the antheridia of F. gymnandrus in riverine habitats (see Fig. 23M, N, O), but I recorded also many riverine populations without this structure. Therefore, I 
think that this is not a constant feature, and its lack does not imply that a taxon different from F. gymnandrus is at hand. KöCKINGER et al. (2008: 284) reported F. gymnandrus also from other than riverine habitats. Z. Hradilek (pers. comm.) puts forward the hypothesis that plants with naked axillary antheridia from calcareous habitats (growing on bare, obviously decalcified soil) represent a taxon different from $F$. gymnandrus. Further studies seem necessary to elucidate this question and the taxonomic value of the bract.

The possible incongruence of the concepts of British and continental authors concerning $F$. pusillus as evident from its ecological affinities has already been mentioned in the Introduction. There are also morphological indications pointing in the same direction: SMITH (2004: 246) describes an intralaminar limbidium in F. pusillus, but according e.g. to GUERRA and EDERRA (2015: 159), F. pusillus does not posses an intralaminar limbidium. These same authors describe the limbidium of F. pusillus as unistratose, whereas SMITH characterises it as 1-3-stratose.

However, these character states, an intralaminar and pluristratose limbidium, are found in F. crassipes. As SMITH - in my opinion correctly - points out, "there is a complete intergradation from large aquatic forms, approaching $F$. crassipes in size, to smaller plants on both aquatic and terrestrial rocks" (SMITH 2004: 246). It appears to me that British authors possibly draw the line of distinction at a different point, thus including some $F$. crassipes-like forms in their concept of $F$. pusillus.

There are several specimens that key out as F. pusillus but in my opinion do not belong to this species, among other reasons since they differ fundamentally in their substrate: calcareous rocks. These specimens have been listed separately and are not included in the map for F. pusillus. A biosystematic study of F. pusillus and related taxa is needed to establish the identity of these specimens and to resolve the question whether the British concept of $F$. pusillus covers more than one taxon. Related to this question are the difficulties encountered in some cases to distinguish between $F$. pusillus and $F$. gracilifolius.

In this revision, not all specimens could be definitely named, in particular collections from caves (about 15 specimens) could not be identified by morphological methods, since they displayed several untypical features.

Frequency and red list categories of Fissidens species in Hungary

(Fig. 36, Table 1)

The frequency of individual Fissidens species is obviously related to the availability of suitable substrates and growth sites for the species in the country. The most frequent species are F. taxifolius, F. dubius, and F. bryoides, together covering 
more than half of all grid cell data. These species find suitable conditions in many types of shaded (forest: F. taxifolius, F. bryoides) or open (grasslands, basic rock: F. dubius) situations. The group of species of intermediate frequency consists of species with more selective habitat requirements: $F$. gracilifolius and $F$. pusillus grow on different kinds of moist or wet, shaded rock (calcareous and siliceous, respectively), F. adianthoides is a wetland species, F. crassipes, F. gymnandrus, and $F$. arnoldii are restricted to watercourses of different size and surrounding vegetation, and F. exilis, F. viridulus, F. incurvus, and F. bambergeri are soil dwellers with different needs concerning soil $\mathrm{pH}$, moisture and shade. Finally, the most rare members of the genus (F. crispus, F. curvatus, F. exiguus) were collected only once in the past in one grid cell (1-2 growth places) each, and information on their special ecological needs is scarce, nor do we know if their populations still exist in the country. In the case of F. curvatus, where several searches at the old location were unsuccessful, we must assume that the species has vanished.

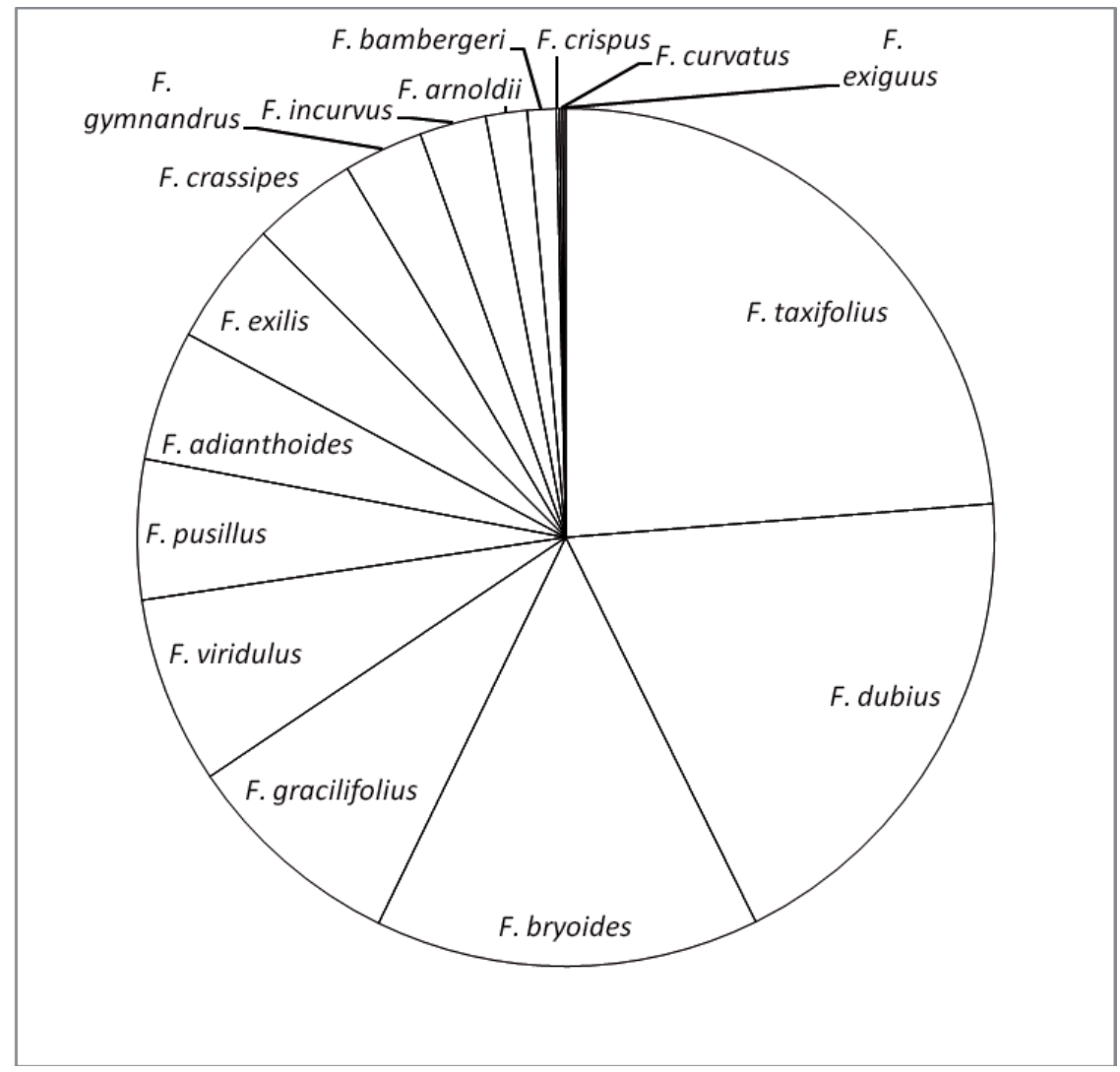

Fig. 36. Frequency of Fissidens taxa in Hungary (number of grid cells). 
Table 1. Frequency and red list categories of Fissidens species in Hungary (Abbreviations of red list categories (PAPP et al. 2010): $\mathrm{DD}=$ data deficient; $\mathrm{DD}$-va = data deficient vanished; $\mathrm{CR}=$ critically endangered; $\mathrm{EN}=$ endangered $; \mathrm{VU}=$ vulnerable; $\mathrm{NT}=$ near threatened $; \mathrm{LC}=$ least concern; LC-att $=$ least concern attention).

\begin{tabular}{lccccc}
\hline Species & \multicolumn{3}{c}{ Number of grid cells } & \multicolumn{2}{c}{ Red list status } \\
\cline { 2 - 6 } & total & $\begin{array}{c}\text { recent (af- } \\
\text { ter 1973) }\end{array}$ & $\%$ recent & PAPP et al. (2010) & proposed \\
\hline F. adianthoides & 41 & 10 & 24.4 & NT & VU \\
F. arnoldii & 13 & 6 & 46.2 & VU & VU \\
F. bambergeri & 9 & 6 & 66.7 & - & VU \\
F. bryoides & 121 & 63 & 52.1 & LC & LC \\
F. crassipes & 33 & 20 & 60.6 & LC & LC \\
F. crispus & 1 & 0 & 0 & - & DD \\
F. curvatus & 1 & 0 & 0 & DD-va & DD-va \\
F. dubius & 158 & 102 & 64.6 & LC & LC \\
F. exiguus & 1 & 0 & 0 & EN & DD \\
F. exilis & 39 & 26 & 66.7 & NT & LC \\
F. gracilifolius & 70 & 36 & 51.4 & LC-att & LC \\
F. gymnandrus & 25 & 25 & 100.0 & DD & NT \\
F. incurvus & 21 & 10 & 47.6 & EN & NT \\
F. pusillus & 44 & 36 & 81.8 & LC & LC \\
F. taxifolius & 198 & 140 & 70.7 & LC & LC \\
F. viridulus & 59 & 43 & 72.9 & NT & LC \\
total & 834 & & & & \\
\hline & & & & & \\
\hline
\end{tabular}

According to the present state of knowledge, 8 species of Fissidens are in the category LC, among them two (F. exilis and F. viridulus) were previously rated NT. Two species are considered NT, which were previously DD (F. gymnandrus) and EN ( $F$. incurvus), respectively. Three species are VU, among them the newly reported $F$. bambergeri, and $F$. arnoldii, which was already in this category; however, F. adianthoides was previously considered NT. At present, none of the Fissidens species is considered EN or CR, but for three species the data are insufficient for red list assessment, these are DD, among them the newly reported F. crispus and the long-known $F$. exiguus, as well as F. curvatus, which is unchanged as DD-va.

Acknowledgements - Thanks are due to the curators of the bryophyte collections of $\mathrm{BP}, \mathrm{B}$ and JE for loan of specimens, to Th. Homm (Elsfleth, Germany), for examining some critical specimens 
and interesting discussions, to Z. Hradilek (Olomouc-Holice, Czech Republic), for the exchange of interesting views. I also express my sincere thanks to B. Papp for her constructive criticism of the manuscript, to Cs. Németh for the preparation of the distribution maps and the translation of the abstract, to Julia Baudier for help with the figures, and to H. Kürschner (Berlin), for the loan of drawing apparatus. Participation in field work, and contribution of specimens or data by K. Baráth, J. Csiky, J. Deme, A. Kausits, J. Kis, A. Kovács, D. Kovács, A. Mesterházy, J. Nagy, Cs. Németh, B. Papp, T. Pócs, P. Szücs are gratefully acknowledged.

Összefoglaló: Az MTM Növénytár, valamint a szerző saját gyüjteményében található, Magyarország teljes területére nézve reprezentatívnak tekinthető, összesen mintegy 1500 kapszulányi Fissidens herbáriumi példány revideálása során 16 faj elöfordulását sikerült kimutatni. Közülük 14 (F. adianthoides, F. arnoldii, F. bambergeri, F. bryoides var. bryoides, F. crassipes, F. crispus ( $=$ F. limbatus), F. curvatus (= F. algarvicus), F. dubius, F. exiguus, F. exilis, F. gracilifolius, F. gymnandrus, F. incurvus, F. pusillus, F. taxifolius, F. viridulus) már korábban is ismert volt az ország területéről, míg 2 faj (F. bambergeri, F. crispus) újnak bizonyult a magyar mohaflórára. Mivel a F. crassipes két alfajának (subsp. warnstorfii és subsp. crassipes) további elkülönítése nem megalapozott, a $F$. bryoides var. caespitans $(=F$. curnovii) hazai adata pedig törlendő, az aktuális checklist-en szereplő Fissidens taxonok száma összességében nem változott. Habár a $F$. bambergeri és a $F$. exiguus taxonómiai megítélése némiképp vitatott, egyelőre nem tünik indokoltnak faji rangjuk elvetése sem. Jelen munka, határozókulccsal, illusztrációkkal és elterjedési térképekkel kiegészítve tartalmazza valamennyi Magyarországról előkerült Fissidens taxon részletes leírását, élőhelyi és ökológiai jellemzőit, valamint természetvédelmi vonatkozásait. Továbbá leírásokat (esetenként illusztrációkkal kiegészítve) közöl a környező országokban előforduló, Magyarországon mostanáig nem észlelt, de potenciálisan várható fajokról is (F. fontanus, F. osmundoides, F. ovatifolius, F. rivularis, F. rufulus, F. serrulatus). Ez utóbbiak esetleges detektálását segítheti a közölt határozókulcsban való szerepeltetésük is.

\section{REFERENCES}

Ahrens, M. (2000): Fissidentaceae, Spaltzahnmoose. - In: Nebel, M. and Philippi, G. (eds): Die Moose Baden-Württembergs, Band 1. Ulmer, Stuttgart, pp. 99-128.

Ahrens, M. and HARMs, K. H. (2002): Zum Vorkommen und zur Ökologie von Fissidens rivularis (Bryopsida) im Nordschwarzwald. - Carolinea 60: 75-81.

Allen, B., Pursell, R. A. and Darigo, C. (2004): Fissidens exilis and a key to the species of Fissidens in Missouri. - Evansia 21: 111-115.

Atherton, I., Bosaneuet, S. and Lawley, M. (eds) (2010): Mosses and liverworts of Britain and Ireland - a field guide. - British Bryological Society, Plymouth, 848 pp.

Beever, J., Malcolm, B. and Malcolm, N. (2002): The moss genus Fissidens in New Zealand. An illustrated key. - Micro-Optics Press, Zew Zealand, 91pp. + CD-Rom.

BijLsma, R. J. (2000): Het Verdwenen riviervedermos (Fissidens rufulus) na 100 jaar weer boven water. - Buxbaumiella 53: 44-45.

Bizot, M. and Pierrot, R. B. (1964): Observations sur quelques espèces du genre Fissidens (II): Fissidens valiae P. de la V., espèce nouvelle pour la France. - Rev. Bryol. Lichénol. 33: 230-234.

Blockeel, T. L., Bosanguet, S. D. S., Hill, M. O. and Preston, C. D. (2014): Atlas of British and Irish bryophytes. The distribution and habitats of mosses and liverworts in Britain and Ireland. Vol. 2. - Pisces Publications on behalf of the British Bryological Society, Newbury, 652 pp.

Boros, Á. (1951): Bryologische Beiträge zur Kenntnis der Flora von Ungarn und der Karpaten. Acta Biol. 2: 369-409. 
Boros, Á. (1953): Magyarország mohái. - Akadémiai Kiadó, Budapest, 360 pp.

Boros, Á. (1968): Bryogeographie und Bryoflora Ungarns. - Akadémiai Kiadó, Budapest, 466 pp.

Bruggeman-Nannenga, M. A. (1982): The section Pachylomidium (genus Fissidens) III. The F. crassipes-subcomplex (F. bryoides-complex), F. sublinearifolius (Pot. Varde) Brugg.-Nann. and F. fluitans (Pot. Varde) Brugg.-Nann. - Proc. Koninkl. Nederland. Akad. Wetensch., Ser. C 85(1): 59-104.

Bruggeman-Nannenga, M. A. (1985): The section Pachylomidium (genus Fissidens). IV. Further species from Europe, the Mediterranean and the Atlantic African islands. - Proc. Koninkl. Nederl. Akad. Wetensch. Serie C 88: 183-207.

Bruggeman-NANnenga, M. A. (1990): On the anatomy of the costa in Fissidens. - Tropical Bryol. 3: 37-44.

Bruggeman-Nannenga, M. A. (1989): Fissidens. - In: Touw, A. and Rubers, W. V. (eds): De Nederlandse Bladmossen. Flora en verspreidingsatlas van de Nederlandse Musci (Sphagnum uitgezonderd). Stichting Uitgeverij Koninklijke Nederlandse Natuurhistorische Vereniging, Utrecht, pp. 77-89.

Bruggeman-NANnenga, M. A. and Berendsen, W. (1990): On the peristome types found in the Fissidentaceae and their importance for the classifications. - J. Hattori Bot. Lab. 68: 193-234.

Bruggeman-Nannenga, M. A. and Pursell, R. A. (1995): Notes on Fissidens V. - Lindbergia 20: 49-55.

Casas, C., Brugués, M. and Cros, R. M. (2001): Flora dels briòfits dels Països Catalans. I. Molses. - Institut d'Estudis Catalans, Barcelona, 278 pp.

Casas, C., Brugués, M., Cros, R. M. and Sérgio, C. (2006): Handbook of mosses of the Iberian Peninsula and the Balearic Islands. - Institut d'Estudis Catalans, Barcelona, $349 \mathrm{pp}$.

Corley, M. F. V. (1980): The Fissidens viridulus complex in the British Isles and Europe. - J. Bryol. 11: 191-208. http://dx.doi.org/10.1179/jbr.1980.11.2.191

Corley, M. F. V., Crundwell, A. C., Düll, R., Hill, M. O. and Smith, A. J. E. (1981): Mosses of Europe and the Azores; an annotated list of species, with synonyms from the recent literature. - J. Bryol. 11: 609-689. http://dx.doi.org/10.1179/jbr.1981.11.4.609

Cortini Pedrotti, C. (2001): Flora dei Muschi d'Italia. Sphagnopsida Andreaeopsida Bryopsida (I parte). - Antonio Delfino Editore medicina-scienzia, Roma, Milano, 817 pp.

Crum, H. A. and Anderson, L. E. (1981): Mosses of Eastern North America, Vol. 1. - Columbia University Press, New York, 663 pp.

DEGEN, Á. (1922): Bryológiai érdekességek Budapest Flórájában. (Über einige interessante bryologische Funde in der Umgebung von Budapest). - Magyar Bot. Lapok 21: 26-32.

Demaret, F. and Castagne, É. (1959): Bryophytes. Vol. 2. Fasc. 1. - In: Robyns, W. (ed.): Flore générale de Belgique. Bruxelles. Ministère de l'agriculture, Jardin botanique national de Belgique, Bruxelles, pp. 1-112.

ECCB (1995): Red data book of European bryophytes. - Committee for Conservation of Bryophytes, Trondheim, $291 \mathrm{pp}$.

ERzBERger, P. (2002): Minor contribution to the bryoflora of the Cserhát Mts (Hungary). - Studia bot. hung. 33: 41-45.

Erzberger, P. (2009): The genera Grimmia and Coscinodon (Grimmiaceae, Musci) in Hungary. - Studia bot. hung. 40: 37-124.

Erzberger, P. (2012): Project plan: bryophyte mapping of Hungary. - Program and Abstracts, 8th Conference of European Committee for Conservation of Bryophytes, Budapest, 18-21 April 2012, p. 12. 
ERzberger, P. (2016): Fissidens crispus Mont. Hungary. In: Ellis, L. T. (ed.): New national and regional bryophyte records, 48. - J. Bryol. 38 (in press)

http://dx.doi.org/10.1080/03736687.2016.1206685

ERZBERger, P., BEDNAREK-OCHYRA, H. and OChYRA, R. (2016): Grimmiaceae subfam. Racomitrioideae (Bryophyta) in Hungary. - Polish Bot. J. 61(1): 23-51.

http://dx.doi.org/10.1515/pbj-2016-0015

Erzberger, P., Németh, Cs., Papp, B., Mesterházy, A., Csiky, J. and Baráth, K. (2015): Revision of the red list status of Hungarian bryophytes 1 . New occurrences of species previously thought to be regionally extinct or without recent data. - Studia bot. hung. 46(2): 15-53. http://dx.doi.org/10.17110/studbot.2015.46.2.15

ERzBerger, P. and PAPP, B. (2004): Annotated checklist of Hungarian bryophytes. - Studia bot. bung. 35: 91-149.

ERzberger, P. and Schröder, W. (2008): The genus Schistidium (Grimmiaceae, Musci) in Hungary. - Studia bot. hung. 39: 27-88.

ERzBerger, P. and Schröder, W. (2013): The genus Bryum (Bryaceae, Musci) in Hungary. Studia bot. hung. 44: 5-192.

Frey, W., Frahm, J.-P., Fischer, E. and Lobin, W. (2006): The liverworts, mosses and ferns of Europe. - Harley Books, Colchester, 512 pp.

Guerra, J. and Ederra, A. (2015): Fissidentaceae. - In: GuERrA, J. and BruguÉs, M. (eds): Flora Briofitica Iberica. Archidiales, Dicranales, Fissidentales, Seligeriales, Grimmiales. Vol. 2. Universidad de Murcia, Sociedad Española de Briología, Murcia, pp. 153-187.

Hill, M. O., Preston, C. D. and Smith, A. J. E. (1992): Atlas of the bryophytes of Britain and Ireland, Vol. 2. Mosses (except Diplolepideae). - Harley Books, Colchester, 400 pp.

Hill, M. O., Bell, N., Bruggeman-Nannenga, M. A., Brugués, M., Cano, M. J., Enroth, J., Flatberg, K. I., Frahm, J.-P., Gallego, M. T., Garilleti, R., Guerra, J., Hedenäs, L., Holyoak, D. T., Hyvönen, J., Ignatov, M. S., Lara, F., Mazimpaka, V., Muñoz, J. and SÖDERSTRÖM, L. (2006): An annotated checklist of the mosses of Europe and Macaronesia. - J. Bryol. 28: 198-267. http://dx.doi.org/10.1179/174328206x119998

HodgetTS, N. G. (2015): Checklist and country status of European bryophytes - towards a new red list for Europe. - Irish Wildlife Manuals 84: 1-124.

HolyoAK, D. T. and Whitehouse, H. L. K. (1998): Occurrence of Fissidens curnovii with brown, red and changeable rhizoid coloration. - J. Bryol. 20: 103-108.

Ignatov, M. S. and Afonina, O. M. (1992): Check-list of mosses of the former USSR. - Arctoa 1: 1-85. http://dx.doi.org/10.15298/arctoa.01.01

Ignatov, M. S., Afonina, O. M. and Ignatova, E. A. (2006): Check-list of mosses of East Europe and Asia. - Arctoa 15: 1-130.

IUCN (1978): The IUCN plant red data book. - International Union for the Conservation of Nature, Richmond.

Köckinger, H., Suanjak, M., Schriebl, A. and Schröck, C. (2008): Die Moose Kärntens. Sonderreihe Natur Kärnten 4, Verlag des Naturwissenschaftlichen Vereins für Kärnten, Klagenfurt, 319 pp.

Köckinger, H., Schröck, C., Krisai, R. and Zechmeister, H. G. (2011): Checklist of Austrian bryophytes. - http://131.130.59.133/projekte/moose/. (accessed: 25.01.2014)

KubinsKÁ A., JANOviCovÁ K. and Šoltés R. (2001): Aktualizovaný zoznam pečeňoviek, rožtekov a machov Slovenska. [Updated checklist of liverworts, hornworts and mosses of Slovakia]. - Bryonora 28: 4-10.

KuČera, J., VáŇa, J. and Hradílek, Z. (2012): Bryophyte flora of the Czech Republic: updated checklist and red list and a brief analysis. - Preslia 84: 813-850. 
Latzel, A. (1931): Vorarbeiten zu einer Laubmoosflora Dalmatiens. - Beih. Bot. Centralbl. 48: 437-512.

Limpricht, K. G. (1890): Die Laubmoose Deutschlands, Oesterreichs und der Schweiz. I. Abtheilung: Sphagnaceae, Andreaeaceae, Archidiaceae, Bryinae (Cleistocarpae, Stegocarpae [Acrocarpae]) (= Dr. L. Rabenhorst's Kryptogamenflora von Deutschland, Österrreich und der Schweiz 2. Aufl.). - Kummer, Leipzig, 836 pp.

Lim Pricht, K. G. (1904): Die Laubmoose Deutschlands, Oesterreichs und der Schweiz. Unter Berücksichtigung der übrigen Länder Europas u. Sibiriens. III. Abtheilung: Hypnaceae u. Nachträge, Synonymen-Register u. Litteratur-Verzeichnis. - Kummer, Leipzig, 864 pp. +79 pp.

Magill, R. E. (ed.) (1990): Glossarium Polyglottum Bryologiae. - Missouri Botanical Garden Press, St Louis, $297 \mathrm{pp}$.

MARTinčič, A. (2003): Seznam listnath mahov (Bryopsida) Slovenije. - Hacquetia 2(1): 91-166.

MARTINČIČ, A. (2016): Updated red list of bryophytes of Slovenia. - Hacquetia 15(1): 107-126.

MeINUNGeR, L. and SCHRöDER, W. (2007): Verbreitungsatlas der Moose Deutschlands, Vol. 2. - Hrsg. von O. Dürhammer für die Regensburgische Botanische Gesellschaft, Regensburg, 699 pp.

MönKeMEYeR, W. (1927): Dr. L. Rabenhorsts Kryptogamen-Flora von Deutschland, Österreich und der Schweiz, Vierter Band, Ergänzungsband: Die Laubmoose Europas Andreaeales - Bryales. Akademische Verlagsgesellschaft, Leipzig, 956 pp.

Müller, F. and Pursell, R. A. (2003): The genus Fissidens (Musci, Fissidentaceae) in Chile. $-J$. Hattori Bot. Lab. 93: 117-139.

Niklfeld, H. (1971): Bericht über die Kartierung der Flora Mitteleuropas. - Taxon 20: 545-571. http://dx.doi.org/10.2307/1218258

Nyнolm, E. (1987): Illustrated flora of Nordic mosses. Fasc. 1. Fissidentaceae Seligeriaceae. - Nordic Bryological Society, Copenhagen and Lund, 72 pp.

Orbán, S. and VAJdA, L. (1983): Magyarország mohaflórájának kézikönyve. - Akadémiai Kiadó, Budapest, $518 \mathrm{pp}$.

PAPp, B. (2009): The bryophyte flora of the Aggtelek National Park. - In: PAPP, B. (ed.): The Flora of the Aggtelek National Park. Cryptogams. Hungarian National History Museum, Budapest, pp. 175-230.

PApp, B. and ERzBerger, P. (2003): Data about the actual local populations of bryophyte species protected in Hungary. - Studia bot. hung. 34: 33-42.

Papp, B., ErZberger, P., Ódor, P., Hock, Zs., Szövényi, P., SzUrdoki, E. and Tóth, Z. (2010): Updated checklist and red list of Hungarian bryophytes. - Studia bot. hung. 41: 31-59.

PAPP, B., ÓDOR, P. and ERZBERGER, P. (1999-2000): Preliminary data about the present Hungarian local populations of rare European bryophytes. - Studia bot. hung. 30-31: 95-111. (19992000).

PAPP, B. and RAJCZY, M. (1997): Bioindication of habitat conditions with bryophytes at some streams in Aggtelek National Park and Balaton-felvidék region, Hungary. - In: Tótн, E. and Horváth, R. (eds): Proceedings of "Research, Conservation, Management" Conference, Aggtelek, Hungary, 2: 47-57.

Pursell, R. A. (1994a): Fissidentaceae. - In: Allen, B., Crum, H., Pursell, R. A., Allen, N. S. and ReEsE, W. D. (eds): Moss Flora of Central America. Vol. 1. Sphagnaceae-Calymperaceae. Missouri Botanical Garden Press, St Louis, pp. 40-80.

Pursell, R. A. (1994b): Fissidentales. In: Sharp, A. J., Crum, H. A. and Eckel, P. M. (eds): The Moss Flora of Mexico. Vol. 1. Sphagnales to Bryales. - Mem. New York Bot. Garden 69: 31-81.

PURSell, R. A. (2007): Fissidentaceae Schimper. - In: Flora of North America Editorial Committee (eds): Flora of North America, Vol. 27, Bryophytes: Mosses, part 1. Oxford University Press, New York, pp. 331-357. 
Pursell, R. A. and Bruggeman-NANnenga, M. A. (2004): A revision of the infrageneric taxa of Fissidens. - Bryologist 107: 1-20.

http://dx.doi.org/10.1639/0007-2745(2004)107[1:arotit]2.0.co;2

Ros, R. M., Mazimpaka, V., Abou-Salama, U., Aleffi, M., Blockeel, T. L., Brugués, M., Cros, R. M., Dias, M. G., Dirkse, G. M., Draper, I., El-Saadawi, W., ErdaĞ, A., Ganeva, A., Gabriel, R., González-Mancebo, J. M., Granger, C., Herrnstadt, I., Khalh, K., Kürschner, H., Losada-Lima, A., Luís, L., Mifsud, S., Privitera, M., Puglisi, M., Sabovljević, M., Sérgio, C., Shabbara, H., Sim-Sim, M., Sotiaux, A., Tacchi, R., Vanderpoorten, A. and Werner, O. (2013): Mosses of the Mediterranean, an annotated checklist. - Cryptogamie, Bryologie 34: 99-283. http://dx.doi.org/10.7872/cryb.v34.iss2.2013.99

Sabovljević, M., Natcheva, R., Dihoru, G., Tsakiri, E., Dragićević, S., ErdaĞ, A. and PAPP, B. (2008): Check-list of the mosses of SE Europe. - Phytol. Balcan. 14: 207-244.

Sesterhenn, G. (1998): Erstnachweis von Fissidens monguillonii in Deutschland. - Herzogia 13: 53-62.

Sмith, A. J. E. (2004): The moss flora of Britain and Ireland, 2nd ed. - Cambridge University Press, Cambridge, $1012 \mathrm{pp}$.

ŞTEFĂNUȚ, S. and Goin, I. (2012): Checklist and red list of Bryophytes of Romania. - Nova Hedwigia 95: 59-104. http://dx.doi.org/10.1127/0029-5035/2012/0044

SzÜCs, P., SCHмidt, D. and CsISzÁR, Á. (2015): Kiegészítések a Soproni-hegység mohaflórájához II. (Contribution to the bryoflora of Sopron Hills (W Hungary) II). - Kitaibelia 20: 59-66. http://dx.doi.org./10.17542/kit.20.59)

Touw, A. and Rubers, W. V. (eds) (1989): De Nederlandse Bladmossen. Flora en verspreidingsatlas van de Nederlandse Musci (Sphagnum uitgezonderd). - Stichting Uitgeverij Koninklijke Nederlands Natuurhistorische Vereniging, Utrecht, $532 \mathrm{pp}$.

VAJDA, L. (1956): Fissidens algarvicus Solms-Laubach aus dem Börzsöny-Gebirge (Mittelungarn). - Ann. Mus. Nat. Hung. 7: 299-301.

Vajda, L. (1958): Fissidens košaninii Latzel dans la Montagne Börzsöny en Hongrie. - Rev. Bryol. Lichénol. 27: 49-51.

VAJDA, L. (1975): Bryologische Notizen IV. - Studia bot. hung. 10: 119-122.

(submitted: 24.04.2106, accepted: 01.06.2016) 